Гарус Я.Н., Данаева М.М.

\title{
КОМПЛЕКСНОЕ ЛЕЧЕНИЕ ПЕРИОДОНТИТОВ С ПРИМЕНЕНИЕМ СВЕТОТЕРАПИИ
}

Ставрополь - 2011 
УДК: 616-08:616.314.17-008.1 : 615.831

ББК: $56.612 .13+53.543$

$\Gamma: 21$

Рецензенты: Сохов С.Т. доктор медицинских наук, профессор кафедры стоматологии общей практики и анестезиологии ФПДО МГМСУ

Шугайлов И.А. доктор медицинских наук, профессор, зав.кафедрой стоматологии РМАПО

Минздравсоцразвития России

Гарус Я.Н., Данаева М.М. Комплексное лечение периодонтитов с применением светотерапии. - Ставрополь: Изд-во СтГМА, 2011. - с.

ISBN

В монографии на основании клинико-экспериментальных данных описан новый способ лечения верхушечных периодонтитов поляризованным светом в сочетании с обработкой системы корневых каналов раствором велтосепта с ультразвуком и пломбированием их пастой, содержащей данный антисептик и нанодисперсный гидроксиапатит «Остеоиндуцин».

Проведено микробиологическое исследование влияния озвученного антисептика велтосепт на микрофлору корневых каналов, определена минимальная подавляющая концентрация.

Изучены цитохимические показатели у больных верхушечным периодонтитом в зависимости от метода лечения: светолечения поляризованным светом, физико-химических способов обработки макро- и микроканалов, а также от свойств пломбировочного материала.

Разработанный комплекс лечебных мероприятий апробирован и внедрен в стоматологическую практику, оценена эффективность его воздействия на процессы регенерации в периодонте в отдаленные сроки наблюдений.

Использование данного способа лечения верхушечных периодонтитов позволяет значительно сократить сроки лечения, уменьшить количество рецидивов, добиться регенерации костных структур в периодонте. 


\section{СПИСОК УСЛОВНЫХ СОКРАЩЕНИЙ}

БT - свет «Bioptron»

ВСП № 1 - паста велтосепт

ВСПОИ № 2 - паста велтосепт с остеоиндуцином

ГШ - - гуттаперчевые штифты

КБ - - катионные белки

Л - лимфоциты

МПК - минимальная подавляющая концентрация препарата

МПО - миелопероксидаза

Н - - нейтрофилы

ОВПСИ - острый верхушечный периодонтит в стадии интоксикации

ОВПСЭ - острый верхушечный периодонтит в стадии экссудации

OT - - отсроченный метод лечения

ОФВП - - острые формы верхушечных периодонтитов

ОХВГП - обострившийся хронический верхушечный гранулематозный периодонтит

ОХВГрП - обострившийся хронический верхушечный гранулирующий периодонтит

ОХВП - обострившийся хронический верхушечный периодонтит

PBC - раствор велтосепта

PXГ - раствор хлоргексидина

TP - - традиционный метод лечения

У3 - ультразвук

ЭВ - - «Эвгедент»

ЭК - - - эпителиальные клетки 


\section{ОГЛАВЛЕНИЕ}

СПИСОК УСЛОВНЫХ СОКРАЩЕНИЙ

ВВЕДЕНИЕ

\section{ГЛава 1. СОВРЕМЕННЫЕ АСПЕКТЫ ЛЕЧЕНИЯ ПЕРИОДОНТИТОВ (ОБЗОР ЛИТЕРАТУРЫ)}

1.1. Современное состояние вопроса этиологии и патогенеза верхушечных периодонтитов

1.2. Иммунологические аспекты патогенеза верхушечных периодонтитов

1.3. Этиопатогенетические основы терапии воспалительных заболеваний периодонта

1.4. Современные методы лечения верхушечных периодонтитов

1.5. Применение ультразвука для санации системы макро- и микроканалов при лечении острых и обострившихся хронических верхушечных периодонтитов

1.6. Биостимулирующий свет «Bioptron» в комплексном лечении острых и обострившихся хронических верхушечных периодонтитов 1.6.1. Результаты использования системы света «Bioptron» в клинической практике российских врачей

1.7. Современные материалы для пломбирования корневых

каналов зубов при верхушечных периодонтитах, применяемые в работе

\section{ГЛава 2. МАТЕРИАЛЫ И МЕТОДЫ ИССЛЕДОВАНИЯ}

2.1. Материалы и методы микробиологического исследования

2.1.1. Изучение микрофлоры корневых каналов зубов у больных с острыми явлениями в периодонте

2.1.2. Определение штаммов микроорганизмов, используемых в эксперименте

2.1.3. Определение минимальной подавляющей концентрации велтосепта на плотной питательной среде

2.1.4. Определение минимальной подавляющей концентрации велтосепта суспензионным методом

2.1.5. Определение эффективности сочетанного действия раствора велтосепта и ультразвука на микрофлору корневых каналов зубов у больных с острыми явлениями в периодонте

2.1.6. Определение эффективности биостимулирующего света «Bioptron» в сочетании с озвученным раствором велтосепта на микрофлору корневых каналов зубов у больных с острыми явлениями в периодонте 
2.2.1. Характеристика клинического материала и методик лечения острых и обострившихся хронических верхушечных периодонтитов различными лечебными комплексами с применением полихроматичного света «Bioptron» и без него

2.2.2. Дезинфицирующее средство - антисептик «Велтосепт»

2.2.3. Новый пьезо-скалер «Amdent US 30 D» - мировой лидер

ультразвуковой технологии

2.2.4. Биостимулирующий свет «Bioptron»

2.2.5. Эндодонтические пломбировочные материалы, стимулирующие остеогенез

2.2.6. Критерии клинической эффективности проводимого лечения

2.2.7. Рентгенологическое исследование альвеолярных отростков челюстей

2.3. Материалы и методы определения цитохимических показателей у больных с различными формами верхушечного периодонтита

2.3.1. Методика забора материала десневого желобка для оценки клеточного состава

2.3.2. Приготовление мазков и забор материала для определения активности ферментных систем полиморфноядерных лейкоцитов

2.3.3. Определение миелопероксидазы

2.3.4. Определение лизосомальных катионных белков

2.3.5. Определение кислой фосфатазы

2.3.6. Определение щелочной фосфатазы

2.4. Методы статистической обработки материала

\section{ГЛАВа 3. РЕЗУЛЬТАТЫ МИКРОБИОЛОГИЧЕСКИХ ИССЛЕДОВАНИЙ}

3.1. Результаты определения минимальной подавляющей концентрации

«Велтосепт» в опытах на плотных питательных средах

3.2. Результаты определения минимальной подавляющей концентрации «Велтосепта» суспензионным методом

3.3. Результаты изучения микрофлоры корневых каналов зубов у больных с верхушечными периодонтитами

3.4. Результаты определения эффективности сочетанного действия велтосепта и физических факторов на микрофлору корневых каналов зубов у больных с верхушечными периодонтитами

\section{ГЛАВа 4. РЕЗУЛЬТАТЫ ЛЕЧЕНИЯ ОСТРЫХ И ОБОСТРИВШИХСЯ ХРОНИЧЕСКИХ ВЕРХУШЕЧНЫХ ПЕРИОДОНТИТОВ ПОД ВОЗДЕЙСТВИЕМ РАЗЛИЧНЫХ ЛЕЧЕБНЫХ КОМПЛЕКСОВ С ПРИМЕНЕНИЕМ ПОЛЯРИЗОВАННОГО СВЕТА}




\section{«BIOPTRON»}

4.1.1. Клиническая характеристика и рентгенологические данные больных с острыми верхушечными периодонтитами в стадии интоксикации (ОВПСИ) до лечения (первая группа)

4.1.2. Ближайшие результаты лечения острых верхушечных периодонтитов в стадии интоксикации различными лечебными комплексами

4.1.3. Сравнительная оценка эффективности использования различных пломбировочных материалов при лечении острых периодонтитов в стадии интоксикации (ОВПСИ)

4.2.1. Клиническая характеристика и рентгенологические данные у больных с острыми периодонтитами в стадии экссудации (ОВПСЭ) до лечения (вторая группа)

4.2.2. Ближайшие результаты лечения острых периодонтитов в фазе экссудации с использованием ирриганта велтосепта, ультразвука (внутриканально) и света «Bioptron» и без них 4.2.3. Сравнительная оценка эффективности использования различных пломбировочных материалов при лечении ОВПСЭ 4.3.1. Клиническая характеристика и рентгенологические данные у больных с обострившимися хроническими верхушечными гранулирующими периодонтитами (ОХВГрП) до лечения (третья группа)

4.3.2. Ближайшие результаты лечения обострившихся хронических верхушечных гранулирующих периодонтитов различными лечебными комплексами

4.3.3. Сравнительная оценка эффективности воздействия на периодонт при ОХВП различных пломбировочных материалов

4.4.1. Клиническая характеристика и рентгенологические данные

у больных с обострившимися хроническими гранулематозными периодонтитами (ОХВГП) до лечения (четвертая группа)

4.4.2. Ближайшие результаты лечения ОХВГП с использованием ультразвука (внутриканально) и поляризованного света «Bioptron» и без них

4.4.3. Сравнительная оценка эффективности воздействия на периодонт при ОХВГП различных пломбировочных материалов

4.5. Изучение цитохимических показателей содержимого десневого желобка у больных с различными формами периодонтитов до и после воздействия комплексной терапии с применением света «Bioptron»

4.5.1. Клеточный состав содержимого десневого желобка до и после лечения острых верхушечных периодонтитов

4.5.2. Изучение активности ферментативных систем нейтрофилов у больных с острыми верхушечными периодонтитами

4.5.3. Клеточный состав содержимого десневого желобка до и после лечения у больных с различными формами обострившихся хронических верхушечных периодонтитов 
4.5.4. Изучение активности цитоэнзимохимических показателей нейтрофилов $\mathrm{y}$ больных $\mathrm{c}$ различными формами обострившихся хронических верхушечных периодонтитов

4.6. Отдаленные клинико-рентгенологические результаты лечения острых и обострившихся хронических периодонтитов под воздействием различных лечебных комплексов

4.7. Сравнительная характеристика отдаленных результатов лечения деструктивных форм ОХВП по данным рентгенограмм с применением периапикального индекса PAI

Глава 5. ЗАКЛЮЧЕНИЕ

ВЫВОДЫ

ПРАКТИЧЕСКИЕ РЕКОМЕНДАЦИИ 


\section{ВВЕДЕНИЕ}

Актуальность исследования. Заболеваемость периодонта является на современном этапе терапевтической стоматологии одной из основных проблем, так как больные с различными формами периодонтита составляют $30 \%$ от общего числа обращающихся за помощью к стоматологу.

Среди многих причин, вызывающих заболевание периодонта, одно из первых мест отводится микроорганизмам и их токсинам. В результате проникновения микроорганизмов и их токсинов в периодонт, развивается острая воспалительная реакция, усиливающаяся за счет образования биологически активных веществ, влекущих сосудистую проницаемость, экссудацию, нарушение микроциркуляции кровообращения, и в результате деструкцию тканей периодонта, вызывая общую интоксикацию организма и могут осложняться одонтогенными воспалительными процессами челюстнолицевой области.

Традиционные методы лечения острых и обострившихся форм хронического периодонтита направлены на устранение микробного фактора (антимикробные и противовоспалительные средства). Но даже при соблюдении всех правил при лечении нередко возникают осложнения: болевые ощущения, отеки мягких тканей челюстно-лицевой области, появляющиеся после пломбирования каналов. Осложнения наблюдаются и при использовании современных методик пломбирования (пломбирование гуттаперчевыми штифтами, термофилами).

Целью консервативного эндодонтического лечения является разрушение и удаление микробной экосистемы, а также предотвращение повторного инфицирования. Несмотря на значительные усовершенствования эндодонтического инструментария и методик обработки, на сегодняшний день невозможно обеспечить полную дезинфекцию корневых каналов данными методами из-за сложной их внутренней анатомии, сложностью доступа традиционных инструментов и ирригационных растворов к 
бактериям, укрывшимся в труднодоступных участках корневых каналов. Необходим комплексный подход лечения периодонтитов с использованием инструментальных, медикаментозных, физических факторов, позволяющих активно влиять на основные звенья патогенеза околоверхушечного процесса, устранение воспалительно-деструктивного очага.

Нами принято решение изучить эффективность комплекса лечебных воздействий при лечении острых и обострившихся хронических верхушечных периодонтитов, состоящего из новейшего отечественного антисептика «Велтосепт», в сочетании с воздействием на микрофлору системы микроканалов ультразвуком и пломбированием их пастой, содержащей гидроксиапатит «Остеоиндуцин», а также принципиально нового лечения поляризованным светом лампы «Bioptron».

В качестве антисептика в комплекс лечебных воздействий включено новейшее средство с запатентованной комбинацией активных веществ широкого спектра действия микробиологической активности «Велтосепт» (Оренбург, Россия). «Велтосепт» широко применяется в хирургии, терапии, дерматологии, педиатрии, однако, применение его в стоматологии мало изучено, хотя препарат активен даже в отношении ВИЧ-инфекции и гепатита A.

Уникальным в многокомпонентности воздействия на внутреннюю среду корневых макро- и микроканалов является ультразвук. Ультразвук представляет собой механические колебания жидкой среды в канале с антисептиком, что приводит к сжатию и разрежению жидкой среды. В фазе растяжения происходит разрыв межмолекулярных сил сцепления и возникновения микрополостей - кавитация. Образующиеся при кавитации пузырьки в фазе сжатия мгновенно исчезают, а возникающие при этом ударные волны, электрические заряды и высокие локальные температуры, инициируют специфические звукохимические реакции в озвученной среде, где возникают мелко- и среднемасштабные течения и турбуляции, которые существенно ускоряют процессы растворения органических соединений. 
Кавитация и акустический поток оказывают повреждающее действие на клеточные оболочки бактерий.

Активный кислород, образующийся в процессе ультразвуковой обработки, является антагонистом анаэробов, тормозя рост популяций этих микроорганизмов.

Ультразвуковые колебания, создавая эффект кавитации, разрушают бактерии, механически очищают дентинные трубочки с наибольшей эффективностью. В этом случае не играет никакой роли ни форма канала, ни его диаметр, ни длина. Свет «Bioptron» излучает полихроматический свет в волновом диапазоне от 480 до 3400 нм, длина его волны выше, чем у УФизлучения, а энергетический диапазон ниже, чем у лазерного луча, поэтому он безвреден для организма. Свет, излучаемый лампой «Bioptron», линейно поляризован и движется в одном направлении в параллельных плоскостях, проникая на глубину 2,5-3 см, стимулирует регенеративные процессы, нормализует кровообращение, ликвидирует воспаление и отек тканей, ускоряет заживление ран, стимулирует обменные процессы и иммунные системы, обладает обезболивающим эффектом. Однако применение поляризованного света в стоматологии изучено недостаточно.

Нанодисперсный гидроксиапатит «Остеоиндуцин» на основе аморфного микрогранулята гидроксиапатита кальция с диаметром гранул 0,5-1 мкм и волокон, неплотно сформированных из этих же частиц, включенных в полисахаридную матрицу. Остеоиндуцин не имеет побочных продуктов и, как следствие, хорошо включается в процесс синтеза, оказывает стимулирующее действие на рост клеток, активирует остеосинтез, усиливает пролиферативную активность остеобластов и стимулирует процессы репаративного остеогенеза на месте введения, а также задерживает воспалительные процессы в костной ткани. Характеризуется биосовместимостью с организмом человека и не вызывает реакции отторжения. Применение его при лечении деструктивных форм периодонтитов не изучено. 


\section{ГЛАВА 1. \\ СОВРЕМЕННЫЕ АСПЕКТЫ ЛЕЧЕНИЯ ПЕРИОДОНТИТОВ (ОБЗОР ЛИТЕРАТУРЫ)}

\section{1. Современное состояние вопроса этиологии и патогенеза верхушечных периодонтитов}

Ученые различных стран мира в течение многих лет занимаются исследованием больных с патологией периодонта, что значительно обогатило знание этой проблемы на современном этапе развития стоматологии. Выявлены этиологические факторы, аспекты патогенеза заболевания, определены клинические, лабораторные и дифференциальнодиагностические признаки форм периодонтитов. Результаты исследований нашли широкое отражение в отечественной и зарубежной литературе.

На сегодняшний день заболевания периодонта занимают третье место по частоте обращаемости после кариеса и пульпита. Согласно данным ВО3 из-за болезней периодонта потеря зубов происходит гораздо чаще, чем по другим причинам. По происхождению верхушечный периодонтит может быть: инфекционный; травматический; медикаментозный. Инфекционный верхушечный периодонтит чаще всего возникает при проникновении в периодонт микроорганизмов.

Микрофлора корневых каналов разнообразна: стафилококки, стрептококки, диплококки, грамположительные и грамотрицательные палочки, бактероиды, фузобактерии, спирохеты, грибы рода Кандида. Микроорганизмы, вызывающие эндодонтические заболевания на 90\% состоят из облигатных анаэробов, и инфицируют не только мягкие ткани пульпы, но и главным образом пристеночный предентин корневого канала на глубину до 1-2 мм. В эндодонте с некротизированной пульпой обнаруживается до $10^{8}$ бактерий на 1 мл содержимого корневого канала. Рост анаэробной флоры с преобладанием грамотрицательных бактерий в корневых каналах очень интенсивен, так как в результате своей жизнедеятельности аэробные микроорганизмы поглощают весь кислород, что ведет к развитию анаэробов. Ассоциативная флора продуцирует 
ферменты и эндотоксины, которые препятствуют процессам хемотаксиса, фагоцитоза в периодонте. Проникновение микроорганизмов и их токсинов в периодонт обуславливает быстрое развитие воспалительного процесса. Вследствие повреждения оболочки грамположительных бактерий усиливается гиперемия и проницаемость сосудов, инфильтрация тканей лейкоцитами, макрофагами, усиливается экссудация, способствуя повышению внутрипериодонтального давления. Вследствие затрудненного оттока экссудата через корневой канал развивается острый воспалительный процесс.

Под влиянием инфекционных токсинов в периодонте развивается острое или хроническое воспаление, которое проявляется местно в области причинного зуба или захватывает область нескольких зубов и окружающие мягкие ткани. При снижении резистентности организма и малой интенсивности действия раздражителя процесс приобретает первично хронический характер. При остром гнойном периодонтите наблюдается отек и инфильтрация тканей клеточными элементами, аутолиз тканей с образованием абсцессов или диффузного гнойного пропитывания тканей периодонта. На прилегающих участках наблюдается остепластическое рассасывание костной ткани альвеолы и гнойная инфильтрация костномозговых пространств.

Одонтогенные воспалительные очаги обычно приводят к деструктивным изменениям периапикальных тканей и сопровождаются очагами инфекции, общей интоксикацией организма и могут осложняться одонтогенными воспалительными процессами челюстно-лицевой области. Приняв хроническое течение, воспалительный процесс после постоянного инфицирования периодонта, в его тканях происходят сложные процессы перестройки: расширение периодонтальной щели с преобладанием грубоволокнистой, бедной клетками ткани, новообразованием цемента и костной ткани наряду с разрушением и распадом мягких и твердых тканей при гранулематозном и гранулирующем периодонтите. Хронический процесс в 
периодонте поддерживается за счет наличия в корневых каналах зубов инфекционно-токсического содержимого, которое приводит к частым обострениям процесса.

\section{2. Иммунологические аспекты патогенеза верхушечных периодонтитов}

В последнее время установлено, что даже при наличии обширных периапикальных изменений, бактерии в подавляющем большинстве находятся в системе корневых каналов и если и обнаруживаются за верхушкой корня, то редко и в незначительных количествах. Поэтому причиной патологических изменений в периодонте и окружающей экстрарадикулярной ткани следует считать, главным образом, патогенные действия продуктов распада внутрикорневых бактерий. Поврежденные оболочки грамположительных бактерий выделяют эндотоксины, оказывающие антигенное воздействие на иммунную систему периодонта, токсически действуя на фибробласты, способствуя тканевой дистрофии и некрозу тканей периодонта, формируется вторичный иммунодефицит, характеризующийся угнетением Т-системы иммунитета и дисфункцией фагоцитарных клеток, нейтрофильных гранулоцитов, инфильтрацией тканей полиморфноядерными лейкоцитами, изменением реологических свойств крови.

Апикальный периодонтит представляет собой иммунный ответ на непрерывное разрушение антигенами периапикальных тканей, характеризующийся образованием гранулем при трансформации острого воспаления в хроническое.

По литературным данным в патогенезе хронического периодонтита имеет место два типа иммунных реакций. Первый тип реакций характеризуется образованием комплекса антиген - антитело, где $\lg \mathrm{E}$ является основным фактором формирующим атопическую реакцию: в результате постоянно поступающих из корневых каналов антигенов, которые связываются с двумя молекулами $\lg$ на поверхности базофилов и тучных 
клеток, из клетки высвобождается гистамин, серотонин и другие медиаторы воспаления, способствующие повышению проницаемости сосудов и увеличению миграции из них лейкоцитов, ферментов, которые разрушают ткани и способствуют остеопорозу костной ткани в периапикальной области. Второй тип реакции - гиперчувствительность замедленного действия, при которой с поступающим антигеном из корневых каналов реагирует сенсибилизированный Т-лимфоцит. $\mathrm{B}$ результате стимулируется размножение лимфоцитов и выделение лимфокинов, которые разрушают клетки периодонта, а макрофаги и нейтрофилы выделяют фермент коллагеназу, способствующую растворению коллагеновых волокон, вызывая деструкцию костной ткани.

Таким образом, в патогенезе верхушечного периодонтита реакция гиперчувствительности замедленного типа является одним из механизмов борьбы с чужеродными антигенами, формируя вторичный иммунодефицит, характеризующийся образованием гранулем.

\section{3. Этиопатогенетические основы терапии воспалительных заболеваний периодонта}

Терапевтическая задача при лечении острого и обострившегося верхушечных периодонтитов представляет собой устранение или существенное сокращение инфицирования корневых каналов, оказания противовоспалительного действия на ткани периодонта и восстановление очагов деструкции.

Успех эндодонтического лечения зависит от тщательности очистки корневого канала и надежности обтурации, что практически невозможно без инструментальной обработки. Но сложное и непредсказуемое анатомическое строение системы корневых каналов и обработка их только механическими методами не допустимы и бесперспективны, хотя инструментальная обработка корневых каналов включает в себя удаление некротизированных тканей, при этом происходит количественное сокращение микрофлоры и устранение продуцируемых ими токсических продуктов. 
При применении медикаментозной обработки системы макро- и микроканалов, учитывается активность препаратов в отношении микрофлоры, безопасность их применения для периодонта. В качестве противомикробных препаратов для лечения верхушечных периодонтитов используются антисептики, антибиотики, препараты-дезинфектанты, дерматотропные, растительные средства и другие. Антисептики нашли самое широкое распространение, они используются для медикаментозной обработки каналов и других воспалительных заболеваниях челюстнолицевой области.

Механизм действия различных препаратов, обладающих антисептическими свойствами разноплановый и может быть связан с денатурацией белка, разрушением гликозидных и пептидных связей в молекуле стенки бактерий, водородных связей, других структур бактериальной клетки, нарушением проницаемости мембраны, торможением активности бактериальных ферментов и др.

Применение в эндодонтии антисептиков различных фармакологических групп показало, что одни из них имеют низкую бактериальную активность (перекись водорода, препараты нитрофуранового ряда и др.), другие оказывают раздражающее, аллергическое, тератогенное, мутагенное действие (группа фенолов, этиловый спирт, хлоргексидин, диоксидин, карболовая кислота, трикрезол).

Было установлено, что антисептики из группы окислителей, галогенов, поверхностно-активных веществ эффективны, но их действие кратковременно. Продолжается применение антибиотиков и сульфаниламидов, оказывающих специфическое антимикробное действие. Однако их применение ограничивается возможными нежелательными последствиями (угнетение процессов пролиферации, фагоцитарной и иммунобиологической активности, отсутствие репаративной активности). Местное лечение антибиотиками не всегда приносит успех при лечении периодонтита, что связано, с одной стороны, с устойчивостью микрофлоры к 
антибиотикам, с другой - отрицательным влиянием на состояние компенсаторно-приспособительных реакций организма. Поэтому антибиотики сочетают с другими препаратами, чаще всего с антисептиками и кортикостероидами.

Клинические наблюдения применения ципрофлоксацина, метранидозола показали эффективность купирования инфекционного процесса в периодонте.

В литературе имеются сведения о положительном опыте применения гормональных препаратов (гидрокортизон, преднизолон) в сочетании с антисептиками или антибиотиками. Но кортикостероиды имеют ряд отрицательных характеристик: они угнетают фагоцитоз, задерживая развитие грануляции, блокируют выработку антител, ослабляют иммунологические свойства пораженных тканей, задерживая синтез коллагена и процессы рубцевания. Поэтому стероидная терапия при деструктивных процессах в периодонте нецелесообразна.

Описана энзимотерапия, основанная на избирательном действии протеолетических ферментов на некротические ткани и растворение вязкого секрета в корневом канале (энзимол, трипсин, химотрипсин и др.).

С целью усиления антимикробных свойств ферменты сочетают с антибиотиками. При деструктивных процессах в периодонте применяют иммобилизованные формы трипсина (ПАСК-трипсин, кальцекс-трипсин).

Имеются данные о положительном опыте применения препаратов растительного и животного происхождения: лизоцима, пентоксила, сангвиритрина и др. при лечении острых и обострившихся форм верхушечных периодонтитов. Экспериментальным путем доказано, что заверхушечное введение лизоцим-витаминной пасты приводит к созреванию грануляционной ткани в зоне деструкции, способствует репаративным процессам в периапикальной области. Облепиховое масло, продукты пчеловодства, иммобилизированные формы фурацилина, мирамистина, 
стопангина с успехом применялись при лечении острых и обострившихся верхушечных периодонтитов.

К новым поколениям антисептиков относятся: мирамистин, триклозан, катапол, цидипол, кетамген АВ, листерин, велтолен, метацид и др.

Имеются сведения о применении различных методов физиотерапевтического воздействия при лечении верхушечных периодонтитов: высокоэффективно применение трансканального депофореза медного кальциумгидроксида, ультрафореза резорцин-формалиновой смеси. Но Совет Стоматологической ассоциации России не рекомендует применение резорцин-формалиновой смеси, так как формальдегид является токсичным ядом и оказывает канцерогенное и мутагенное воздействие.

Еще одним из способов, с помощью которого ученые пытались уменьшить количество микробов в инфицированном канале зуба, является использование обтурационных пломбировочных материалов с антимикробными и стимулирующими остеосинтез свойствами. Для этой цели широко использовался фосфат-цемент, но он не оказывает антимикробного и стимулирующего регенерационного действия и оказывает раздражающее действие на периодонт. Предпринимались попытки исследователями вводить различные добавки в виде антибиотиков, серебряных опилок, тимола, но они приводили к увеличению пористости материала и нарушению герметичности верхушечного отверстия.

Цинк-эвгеноловая паста и ее представители «Форфенан», «Foredent», «Биопласт» и др. вызывают острую воспалительную реакцию в периодонте с образованием микроабсцессов. Для полноценного контакта стенки корневого канала, с корневой пломбой использовалась разогретая гуттаперча, но цинкэвгеноловая паста лишь в ближайшие сроки после пломбирования обеспечивает отсутствие микробного проникновения в периодонт.

Широко использовалась резорцин-формалиновая паста, жидкость ее проникает в недоступные для инструментальной обработки участки каналов, поляризуясь под действием катализатора, замуровывает обрывки пульпы в 
канале. Паста обладает антисептическим, бактерицидным, противовоспалительным действием, но она оказывает раздражающее действие на периодонт, вызывая некроз тканей периодонта. Поэтому в 1997 году Стоматологической Ассоциацией России было принято решение не применять резорцин-формалиновый метод.

Эндодонтические пломбировочные материалы на основе смол (Ан-26, «Эндодент», «Ерохуса1» и др.) обладают высокой адгезией к стенкам канала, антисептическим действием, но они вызывают дистрофические изменения в дентине, очаговое замещение периодонтальных волокон грануляционной тканью.

В последнее десятилетие в стоматологии для пломбирования корневых каналов стали применять кальций содержащие материалы, которые способствуют регенерации костной ткани в периодонте. К представителям этого класса пломбировочных материалов относятся «Endocal» фирмы «Septodont», «Sealapex» фирмы «Kerr» и другие, содержащие гидроксид кальция. Обтурация каналов гидроокисью кальция не обеспечивает стерильности, хотя в ближайшие сроки приводит к некоторому подавлению микрофлоры.

Много работ в стоматологии посвящено использованию гидроксиапатита в сочетании с препаратами антимикробного действия для восстановления костной ткани в периодонте, за счет близости строения с живой тканью кости. Синтетический микродисперсный гидрооксиапатит «Остим-100» соответствует требованиям международного стандарта ASTM:F $1185-88$, позволяет уменьшить количество осложнений после пломбирования корневых каналов зубов. Однако исследования последних лет убедительно доказывают, что после традиционных методов лечения, более чем в $75 \%$ случаев в дентине зубов сохраняется инфекция. Низкая клиническая эффективность при эндодонтическом лечении традиционным методом отражены во многих работах. Приведенные данные подтверждают мнение, что традиционная эндодонтия сконцентрировалась на инструментальной 
обработке каналов, недооценивая значения полноценной дезинфекции каналов.

Вышеизложенное позволяет считать, что при лечении острых и обострившихся верхушечных периодонтитов необходимо использовать комплекс мероприятий, направленных на применение современных механических методов обработки корневых каналов, а также использование новейших антисептиков и доставки их при помощи физической энергии во все микроканалы с целью ликвидации патогенной микрофлоры, купирования воспалительного процесса и восстановления очагов деструкции в периодонтальной области.

\section{4. Современные методы лечения верхушечных периодонтитов}

Антисептик «Велтосепт», характеристика, применение. В последние два десятилетия в эндодонтии произошли изменения во всем, что касается как точки зрения на процессы, происходящие в корневых каналах, так и более эффективных способов эндодонтического лечения.

Успех эндодонтического лечения зависит от тщательности очистки корневого канала, что невозможно без инструментальной обработки, а инструментальная обработка невозможна без надежных инструментов. К настоящему времени создано большое разнообразие инструментов для внутриканальной обработки, причем каждый из них выполняет специфическую функцию.

Подробная характеристика инструментов не входит в наши планы, мы только остановимся на тех данных, которые были использованы в данной работе. Нами использовались для обработки корневых каналов эндодонтический наконечник X-Smart (Denstply), апекслокатор Raypex V (VDW), инструменты из никель-титанового сплава Profile (Denstply) и применялась методика прохождения корневых каналов Crown-Down.

Механическая обработка корневого канала значительно уменьшает количество бактерий, однако, оставшиеся в канале сохраняют жизненный 
потенциал, способность к размножению. Это обстоятельство указывает на необходимость дезинфекционной обработки корневого канала.

Современное развитие фармацевтической индустрии обеспечивает поступление в медицину новых дезинфицирующих препаратов.

Новые дезинфицирующие средства для применения в стоматологии должны отвечать следующим требованиям: иметь низкую токсичность, адекватную концентрацию, широкий спектр микробиологической активности, маловероятность развития устойчивых штаммов микроорганизмов, не обладать мутативными и канцерогенными свойствами. Этим требованиям отвечает уникальное, универсальное дезинфицирующее средство, не содержащее хлор, «Велтосепт», производство НПО «Велт» (Оренбург, Россия), свидетельство о государственной регистрации № 77.99.36.2.У.14304.12.06 от 26.12.2006г. Методические указания разработаны Научно-исследовательским институтом дезинфектологии Минздрава России.

«Велтосепт» представляет собой бесцветную жидкость, готовую к применению. В качестве действующего вещества содержит клатрат четвертичного амммониевого соединения с карбамидом $(0,1 \% \pm 0,01)$ и изопропиловый спирт $(70 \% \pm 3,0)$, выпускается в емкостях 0,$1 ; 0,25 ; 0,4 ; 0,5$ дм $^{3}$, со сроком годности 5 лет. Средство «Велтосепт» обладает антимикробной активностью в отношении грамположительных и грамотрицательных бактерий (включая возбудителей туберкулеза, внутрибольничных инфекций), дрожжеподобных грибов рода Кандида, вирусов (в том числе возбудителей гриппа, острых респираторных вирусных инфекций, парентеральных вирусных гепатитов, ВИЧ-инфекций, герпеса, ротавирусных гастроэнтеритов, энтеровирусных инфекций гепатита $\mathrm{A}, \mathrm{B}, \mathrm{C}$, полиомиелита), особо опасных инфекций (чума, холера, сибирская язва), возбудителей сальмонеллезов, брюшного тифа, дизентерии, дифтерии, скарлатины, венерических болезней. В режиме применения вызывает гибель 99,99\% микроорганизмов. 
Средство обладает пролонгированным антимикробным действием не менее 3 часов. По параметрам острой токсичности по ГОСТ 12.1.007-76 средство «Велтосепт» относится в 4-му классу малоопасных соединений при введении в желудок и нанесении на кожу. Препарат не обладает местнораздражающим, кожно-резорбтивным и сенсибилизирующим действием. По степени летучести средство малоопасно. Препарат предназначен для обработки операционного, инъекционного поля, обработки рук хирургов, акушерок, операционных медицинских сестер в лечебно-профилактических учреждениях хирургического, акушерского, стоматологического, педиатрического, кожно-венерологического профиля и др. Указанные свойства «Велтосепт», а также отсутствие данных о его использовании в стоматологической практике позволили нам оценить возможность его применения в качестве дезинфектанта при обработке корневых каналов зубов при лечении верхушечных периодонтитов. Качество продукции ЗАО «Велт» подтверждено Золотым знаком качества «Российская марка», «Всероссийская марка» - знак качества XXI века, почетным дипломом «Лучший отечественный товар», «Технологии России».

1.5. Применение ультразвука для санации системы макро- и микроканалов при лечении острых и обострившихся хронических верхушечных периодонтитов

Хорошо известно, что устранение патологических бактерий из системы корневых каналов в процессе эндодонтического лечения является сложной задачей. Результат микробиологических исследований свидетельствует о недостаточности только механического препарирования корневого канала. Эффективный доступ антисептика в систему может быть обеспечен лишь полноценным удалением «смазанного слоя», который представляет собой продукт механической обработки и состоит из обрывков тканей пульпы, фибрина и дентинных стружек. «Смазанный слой» запечатывает дентинные трубочки, создавая комфортные условия для жизнедеятельности микрофлоры. Резко снижается эффективность медикаментозной обработки. 
Даже пломбирование канала не решает проблему, а лишь усугубляет ее. Надежно изолированные со стороны корневого канала от доступа кислорода, анаэробы активно размножаются, продукты их жизнедеятельности проникают в периодонт и вызывают воспаление, сопровождающееся резорбцией костной ткани.

Исследования показали, что отсутствие микроорганизмов в корневом канале на момент обтурации повышает процент успеха на 94\% случаев, в то же время как присутствие их в канале процент успеха снижало до 68\% и адекватного заживления в периодонте добиться не удавалось.

Несмотря на значительное усовершенствование эндодонтического инструментария и методик, на сегодняшний день невозможно обеспечить полную дезинфекцию корневых каналов только механическим и медикаментозным путем.

Данные проблемы эндодонтического лечения стимулируют поиск путей наиболее рационального их решения. Сегодня в распоряжение стоматолога предоставлены уникальные технологии на основе ультразвуковой, лазерной, световой энергии, позволяющие эффективно с высокими показателями качества решать задачи в разных областях клинической стоматологии.

Применение ультразвука (УЗ) в медицине, в том числе в стоматологии, связано с особенностями его распространения и характерными свойствами. По физической природе УЗ, как и звук, является механическими колебаниями твердой, жидкой или газообразной среды, влекущими за собой возникновение в ней последовательно чередующихся участков сжатия и растяжения - волн. УЗ свойственны волновые колебания. Характеристики распространения: поглощение, интенсивность, давление, распространение, кавитация, тепловой эффект.

Основой биологического действия ультразвука (У3) является его способность поглощаться тканями живого организма. Энергия поглощенного УЗ трансформируется в другие виды энергии, вызывая ряд физических, физико-химических процессов и биологических реакций. Они приводят к 
изменению гомеостаза клеток тканей и организма в целом. Под действием УЗ в тканях попеременно происходят сжатие и растяжение частиц, что приводит их в колебательное движение. Механические колебания тканевых частиц приводят к «клеточному массажу», сдвигов химико-физических процессов и образованию тепла. При большой интенсивности УЗ в фазе растяжения может происходить разрыв межмолекулярных сил сцепления, притяжения и возникновения микрополостей - кавитация. Образующиеся при кавитации пузырьки в фазе сжатия мгновенно исчезают, а возникающие при этом ударные волны, электрические заряды и высокие локальные температуры инициируют специфические звуко-химические реакции в озвученной среде. В гетерогенной среде возникают мелко- и среднемасштабные течения и турбуляции, которые существенно ускоряют процессы растворения веществ.

В стоматологии впервые в середине 50-х годов прошлого века было предложено использовать УЗ для удаления зубных отложений. Наконечники для лечения зубов состоят из стержневого УЗ-пьезокерамического или аэродинамического преобразователя, где энергия электрических (электромеханических) колебаний трансформируется в энергию механических колебаний в диапазоне 20-45 кГц.

Не вызывает сомнений применение уникального, в смысле многокомпонентности, воздействия на внутреннюю среду системы корневых каналов зубов ультразвукового стоматологического аппарата «Amdent US 30 D», разработанного шведской фирмой «Amdent».

Аппарат «Amdent US 30 D» имеет три быстросъемных наконечника для эндодонтии: эндо W 70/70, эндо W 90/90, эндо W 110/110. «Amdent US 30 D» дает возможность передавать физическую энергию в виде контролируемых ультразвуковых колебаний через файл к стенкам канала. Кавитация и акустический поток оказывают повреждающее действие на клеточные оболочки бактерий и запускают асептические реакции в виде ирриганта, что дополнительно способствует дезинфекции системы канальцев и растворению органических соединений. Активный кислород, образующийся в процессе 
ультразвуковой обработки, является антагонистом анаэробов, подавляющим процесс гликолиза в метаболической цепочке бактериальной клетки и тормозящим рост клеточной популяции этих микроорганизмов.

Кроме того, обработанная ультразвуком поверхность корневого канала является идеальной в отношении адгезии пломбировочного материала, что играет важную роль в профилактике вторичного внедрения микрофлоры в периапикальные ткани, снижая риск возникновения осложнений в отдаленные сроки после данного лечения.

Исследования показали, что для удаления остатков тканей, предентина и дентина ультразвуковые алмазные файлы более эффективны, чем К- и Нфайлы. Ультразвук активирует режущую способность файлов за счет пространственного сглаживания стенок канала, делая поверхность стенок корневого канала очень гладкой, чего очень трудно достичь при эндодонтических манипуляциях.

Применение ультразвука повышает эффективность антисептической обработки системы макро- и микроканалов корней. Количество бактерий в системе корневых каналов после такой обработки было ниже, чем после ручной обработки и группе контроля. Ультразвуковые колебания, создавая эффект кавитации, разрушают бактерии, механически очищают дентинные трубочки с наибольшей эффективностью.

В целом действие на биологический объект происходит через акустическую среду (растворы антисептиков, антибиотиков, ферментов). Для эндодонтической обработки каналов, для ирригации совместно с УЗ используют раствор гипохлорита натрия.

Для эффективного эндодонтического лечения необходимо обеспечить стерильность макро- и микроканалов, обтурацию их, а также стимуляцию репаративных процессов в периапикальной области. На основании теоретических и экспериментальных исследований единственным перспективным подходом в эндодонтии является обработка канальной системы препаратом, способным перемещаться под действием кавитации 
ультразвука. В этом случае не играют никакой роли ни форма канала, ни его диаметр, ни длина. Наличие возможности использования ультразвука системы «Amdent US 30 D» с лечебным раствором обеспечивает комплексное физико-химическое воздействие во время эндодонтической обработки, так как УЗ возбуждает циркуляцию антисептика в одном направлении в микроканальцы, озвученный дезинфектант способствует раскрытию облитерирующих канальцев, воздействует на микрофлору макро- и микроканалов бактерицидно, бактериостатически и цитотоксически, обеспечивая бесконтрольную очистку корневой системы, в том числе в труднодоступных местах.

Медикаментозная обработка корневых каналов должна проводиться антисептиком, обладающим бактерицидным, безвредным быстродействующим, не сенсибилизирующим, глубоко проникающим, длительно эффективным, химически стойким действием. Антисептик «Велтосепт» и ультразвук аппарата «Amdent US 30 D», при лечении верхушечных периодонтитов проводится с целью полноценной санации корневых каналов зубов.

\section{6. Биостимулирующий свет «Bioptron» в комплексном лечении острых и обострившихся хронических верхушечных периодонтитов}

Светотерапия используется в медицине уже давно. Первоначально источником исцеления служил обычный солнечный свет. Даже древние египтяне уже знали о целительной силе солнечных лучей, в трудах Гиппократа встречается описание целебного воздействия солнечного света на организм. Отцом современной светотерапии считают датского ученогомедика Н.Р.Финсена, который в 1903 году получил Нобелевскую премию за свои исследования в области светотерапии и за создание первого в мире прибора, способного генерировать свет. В 1981 году группой венгерских исследователей на базе лазерных установок был создан источник света, спектром которого являлась комбинация из видимого света и инфракрасного 
излучения, полностью исключая ультрафиолетовые волны, была создана система светотерапии «Bioptron».

При характеристике света «Bioptron» необходимо отметить, что биологический эффект светотерапии «Bioptron» определяется, главным образом, такими факторами, как:

- поляризация - свет, излучаемый прибором «Bioptron» - поляризован это значит, что его световые волны распространяются в параллельных плоскостях. Степень поляризации света «Bioptron» достигает 95\%;

- полихроматичность - свет, излучаемый прибором «Bioptron» полихроматичен. В отличие от лазерного света, содержащего всего лишь одну длину волны, он обладает широким спектральным свойством, включая видимый свет, и, частично, инфракрасное излучение. Длина волны, излучаемая прибором - от 480 нм до 3400 нм, проникает на глубину 2,5-3 см. Электромагнитный спектр «Bioptron» полностью исключает ультрафиолетовые волны;

- некогерентность (отсутствие фазы) - в отличие от лазерного излучения, свет «Bioptron» не имеет фазы, это означает, что волновое движение не синхронизировано;

- низкоэнергетический свет - свет лампы «Bioptron» имеет низкую плотность энергии светового потока. Эта невысокая постоянная плотность обладает ярко выраженным биостимулирующим свойством, положительно влияющим на различные биологические процессы в организме;

- биостимуляция - свет «Bioptron» оказывает биостимулирующий эффект: при воздействии на кожу происходит стимуляция светочувствительных клеточных структур. С этого начинается цепь клеточных реакция и запуск так называемых «вторичных ответов», которые не ограничиваются только областью воздействия света на кожу, а распространяются на весь организм. Светотерапия «Bioptron» стимулирует и нормализует регенеративные процессы организма, а также его защитные 
силы. Светотерапия «Bioptron» способствует естественной регенерации организма, укрепляет иммунную систему и улучшает здоровье.

Низкоэнергетический свет «Bioptron» с видимым и частично инфракрасным широким спектральным составом без ультрафиолетовой волны, обладает мощным биостимулирующим действием, в основе которого лежит структурно-функциональная перестройка мембранных образований клетки, которая, поглощая энергию лампы «Bioptron», формирует ответную реакцию на световое возбуждение, усиливая биоэнергетические и биосинтетические процессы. По данным экспериментальных исследований, механизм действия света связан со структурно-функциональными изменениями компонентов циркулирующей крови:

- нормализуется деформированность и вязкость эритроцитов,

- улучшаются реологические свойства крови, ее микроциркуляция, газообмен, транспортная функция,

- повышается функциональная активность лейкоцитов.

Один из механизмов стимуляции поляризованным светом митотической активности клеток связан с более активной элиминацией клеток $\mathrm{c}$ поврежденной ДНК, нормализуется структура клеточной мембраны за счет стабилизации липопротеинового слоя, усиливается выведение свободных радикалов, стимулируется синтез АТФ, улучшая процессы окислительного фосфолирования и перекисного окисления липидов. Изменение реологических показателей крови через лимбическую систему и гипоталамус увеличивает количество нейромедиаторов - адреналина и норадреналина, путем активации ферментов тирозингидроксилазы и трансферазы. После светотерапии поляризованным светом, увеличивались факторы гуморального иммунитета - иммуноглобулинов.

Цитологические исследования показали, что свет «Bioptron»:

- стимулирует функцию митохондрий,

- ускоряет пролиферацию клеток, 
- повышает функцию рибосом, которые обеспечивают повышение уровня защитных ферментов лизоцима крови и слюны, интерферона и комплемента.

Одновременно происходит ингибирование процессов альтерации, экссудации, пролиферации и в результате - снижение отека, улучшение микроциркуляции, ускорение регенерации ткани. На системном уровне свет «Bioptron» оказывает воздействие на нейро-эндокринную и иммунную системы, кроветворение, кровообращение, трофику и регенерацию.

Биопозитивные эффекты света «Bioptron»:

1) противовоспалительный эффект,

2) ускорение заживления ран,

3) стимуляция иммунной системы и обменных процессов,

4) обезболивающий эффект.

Противовоспалительное действие. При терапевтическом действии системы света «Bioptron» происходит одновременная активация процессов альтерации, экссудации, пролиферации. Воздействуя светом лампы «Bioptron» через слизистую оболочку на воспалительный процесс причинного зуба, происходит оптимальное формирование фагоцитарной активности микро- и макрофагов, стимуляторов роста и пролиферации, активация барьерных свойств слизистой оболочки, что выражается в нормализации микроциркуляции кровообращения и проницаемости сосудистой стенки, уменьшением отека тканей. Альтерация сопровождается активацией клеточных органелл и мембран, метаболизма с увеличением потребления кислорода и активацией тканевого дыхания. В результате подавления анаэробных процессов, предотвращения ацидоза, ускоряется регенерация поврежденных тканей. При пролиферации стимулируются системы ДНК-РНК-белок, наблюдается увеличение активности клеток, активация реакций соединительной ткани, стимуляция образования грануляционной ткани, ускорение созревания фибробластов и коллагеновых волокон, повышение функции рибосом и объема белковой массы, 
необходимой для ускорения размножения клеток, вследствие чего происходит быстрая и полноценная регенерация.

Ускорение заживления ран - регенерационное действие. Светотерапия «Bioptron» оказывает положительный эффект на поврежденную ткань и ускоряет заживление. Благодаря улучшению микроциркуляции, активации синтеза коллагена и клеток кожи, необходимых для процесса заживления, ускоряет процесс эпителизации.

Клетки тканей под воздействием света «Вioptron» увеличивают субстанции роста, активируют систему ДНК-РНК-белок, усиливая синтез нуклеиновых кислот и ядерных белков, стимулируя митоз, ускоряя размножение клеток соединительной ткани, эпителия. Происходит образование и созревание грануляционной ткани, коллагенообразование и заживление раны первичным натяжением, приближая заживление к условиям естественной репаративной регенерации.

Стимуляция иммунной системы и обменных процессов. Под воздействием поляризованного, полихроматичного, некогерентного света «Bioptron» на патологический очаг в иммунокомпетентных системах происходит перераспределение клеток с увеличением количества эозинофилов, базофилов и лимфоцитов, миграция лимфоцитов в кровеносном русле и ускорение выхода сегментоядерных нейтрофилов в очагах воспаления. Повышается уровень неспецифических гуморальных факторов - интерферона, комплемента, лизоцима; увеличивается образование специфических стимуляторов роста - лейкоэпинов, стимулирующих костномозговое образование. Активизируются функции систем Т- и В-лимфоцитов, их пролиферативная активность, вследствие чего происходит активация систем гуморальной и клеточной специфической защиты организма.

Низкоэнергетический поляризованный свет «Bioptron» обладает также общим воздействием на организм, в частности на системы - иммунную, нейрогуморальную, кроветворную. Интенсивность его воздействия зависит 
от площади и объема облученной ткани: чем больше эти величины и общая экспозиция облучения, тем выше воздействие излучаемого света на организм.

Обезболивающий эффект. Установлено, что анальгезирующий эффект под воздействием света «Bioptron» возникает в результате стимулирующего действия на нейроны, улучшая проводимость импульсов по нервным волокнам, снижая биологическую активность рецепторов кожи, вызывая блокаду болевого очага, стимулируя регенерацию нервных волокон после их повреждения. Обезболивающий эффект поляризованного света от лампы «Bioptron» проявляется во время процедуры и длится до нескольких часов. Низкоэнергетический свет при воздействии на ткани малыми дозами оказывает нейротропное воздействие на нервные клетки, вызывая ускоренное проведение импульсов по нервным волокнам и стволам, активизируя функции нервных ганглиев, синопсов, секреторную функцию адреналина и ацетилхолина, обуславливая анальгезирующее действие.

Побочные негативные эффекты воздействия системы светотерапии «Bioptron» неизвестны.

Система светотерапии «Bioptron» широко используется во всем мире, как новый немедикаментозный метод лечения в клинической практике.

\subsection{1. Результаты использования системы света «Bioptron» в клинической практике российский врачей.}

Определение эффективности поляризованного, полихроматического, низкочастотного света лампы «Bioptron» изучалось в различных медицинских учреждениях Российской Федерации. При поражении опорнодвигательной системы и ревматических заболеваний суставов результаты лечения свидетельствуют о выраженном противовоспалительном, противоотечном, анальгезирующем действии поляризованного, полихроматического света лампы «Bioptron».

Результаты бионикотерапии в хирургической практике (медицинская академия им. И.М.Сеченова) свидетельствуют об ускоренном заживании ран 
после воздействия низкочастного света лампы «Bioptron», отсутствие гнойных осложнений, сокращение сроков пребывания больного в клинике. О явно лечебном действии и необходимости применения в сочетании с другими видами лечения низкочастотного поляризованного света «Bioptron» свидетельствуют исследования областного отделения пластической хирургии и эстетической микрохирургии г.Челябинска.

Данный метод раскрывает новые терапевтические возможности в акушерстве, в комплексном лечении раневых послеродовых инфекций, гинекологии (осложнения снизились до 21\%), что свидетельствует о высоких репаративных и иммунологических свойствах поляризованного света лампы «Bioptron». При лечении и профилактике урологических заболеваний установлено, что светотерапия низкочастотного поляризованного, полихроматичного света ускоряет процесс заживления пораженных тканей и органов. Эффект лечения лампой «Bioptron» столь же гениален, как и прост «чудо XXI века, лечит без лекарств». Следует отметить эффективность бионикотерапии в процессе комплексной терапии дерматозов, сопровождающихся воспалительными явлениями образования трещин, эрозий, язв. Испытание бионики в ожоговом центре г.Москвы в ходе клинических наблюдений, показало эффективность лампы «Bioptron» при лечении ожогов I, II, III степени в пред- и послеоперационных периодах течения раневого процесса. Под влиянием проводимого лечения медленно происходило отторжение некротических тканей, периферическое воспаление быстро купировалось, что способствовало сохранению фалангов травмированных органов. Положительный результат был достигнут при лечении аллергических заболеваний: острых и хронических ринитов, конъюнктивитов, аллергических дерматозов. Положительный эффект поляризованного света достигается за счет повышения иммунитета, стимуляции метаболизма, улучшения циркуляции крови, в результате чего уменьшается интенсивность воспалительного болевого синдрома. Клиническая апробация линейно-поляризованного света в практике лечения 
стоматологических заболеваний показала, что этот свет обладает противовоспалительным действием (заживление происходит на 20-25\% быстрее), не вызывает никаких осложнений, аллергических реакций. Основные показания к применению лампы «Bioptron»: гингивиты, стоматиты, абсцессы, флегмонты, пародонтиты, глосситы, глоссалгии, раны, ссадины.

Настоящее исследование проводится с целью исследования эффективности использования поляризованного, полихроматичного света «Bioptron» при лечении острых и обострившихся верхушечных периодонтитов в сочетании с озвученным раствором «Велтосепт» для полноценной санации системы макро- и микроканалов. Это обеспечит возможность проведения высокоэффективной, патогенетической, многофакторной терапии верхушечных периодонтитов.

\section{7. Современные материалы для пломбирования корневых каналов зубов при верхушечных периодонтитах, применяемые в работе}

Успех пломбирования корневых каналов в значительной степени определяется качеством предыдущих эндодонтических манипуляций (обеспечение доступа к устью канала, его расширения, выравнивания стенок, создания упора) и, в основном, обуславливает исход проводимого лечения. Основным требованием данного этапа лечения является надежность герметизации корневого канала, исключающая возможность его сообщения с периодонтом и полостью зуба. Пломбировочные материалы должны отвечать следующим требованиям: отсутствие раздражающего действия на периодонт; оказание антисептического и противовоспалительного действия; способствовать костеобразованию; легко вводиться; медленно затвердевать; быть рентгеноконтрастным; при необходимости извлекаться из корневого канала. К сожалению, до сих пор не создан материал для обтурации корневых каналов, который бы отвечал всем требованиям. В настоящее время используются пломбировочные материалы: AH Plus, AH-26 (фирмы Dentsply); Реодент, Крезодент (ООО ВладМиВа); Endomethasone, Endobtur, 
Forfenan (фирмы Septodont); Биодент (НПО Медполимер); Эвгедент (ООО «Радуга России); Sealapex (фирмы Kerr) и др. Для устранения воспалительного процесса и стимуляции репаративного остеогенеза в периапикальной области при лечении верхушечных периодонтитов в стоматологии широко используют гидроксиапатит. Структурными компонентами гидроксиапатита являются кальций и фосфат, его химическая формула $\mathrm{Ca}_{10}\left(\mathrm{PO}_{4}\right)_{6}(\mathrm{OH})_{2}$. Препарат обладает остеотропным действием, нетоксичен, имеет идеальную совместимость. Широко используется в челюстно-лицевой хирургии при лечении заболеваний пародонта.

Синтетический мелкодисперсный отечественный гидроксиапатит марки «Остим-100» содержит малые размеры зерен 0,05 микрона и большую площадь их удельной поверхности 100-150 м/г, максимально близок к гидроксиапатиту живой костной ткани. Данный препарат соответствует требованиям международного стандарта ASTM: F 1185-88, имеет высокую величину удельной поверхности отдельных частиц, за счет этого обладает способностью стимулировать функциональную и пролиферативную активность остеобластов, являясь стимулятором репаративного остеогенеза. При лечении хронических верхушечных периодонтитов «Остим-100» позволяет уменьшить количество осложнений, наблюдающихся после пломбирования корневых каналов зубов и стимулировать репаративный остеосинтез в области околоверхушечного патологического очага. Данный препарат используют при лечении больных с патологией пародонта, это способствует уменьшению глубины пародонтальных карманов. После операции удаления зуба имплантация «Остим-100» поддерживает высоту альвеолярного отростка.

Эндодонтические пасты, содержащие гидроксиапатит проявляют при их введении в периапикальные ткани высокую биологическую совместимость, способствующую уменьшению числа и выраженности ранних осложнений, а также повышают резистентность твердых тканей зуба. 
Нанотехнологии последних лет позволили создать новейшие разработки остеопластических материалов на основе аморфного нанодисперстного резорбируемого гидроксиапатита кальция «Остеоиндуцин» и «Гиалуост» (НКФ «Омега-Дент») для восстановления и заполнения дефектов костной ткани.

В качестве постоянного пломбировочного материала в работе применялся отечественный гидроксиапатит «Остеоиндуцин» фирмы «ОмегаДент», остеопластический материал на основе аморфного нанодисперсного резорбируемого гидроксиапатита кальция для восстановления и заполнения дефектов ткани и повышения резистентности твердых тканей депульпированных зубов. Новизна материала «Остеоиндуцин» заключается в технологии синтеза биоактивного, аморфного, нанодисперсного гидроксиапатита кальция, единственным продуктом которого является микрогранулят с диаметром гранул - 0,5-1мкм и волокон, неплотно сформированных из этих же частиц, включенных в полисахаридную матрицу. Одним из основных отличий технологии получения биоактивного, аморфного нанодисперсного гидроксиапатита кальция, входящего в состав материала «Остеоиндуцин», является отсутствие побочных продуктов, и как следствие, возможность включения в процесс синтеза, что позволяет получить высокочистый биоактивный материал $\mathrm{c}$ повышенной биосовместимостью, оказывающий стимулирующее действие на рост клеток. Введенный в место контакта «Остеоиндуцин», активирует остеогенез, усиливает пролиферативную активность остеобластов и стимулирует процессы репаративного остеогенеза на месте введения, а так же задерживает воспалительные процессы в костной ткани. Характеризуется биосовместимостью с организмом человека и не вызывает реакции отторжения. Рекомендуется для применения в стоматологии:

- пародонтология: заполнение двух- или многостеночных костных карманов, а также би- и трифуркационных зубов, аугментация атрофированной челюстной пазухи; 
- имплантология: синуслифтинг или поднятие синусового основания (субантральная аугментация), заполнение альвеолярных дефектов для поддержания челюстной пазухи после экстракции зуба, заполнение экстракционных дефектов с целью создания основы для имплантата;

- кистовые дефекты: дефекты после экстирпации костной кисты;

- дефекты после резекции верхушки корня;

- дефекты после удаления ретенированных зубов хирургическим путем;

- прочие многосеточные костные дефекты альвеолярных отростков лицевого черепа.

Известно, что даже при хорошо проведенном заполнении корневого канала корня зуба ликвидация очага хронического воспаления в периодонте длится не один месяц и зависит от вирулентности бактерий и состояния иммунитета больного. Ассоциативная флора продуцирует ферменты и эндотоксины, которые препятствуют процессам хемотаксиса, фагоцитоза в периодонте и ингибируют активность антибактериальных препаратов. Поэтому наряду с общепринятыми технологиями обработки корневых каналов и их обтурации проводят временную корневую обтурацию с целью пролонгированного антисептического действия на систему корневых каналов деструктивных форм хронических верхушечных периодонтитов. Исследования различных авторов показали, что после временного запечатывания корневых каналов различными составами гидроксида кальция, бактерии в 97\% случаев не выживают. Гидроксид кальция $\mathrm{Ca}(\mathrm{OH})_{2}$ слаборастворим в воде, $\mathrm{pH}-12,4$, сохраняется в перенасыщенном водном растворе (дистиллированной воде) в герметичном сосуде. Высокий $\mathrm{pH}$ гидроксида кальция (щелочность) обуславливает воздействие на микроорганизмы и разрушение некротизированных тканей. Обычно бактерии погибают при рН-9,5 и только некоторые - свыше 11. При введении в корневой канал гидроксида кальция $\mathrm{pH}$ в дентине достигает 10. Важным остается вопрос о сроке сохранения активности гидроксида кальция. Установлено, что $\mathrm{Ca}(\mathrm{OH})_{2}$, поглощая $\mathrm{CO}_{2}$ из воздуха, способен превращаться 
в $\mathrm{CaCO}_{3}$, однако, при хорошей герметичности в закрытых емкостях это происходит очень медленно, поэтому при правильном использовании порошок $\mathrm{Ca}(\mathrm{OH})_{2}$ или пасты имеют длительный срок годности. Гидрооксид кальция получил всеобщее признание клиницистов в качестве временного заполнителя корневых каналов, особенно как антибактериальный агент, методом выбора является паста гидроксида кальция. На рынке стоматологической продукции имеется большой выбор препаратов, содержащих гидроксид кальция. Это Life (Kerr), Calcimol (Voco), Dycal (Dentsply), Hypocal, Endocal (Spad), Acroseal (Septodont), Апексдент (ООО ВладМиВа), РИОДЕНТ-С (ООО «Радуга»), «Кальсепт» и другие. В нашей работе для временного заполнения корневых каналов применен материал «Кальсепт» (НКФ «Омега-Дент») на основе гидроокиси кальция в виде пасты без йодоформа. Стоматологический материал «Кальсепт» выпускается в виде готовой к применению рентгенконтрастной пасты, содержащей гидроксид кальция, и индуцирующей образование костной ткани, благодаря высокому уровню РН (выше 12) оказывающее асептическое пролонгированное действие в корневых каналах.

«Кальсепт» имеет высокое значение $\mathrm{pH}$ (11-12). Состав: кальция гидроксид, сульфат бария, стерильный изотонический раствор. Материал (паста) расфасован в 2 пластиковых шприца (стерильно) с 20 специально стерильными канюлями. Препарат оказывает антисептическое пролонгированное действие на систему корневых каналов. Материал вводится в корневой канал и, действуя в дентине как антисептик, стерилизует его, приводя механизмы интеграции цементобластов, стимулируя биологический барьер в околоверхушечной области зуба.

Настоящее исследование проводилось с целью изучения эффективности использования новейшего антисептика «Велтосепт» в озвученной среде в комплексе с воздействием света «Bioptron» и пломбированием корневых каналов нанодисперсными материалами, что позволит наиболее рационально воздействовать на все патологические звенья при лечении ОВП и ОХВП и 
обеспечить возможность проведения высокоэффективной, патогенетической, многофакторной терапии.

\section{ГЛАВА 2. МАТЕРИАЛ И МЕТОДЫ ИССЛЕДОВАНИЯ}

Работа выполнялась в два этапа:

- экспериментальный (микробиологическое исследование);

- клинический (клинико-рентгенологическое и иммунологические исследования). Оценка эффективности применения светотерапии лампы «Bioptron» проводилась в комплексном лечении острых явлений в периодонте с предварительной медикаментозной обработкой корневых каналов антисептиком «Велтосепт» с ультразвуком внутриканально.

\section{1. Материалы и методы микробиологического исследования}

2.1.1. Изучение микрофлоры корневых каналов зубов у больных с острыми явлениями в периодонте

Для выполнения поставленных задач изучено влияние биостимулирующего света в сочетании с медикаментозной обработкой системы каналов «Велтосептом» в озвученной среде и без него на штаммы различных микроорганизмов.

Материал из корневых каналов забирали стерильными турундами, которые помещали в пробирки с раствором натрия хлорида $(1,5$ мл $0,9 \%)$ и хранили в условиях холодильника при $\mathrm{t}+4^{0} \mathrm{C}$ до начала исследования. Исследовали как нативные образцы, так и пробы с разведением десятикратно $\left(10^{-1} ; 10^{-2}\right)$, все пробы изучали одновременно.

В качестве питательных сред использовали сывороточно-декстрозный, триптозный и кровяной агары (pH 7,4), которые после расплавления остужали до $56^{\circ} \mathrm{C}$ и по 25 мл разливали в чашки Петри, предварительно поместив на дно чашки 1,0 мл исследуемой взвеси содержимого корневого канала в соответствующем разведении. Чашки оставляли при комнатной температуре до застывания агара, затем помещали их в термостат и инкубировали при температуре $37^{0} \mathrm{C}$ в течение 14 суток. Ежедневно 
проводили учет колоний выросших как в толще агара, так и на его поверхности. Культуры, выросшие в толще агара, рассматривались как анаэробы, на поверхности агаровой пластинки - как аэробы.

\subsection{2. Определение штаммов микроорганизмов, используемых в эксперименте}

Первоначально нами были изучены представители микрофлоры корневых каналов зубов больных с острыми явлениями в периодонте. Выделены представители смешанной флоры с доминантой грамотрицательных анаэробных микроорганизмов.

В эксперименте были использованы 50 штаммов микроорганизмов, из них: Staphylococcus aureus - 20, Streptococcus - 20, E.coli-10. Размножение культур определяли в условиях термостата при $\mathrm{t}-37^{0} \mathrm{C}$ в течение 24-48 часов на плотных питательных средах.

\subsection{3. Определение минимальной подавляющей концентрации велтосепта на плотной питательной среде}

Чувствительность микроорганизмов к велтосепту изучали методом серийных разведений препарата на плотной питательной среде.

В качестве плотной питательной среды применяли триптозный агар (рH7,4). Готовили разведение препарата в стерильной водопроводной воде, для чего основной патентованный раствор велтосепта приняли за 100\% и разводили последовательно двукратно, получая растворы следующих концентраций $(100 ; 50 ; 25 ; 12,5 ; 6,25 ; 3,125 ; 1,562 ; 0,781 ; 0,390 \% \%)$. В мерный объем (25 мл питательного агара, охлажденного до $56^{0} \mathrm{C}$, вносили по 0,25 мл определенного раствора велтосепта, получая в агаре следующие концентрации препарата: $(2,1 ; 1,05 ; 0,525 ; 0,263 ; 0,132 ; 0,066 ; 0,033 ; 0,016$; $0,008 \% \%)$.

По оптическому стандарту - образцу (OCO) мутность ГИСК им. Л.А.Тарасевича 10 единиц готовили взвеси культур в 0,9\% растворе натрия хлорида до конечной концентрации $1 \times 10^{9} ; 1 \times 10^{7} ; 1 \times 10^{5}$ микробных клеток в мл. Штамм-репликатором одновременно засевали 50 образцов взвесей 
культур на чашки с соответствующими разведениями велтосепта, инкубируя в термостате при $\mathrm{t}-37^{0} \mathrm{C}$ в течение 14 суток посевы. Ежедневно производили учет результатов. Оценку результатов производили по наличию или отсутствию роста культур в месте поселения на агар с соответствующей концентрацией велтосепта.

При отсутствии роста культур тест-штаммов в течение указанного срока антимикробное действие велтосепта оценивалось как бактерицидное, в противном случае - как бактериостатическое.

Минимальная подавляющая концентрация (МПК) велтосепта соответствовала наибольшему разведению препарата, обеспечивающему подавление роста культур изучаемых штаммов.

\subsection{4. Определение минимальной подавляющей концентрации велтосепта суспензионным методом}

Вначале готовили двукратное разведения велтосепта $(0,2 ; 0,1 ; 0,05$; $0,025 \% \%$ в стерильной водопроводной воде.

В полученные растворы вносили по 0,1 мл суспензий двухсуточных агаровых культур тест-таммов в 0,9\% растворе натрия хлорида. Контролем служили пробирки со стерильной водопроводной водой, куда также вносили тест-штаммы в той же дозе. Спустя 60 секунд из контрольных и опытных суспензий делали посевы на агаровые пластинки при комнатной температуре, которые инкубировали в термостате при $\mathrm{t}-37^{0} \mathrm{C}$ в течение 14 суток, проведя ежедневный учет результатов посевов. При отсутствии роста культуры в пробирках с раствором велтосепта, из них производили посев на плотные питательные среды для контроля эффективности действия препарата (бактерицидное, бактериостатическое).

Концентрация велтосепта в пробирке, в которой отсутствовал рост тестштаммов, считалась минимальная подавляющая концентрация (МПК) для данного вида микроорганизмов. 
2.1.5. Определение эффективности сочетанного действия раствора велтосепта и ультразвука на микрофлору корневых каналов зубов у больных с верхушечным периодонтитом

После инструментальной обработки корневого канала вводили ирригант - велтосепт и через 30 секунд обрабатывали канал ультразвуком с помощью файла при помощи эндодонтического наконечника эндо W 70/70 ультразвукового аппарата «Amdent US 30 D», после чего забирали материал для бактериологического исследования стерильной ватной турундой, помещая ее в 1 мл 0,9\% раствора натрия хлорида. Образцы выдерживали в холодильнике при температуре $+4^{0} \mathrm{C}$, после чего одновременно производили высев из всех проб клинического материала на агаровые пластинки по описанной ранее методике, а также в 4 мл триптозного бульона. Посевы инкубировали в течение 14 суток при температуре $37^{0} \mathrm{C}$, производя ежедневный учет результатов. При отсутствии роста на бульоне через указанный промежуток времени делали высев на плотную питательную среду. Эффективность антимикробного действия оценивали качественно по наличию или отсутствию роста колоний микроорганизмов на плотной питательной среде.

2.1.6. Определение эффективности биостимулирующего света лампы «Bioptron» в сочетании с озвученным раствором велтосепта на микрофлору корневых каналов зубов у больных с острыми явлениями в периодонтите

После инструментальной обработки корневого канала зуба и прекращения оттока экссудата воздействовали на область верхушки причинного зуба поляризованным светом лампы «Bioptron», после чего в канал вводили ирригант - велтосепт на 30 секунд и канал обрабатывали ультразвуком аппарата «Amdent US 30 D» при помощи наконечника W 70/70 с соответствующем файлом. Материал из канала забирался стерильной ватной турундой, которая помещалась в пробирку в 1 мл 0,9\% раствора натрия хлорида. По описанной методике определялась эффективность 
антимикробного воздействия по наличию или отсутствию микроорганизмов на плотной питательной среде.

\section{2. Клинические методы исследования}

2.2.1. Характеристика клинического материала и методик лечения острых и обострившихся хронических верхушечных периодонтитов различными лечебными комплексами с применением полихроматичного света «Bioptron» и без него

Клинические исследования проводились на базе кафедры пропедевтики стоматологических заболеваний Ставропольской государственной медицинской академии с информированного согласия пациентов.

Объектами клинических наблюдений послужили 200 пациентов (116 женщин и 84 мужчин) в возрасте от 18 до 40 лет, обратившихся по поводу лечения острых и обострившихся хронических форм верхушечного периодонтита.

При обследовании пациентов применялись основные (опрос и осмотр) и дополнительные (перкуссия, пальпация, электроодонтометрия, определение степени проходимости корневых каналов апекслокатором, рентгенография) методы обследования. При постановке диагноза применялась классификация верхушечных периодонтитов МГМСУ (2003).

Данные результатов обследования вносились в специально разработанную на кафедре карту. Карта включала: паспортные данные; анамнез заболевания; зубную формулу; данные микробиологического исследования; способ медикаментозной обработки системы каналов; методы физического воздействия - ультразвук, свет «Bioptron»; а также, материалы и способы пломбирования корневых каналов и кариозных полостей; данные рентгенографии, которая выполнялась до, после, через 3, 6 и 12 месяцев после лечения; сроки репаративного процесса в периодонте. Для сравнения динамики репаративных процессов в периодонте применялся периодонтальный индекс PAI. 
Оценку клинико-рентгенологических результатов лечения деструктивных периодонтитов в отдаленные сроки наблюдений проводили с применением периапикального индекса PAI в баллах.

При трактовке значений индекса состояние соответствующее:

- 1 баллу - оценивали как нормальный верхушечный периодонт;

- 2 баллам - костные структурные изменения, указывающие на апикальный периодонтит, но не типичный для него (острые экссудативные формы);

- 3 баллам - костные структурные изменения с некоторой потерей минеральной части (хронические фиброзные формы);

- 4 баллам - хорошо видимые структурные изменения с неровными контурами (хронические гранулирующие формы);

- 5 баллам - выраженное наличие гистологических признаков костных структурных изменений (хронические гранулематозные формы).

Препарирование твердых тканей зубов проводилось турбинным наконечником с алмазными борами. Для механической обработки корневых каналов применялись эндодонтические наборы инструментария и эндодонтические наконечники, а также апекслокатор Raypex V (фирмы VDW) для определения степени проходимости корневых каналов. Купирование острых симптомов воспаления осуществлялось светотерапией лампы «Bioptron». Медикаментозная обработка системы макро- и микроканалов осуществлялась различными дезинфектантами, в том числе новейшим антисептиком «Велтосепт» с применением ультразвука и без него.

Для пломбирования корневых каналов зубов изучались различные пломбировочные материалы как традиционные, так и предложенные нами с включением в их состав гидроксиапатита «Остеоиндуцин», а также материал, содержащий гидроксид кальция «Кальсепт» для отсроченного метода лечения. Восстановление анатомической формы зубов проводилось светоотверждающим композиционным пломбировочным материалом «Estelite» с прокладкой из стеклоиономерного цемента «Ionosit». 
У каждого больного было вылечено по одному зубу с воспалением верхушечного периодонта. Продолжительность курса лечения определялась для каждого больного индивидуально. Общая характеристика клинических групп представлена в таблице 1.

Таблица 1

Распределение больных в зависимости от формы верхушечного периодонтита

\begin{tabular}{|l|l|l|l|l|}
\hline \multirow{2}{*}{$\begin{array}{l}\text { Груп- } \\
\text { па }\end{array}$} & Подгруппы & Форма верхушечного периодонтита & \multicolumn{2}{|c|}{$\begin{array}{l}\text { Количество } \\
\text { больных }\end{array}$} \\
\cline { 4 - 6 } & & абс. & $\%$ \\
\hline I & $1,2,3,4,5$ & Острый в фазе интоксикации - ОВПСИ & 50 & 25,00 \\
\hline II & $6,7,8,9,10$ & Острый в фазе экссудации - ОВПСЭ & 50 & 25,00 \\
\hline III & $11,12,13,14,15$ & $\begin{array}{l}\text { Обострившийся хронический гранулирующий - } \\
\text { ОХВГрП }\end{array}$ & 50 & 25,00 \\
\hline IV & $16,17,18,19,20$ & $\begin{array}{l}\text { Обострившийся хронический гранулематозный - } \\
\text { ОХВГП }\end{array}$ & 50 & 25,00 \\
\hline \multicolumn{2}{|c|}{ Итого } & 200 & \\
\hline
\end{tabular}

Из таблицы 1 следует, что четыре группы больных включали по 50 человек с различными формами верхушечных периодонтитов. Каждая из групп была разделена на 5 подгрупп (по 10 человек) в зависимости от комплекса лечебных воздействий.

Анатомическая принадлежность исследованных и вылеченных зубов различными лечебными комплексами представлена в таблице 2.

Таблица 2

Распределение вылеченных зубов по анатомической принадлежности

\begin{tabular}{|l|c|c|c|c|}
\hline \multirow{2}{*}{$\begin{array}{c}\text { Групповая } \\
\text { принадлежность } \\
\text { зубов }\end{array}$} & \multicolumn{2}{|c|}{ Челюсти } & \multicolumn{2}{c|}{ Количество зубов } \\
\cline { 2 - 5 } & верхняя & нижняя & абс. & $\%$ \\
\hline Резцы & 29 & 20 & 49 & 24,5 \\
\hline Клыки & 12 & 6 & 18 & 9,0 \\
\hline Премоляры & 35 & 31 & 66 & 33,0 \\
\hline Моляры & 35 & 32 & 67 & 33,5 \\
\hline Итого & 111 & 89 & 200 & 100 \\
\hline
\end{tabular}

Анализ данных таблицы 2 показал, что чаще с острыми явлениями в периодонте пациенты обращались к врачу с патологией премоляров $(33,0 \%)$ и моляров $(33,5 \%)$. 
В каждой группе были применены пять комплексов лечебных воздействий - медикаментозный, физический, (или без него), воздействие на периодонт составом пломбировочных материалов традиционным и отсроченным методами (таблица 3).

Таблица 3

Распределение больных с обострившимися хроническими гранулирующими (ОХВГрП), гранулематозными (ОХВГП) периодонтитами в зависимости от комплекса лечебных воздействий

\begin{tabular}{|l|c|c|c|c|c|}
\hline Подгруппа & $\begin{array}{c}\text { Метод } \\
\text { лечения }\end{array}$ & $\begin{array}{c}\text { Количе } \\
\text { ство } \\
\text { зубов }\end{array}$ & $\begin{array}{c}\text { Медикаментозная } \\
\text { обработка } \\
\text { корневых каналов }\end{array}$ & $\begin{array}{c}\text { Физическое } \\
\text { воздействи } \\
\text { е }\end{array}$ & $\begin{array}{c}\text { Эндодонти- } \\
\text { ческие } \\
\text { пломбировочные } \\
\text { материалы }\end{array}$ \\
\hline $1,6,11,16$ & ТР & 40 & $0,2 \%$ РХГ & - & ЭВ \\
\hline $2,7,12,17$ & ТР & 40 & $0,2 \%$ РВС & - & ВСП №1 \\
\hline $3,8,13,18$ & ТР & 40 & $0,2 \%$ РВС & У3 & ВСП №1+ГШ \\
\hline $4,9,14,19$ & ТР & 40 & $0,2 \%$ РВС & БТ+У3 & ВСПОИ № 2 + ГШ \\
\hline $5,10,15,20$ & ОТ & 40 & $0,2 \%$ РВС & БТ+ У3 & $\begin{array}{l}\text { ОТ «Кальсепт » } \\
\text { ВСПОИ № 2 + ГШ }\end{array}$ \\
\hline Итого & & 200 & & & \\
\hline
\end{tabular}

У больных 1, 6, 11 и 16 подгрупп с различными формами верхушечного периодонтита лечебный комплекс состоял из медикаментозной обработки корневых каналов $0,2 \%$ раствором хлоргексидина (РХГ) и пломбирования их «Эвгедентом» традиционным методом.

В подгруппах 2, 7, 12 и 17 с различными формами острых и обострившихся верхушечных периодонтитов лечебный комплекс состоял из медикаментозного воздействия на микрофлору макро- и микроканалов зубов антисептиком «Велтосепт» (РВC), каналы пломбировались предложенной нами велтосепт-пастой (ВСП № 1) традиционным методом.

Пациентам 3, 8, 13 и 18 подгрупп с различными формами верхушечных периодонтитов медикаментозную обработку проводили 0,2\% раствором велтосепта (BC) и ультразвуком (УЗ) внутриканально, корневые каналы пломбировали велтосепт-пастой № 11 с гуттаперчевыми штифтами традиционным методом.

В подгруппах 4, 9, 14, 19 с различными формами острых и обострившихся хронических верхушечных периодонтитов лечебный комплекс состоял из медикаментозной обработки системы макро- и 
микроканалов озвученным раствором $0,2 \%$ велтосепта и воздействия света «Bioptron», каналы пломбировались велтосепт-пастой с остеоиндуцином (ВСПОИ № 2) и гуттаперчевыми штифтами традиционным методом.

В подгруппах 5, 10, 15 и 20 с различными формами острых и обострившихся периодонтитов применялся отсроченный (OT) метод лечения комплексом, состоящим из медикаментозной обработки корневых каналов 0,2\% раствором велтосепта и ультразвуком внутриканально в комплексе с воздействием биостимулирующего света «Bioptron» чрезкожно. Система каналов пломбировалась временно материалом «Кальсепт», постоянно велтосепт-пастой с остеоиндуцином и гуттаперчевыми штифтами.

\subsection{2. Дезинфицирующее средство - антисептик «Велтосепт»}

«Велтосепт» представляет собой бесцветную жидкость, готовую к применению (рис. 1). В качестве действующего вещества содержит клатрат четвертичного аммониевого соединения с карбамидом $(0,1 \%)$ и изопропиловый спирт (70\%). По параметрам острой токсичности по ГОСТ 12.1.007-76 средство «Велтосепт» относится к 4-му классу малоопасных соединений при введении в желудок и нанесении на кожу.

«Велтосепт» - это универсальный, высокоэффективный, многофункциональный антисептик на основе экологически чистой субстанции. Средство не обладает местнораздражающим, кожнорезорбтивным и сенсибилизирующим действием. Средство «Велтосепт» обладает антимикробной активностью в отношении грамположительных и грамотрицательных бактерий (включая возбудителей туберкулеза, внутрибольничных инфекций), дрожжеподобных грибов рода Кандида, вирусов (в том числе возбудителей гриппа, острых респираторных вирусных инфекций, парентеральных вирусных гепатитов, ВИЧ-инфекций, герпеса, ротавирусных гастроэнтеритов, энтеровирусных инфекций гепатита $\mathrm{A}$, полиомиелита), особо опасных инфекций (чума, холера, сибирская язва). Средство обладает пролонгированным антимикробным действием не менее 3 
часов. Метод применения: смазывание, орошение, промывание. Применяется для обработки кожи операционного и инъекционного полей, рук хирургов и работников детских учреждений, стоматологического инструментария.

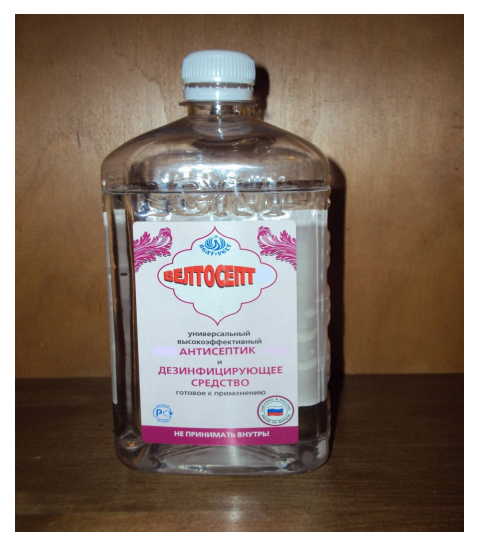

Рис.1. Антисептик «Велтосепт»

Средство дезинфицирующее - антисептик «Велтосепт», производство НПО «Велт» (Оренбург, Россия), свидетельство о государственной регистрации от 26.12.2006г. № 77. 99. 36. 2. у. 14304. 12. 06 на основании дезинфектологической экспертизы Центрального Научно-исследовательского института эпидемиологии - г. Москва.

\subsection{3 Новый пьезо-скалер «Amdent US 30 D» - мировой лидер ультразвуковой технологии}

Ультразвук оказывает биологическое воздействие: антибактериальное, противовирусное, фунгицидное, антиэкссудативное, абластическое, стимулирующее. Преимущества при использовании УЗ: бесконтактная очистка корневой поверхности, антимикробный эффект озвученных ирригационных растворов, возможность проникновения в труднодоступные места (плохо проходимые каналы и микроканалы). Ультразвуковой аппарат «Amdent US 30 D» обеспечивает полноценную санацию корневых каналов зубов в среде ирриганта «Велтосепт» (рис.2). «Amdent US 30 D» новый пьезо-скалер фирмы «Amdent», он простой и компактный, специально имеет функцию для работы в корневом канале. Прибор оснащен кнопкой для эндодонтии, которая сокращает выход мощности на 50\%, он сам переключается на работу в режиме эндодонтического инструмента, имеет три 
быстросъемных наконечника эндо W 70/70, эндо W 90/90, эндо W 110/110 держатели инструмента для корневого канала с/без жидкости, в режиме эндодонтии 10-50\%, в режиме скалера 10-30\%. Частота 24-28кГц.

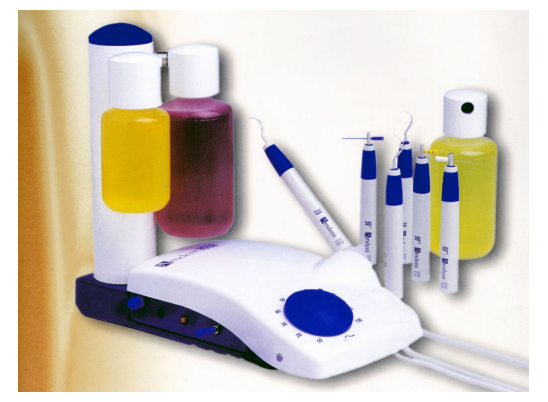

Pис.2 Aппарат «Amdent US 30 D»

Использование аппарата в лечебном процессе облегчает и ускоряет прохождение и расширение корневых каналов. Озвучивание велтосепта в канале обеспечивает разрушающее действие на клеточные оболочки бактерий, запускает химические реакции в среде ирриганта, что способствует дезинфекции канала и растворению органических соединений.

\subsection{4. Биостимулирующий свет «Bioptron»}

Для купирования воспалительного процесса в тканях периодонта нами применен прибор «Bioptron Compact III» (рисунок 3). Основным элементом светолечения «Bioptron» является оптическая трубка с галогеновой лампой в качестве источника света, по своим спектральным характеристикам близкой к солнечному, но без ультрафиолетовой составляющей. Мощность галогеновой лампы 20 ВТ, длина волны - 480-3400 нм, степень поляризации $>95 \%$ (590-1550 нм), удельная мощность - 40 мВт/см², плотность потока световой энергии в минуту - 2,3 Дж/см². Прибор соответствует требованиям стандарта 93/42/EЕC.

Использование светотерапии «Bioptron», спектром которого является комбинация из видимого света и инфракрасного излучения в стоматологии изучено недостаточно, свет, излучаемый прибором «Bioptron» - поляризован, его световые волны распространяются в параллельных плоскостях. Степень 
поляризации света «Bioptron» достигает 95\%. Свет - полихроматичен. В отличие от лазерного света, содержащего одну длину волны, он обладает широким спектральным составом, включая видимый свет и, частично, инфракрасное излучение.

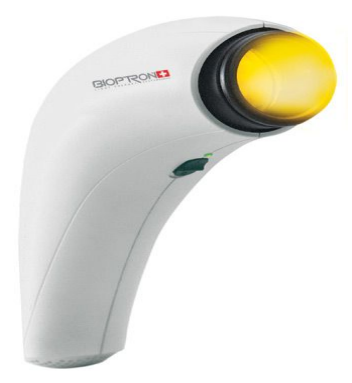

Рис.3. Aппарат «Bioptron»

Электромагнитный спектр полностью исключает ультрафиолетовые волны. Методика применения: при острых явлениях в периодонте после проведения инструментальной и медикаментозной обработки корневых каналов и прекращения оттока экссудата в комплекс лечебных воздействий включался свет «Bioptron». Свет аппарата «Bioptron» использовали чрезкожно на область проекции верхушек корней причинного зуба на 2-10 минут во второе посещение. В зависимости от тяжести воспалительного процесса сеанс светотерапии составлял от 3-7 процедур. А также его использовали после пломбирования корневых каналов зубов с целью профилактики осложнений.

\subsection{5. Эндодонтические пломбировочные материалы, стимулирующие остеогенез}

В работе применялись различные пломбировочные материалы, как традиционные («Эвгедент», содержащий оксид цинка, сульфат бария и эвгенол), так и предложенные нами на основе антисептика «Велтосепт»:

- № 1 Велтосепт-паста (оксид цинка 0,6 г, сульфат бария 0,2 г, велтосепт 0,1 мл, масло персиковое 0,3 мл);

- № 2 Велтосепт-паста с гидроксиапатитом (оксид цинка 0,6 г, сульфат бария 0,2 г, велтосепт 0,1 мл, масло персиковое 0,3 мл, остеоиндуцин 0,2 г). 
Остеоиндуцин - новейшая разработка нанотехнологии в стоматологии НКФ «Омега-Дент», Россия. Остеопластический материал на основе аморфного нанодисперсного резорбируемого гидроксиапатита кальция для восстановления дефектов костной ткани (рис. 4).

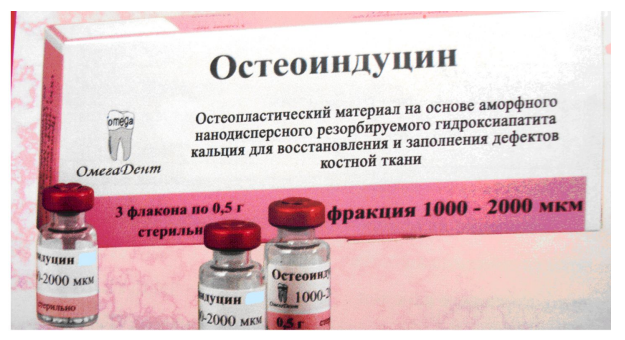

Рис.4. Материал «Остеоиндуцин»

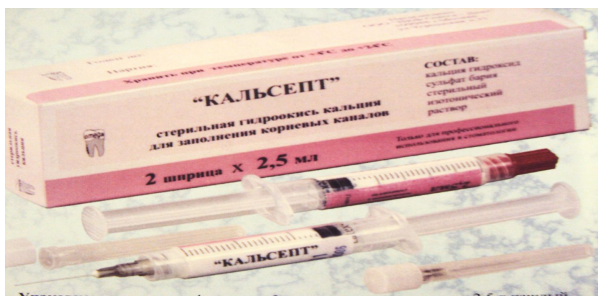

Рис.5. Материал для временного пломбирования корневых каналов «Кальсепт»

Препарат «Остеоиндуцин» может применяться в качестве остеопластического материала, оптимизирующего регенерацию костной ткани. Корневые каналы пломбировались вышеназванными эндодонтическими пастами традиционным методом с гуттаперчевыми штифтами методом латеральной конденсации.

В подгруппах 15 и 20 с деструктивными формами хронических периодонтитов применялся отсроченный метод лечения для пролонгированного действия и подготовку корневых каналов проводили соответственно традиционному методу $\mathrm{c}$ последующей временной обтурацией корневых каналов отечественным эндодонтическим материалом «Кальсепт» на основе гидроокиси кальция (рис. 5). Его состав: кальция гидроксид, сульфат бария, стерильный изотонический раствор. Материал расфасован в 2 пластиковых шприца, в комплекте с 20 специально стерильными канюлями. Через канюлю или инъекционную иглу материал вводился в корневой канал и равномерно распределялся на всем протяжении корневого канала с помощью гуттаперчевых штифтов или каналонаполнителя, затем удалялся избыток пасты с устья корневого канала и накладывалась пломба из стеклоиономерного цемента на 4 недели. Затем проводили замену «Кальсепт» на постоянную корневую пломбу - велтосептпасту № 2 с остеоиндуцином и гуттаперчевыми штифтами. 


\subsection{6 Критерии клинической эффективности проводимого лечения}

Эффективность различных способов лечения острых и обострившихся процессов в периодонте и влияние их на репаративный процесс остеогенеза определялись путем сравнительного анализа клинических и рентгенологических данных в ближайшие 3-5 дней и отдаленные (через 3, 6, 12 месяцев) сроки наблюдения после пломбирования корневых каналов. Ближайшие результаты с благоприятным клиническим течением считались те, когда больные не предъявляли жалоб спустя сутки после лечения. При наличии жалоб на ноющую боль, боль при накусывании на причинный зуб, наличие гиперемии, отека переходной складки слизистой оболочки полости рта, болезненность при пальпации спустя трое суток после окончания лечения - такие результаты трактовались как неблагополучные.

Степень заполнения корневых каналов зубов оценивались по данным рентгенограмм, которые выполнялись сразу после их пломбирования.

\subsection{7. Рентгенологическое исследование альвеолярных отростков челюстей}

Метод рентгенографии широко используется в стоматологии для диагностики патологических очагов в костных структурах и наблюдения за динамикой эффективности проводимого лечения. $\mathrm{B}$ нашей работе применялся рентгенологический аппарат 5Д2 (Viniodent 55/1 Chirana) с фиксированной экспозицией рентгеновских лучей.

Использовался внутриротовой контактный метод, отобраны качественные снимки, которые проводились каждому больному до и после лечения, а также спустя 3, 6, 12 месяцев. Использование данного рентгеновского аппарата позволило повысить достоверность диагностики структурных изменений в околоверхушечном периодонте под воздействием различных лечебных комплексов, применяемых в работе. 
2.3. Материалы и методы определения цитохимических показателей у больных с различными формами верхушечных периодонтитов

\subsection{1. Методика забора материала десневого желобка для оценки клеточного состава}

Для оценки состояния местного иммунитета проводили изучение клеточного состава материала десневого желобка. При этом в получаемом содержимом определяли количество эпителиальных клеток, нейтрофилов и лимфоцитов.

Забор материала десневого желобка осуществляли с помощью специальной микропипетки. Полученный материал вносили в пробирку, содержащую 1,5-2 мл забуференного физиологического раствора (pH 7,3), и центрифугировали при 2000 оборотов/мин в течение 10 минут. Надосадочную жидкость убирали при помощи пастеровской пипетки, осадок ресуспензировали в 0,1 мл забуференного физиологического раствора и использовали для приготовления мазков. Мазок высушивали, фиксировали метанолом и окрашивали по Романовскому-Гимза. Мазки просматривали в световом микроскопе при увеличении (90x), определяя количество эпителиальных клеток (ЭК), нейтрофилов $(\mathrm{H})$ и лимфоцитов (Л), выражая его в процентах на 100 выявленных клеток.

2.3.2. Приготовление мазков и забор материала для определения активности ферментных систем полиморфноядерных лейкоцитов

Тонкие предметные стекла тщательно обрабатывали мыльным раствором, промывали в проточной воде и ополаскивали последовательно в двух порциях дистиллированной воды. Сухие стекла погружали в смесь спирта и эфира (1:1) на 7 суток. Тщательно протертые стекла заворачивали в бумагу для хранения и дальнейшего использования в течение одного месяца.

Мазок готовили из капиллярной крови, взятой у пациента до и после лечения, при этом выполняли прокол десны в области пораженного зуба и симметрично со здоровой стороны. При взятии крови первую каплю удаляли стерильной ватой, вторую забирали с помощью микропипетки и наносили на 
подготовленное предметное стекло. Мазок делали плавным скользящим движением шлифовального стекла, приставленного к предметному стеклу под углом $45^{0}$, равномерно распределяя кровь по поверхности. Использовали мазки средней толщины, не доходящие до краев предметного стекла. Мазки высушивали на воздухе и фиксировали по соответствующей методике в зависимости от выявляемого фермента.

\subsection{3. Определение миелопероксидазы}

Для определения в клетках крови миелопероксидазы необходимы заранее приготовленные следующие растворы:

- раствор спирт-формола: 10 мл 40\% нейтрального формалина смешивали с 90 мл $96^{0}$ этилового спирта; раствор использовали многократно, хранили при температуре $(4 \pm 1)^{0} \mathrm{C}$;

- 3\% раствор перекиси водорода: к 2,7 мл дистиллированной воды добавляли 0,3 мл пергидроля;

- инкубационная среда: 200 мг бензидина растворяли в 20 мл $96^{0}$ этилового спирта и добавляли 30 мл дистиллированной воды (раствор хранили при комнатной температуре). Непосредственно перед использованием к 50 мл раствора добавляли 0,1 мл 3\% свежеприготовленной перекиси водорода.

Порядок проведения реакции. Сухие мазки фиксировали в спиртовоформалиновом растворе в течение одной минуты, после чего промывали дистиллированной водой и просушивали на воздухе. Высушенные мазки помещали в инкубационную среду при комнатной температуре на 7-10 минут, затем промывали в водопроводной воде и высушивали на воздухе. Для окрашивания ядер нейтрофилов мазки инкубировали в $0,01 \%$ водном растворе азура II в течение 15-20 секунд, затем промывали в проточной воде и высушивали на воздухе. Миелопероксидазу выявляли по наличию в цитоплазме нейтрофилов гранул желтовато-коричневого цвета. 


\subsection{4. Определение лизосомальных катионных белков}

Для определения в клетках крови лизосомальных катионных белков необходимы заранее приготовленные растворы:

- 0,2М раствор триса: 2,42 триса растворяли в дистиллированной воде до объема 100 мл;

- метаноловый трис-буфер: 25 мл 0,25М триса смешивали с 22,5 мл 0,1 H раствора НСІ и добавляли 52,5 мл метанола;

- спиртовый забуференный раствор прочного зеленого (рН 8.1-8.2): 100мг прочного зеленого растворяли в 100 мл метанолового трис-буфера;

- инкубационная среда (хранили до 4-х месяцев): 100 мл метанолового трис-буфера смешивали со 100 мл спиртового забуференного раствора прочного зеленого. Через сутки рН раствора доводили до 8,1-8,2 с помощью $0,1 \mathrm{H}$ раствора $\mathrm{NaOH}$ или $0,1 \mathrm{H}$ раствора $\mathrm{HCI}$;

- 0,25\% раствора азура II: 250 мг азура II растворяли в дистиллированной воде, доводили объем до 100 мл (хранили при температуре $4 \pm 1^{0} \mathrm{C}$ ).

При проведении реакции сухие мазки крови фиксировали в метаноле в течение 5 минут, затем помещали в инкубационную среду на 35 минут при комнатной температуре, после чего промывали дистиллированной водой и высушивали. Для окрашивания ядер нейтрофилов мазки инкубировали в 0,25\% растворе азура II в течение 15-20 секунд, промывали в дистиллированной воде и высушивали.

Микроскопию препаратов производили с оранжевым фильтром. Окрашивание цитоплазмы нейтрофилов в ярко-зеленый цвет свидетельствовало о наличии катионных белков.

\subsection{5. Определение кислой фосфатазы}

Для определения в клетках крови кислой фосфатазы необходимы заранее приготовленные растворы:

- раствор спирт-формола: 10 мл 40\% нейтрального формалина смешивали с 90 мл $96^{0}$ этилового спирта; 
- 0,1H раствор ацетата натрия: 6,8 г $\mathrm{CH}_{3} \mathrm{COONa}_{3} \mathrm{H}_{2} \mathrm{O}$ растворяли в дистиллированной воде до объема 500 мл;

- 2\% раствор фуксина: 2 г фуксина основного растворяли в $1 \mathrm{H}$ растворе соляной кислоты до объема 100 мл;

- $1 \mathrm{H}$ раствор соляной кислоты: 8,08 мл концентрированной соляной кислоты растворяли в дистиллированной воде до объема 100 мл;

- 4\% раствор азотистокислого натрия: 4 г азотистокислого натрия растворяли в дистиллированной воде до объема 100 мл;

Все растворы хранили при температуре $(4 \pm 1)^{0} \mathrm{C}$ в течение одного месяца. Непосредственно перед употреблением готовили:

- раствор А: 20 мг нафтола Asbi-фосфата растворяли в 0,5мл демитилформальдегида и добавляли 40 мл холодного $0,1 \mathrm{H}$ раствора ацетата натрия;

- раствор В: 8 капель 2\% раствора фуксина на соляной кислоте смешивали с 8 каплями азотокислого натрия.

Раствор А смешивали с раствором В, устанавливали $\mathrm{pH}$ 5,2-5,4 при помощи $1 \mathrm{H}$ раствора соляной кислоты. При проведении реакции сухие мазки фиксировали в растворе спирт-формола в течение 30 секунд, после чего промывали в проточной воде и высушивали на воздухе.

Затем помещали в инкубационную среду на 2 часа при температуре $37^{0} \mathrm{C}$, после чего промывали в дистиллированной воде и высушивали на воздухе. Для окрашивания ядер нейтрофилов мазки крови помещали в $0,5 \%$ раствора метилового зеленого на 30 секунд. Окрашивание цитоплазмы в красный цвет свидетельствовало о наличии кислой фосфатазы, ядра при этом окрашивались в зеленый цвет.

\subsection{6. Определение щелочной фосфатазы}

Для определения в клетках крови щелочной фосфатазы необходимы заранее приготовленные растворы: 
- трис-буфер: 2,42 трис-оксиметила аминометана растворяли в 50 мл дистиллированной воды, добавляли 18,9 мл 1 Н раствора соляной кислоты и затем дистиллированную воду до объема 100 мл (pH 9,6);

- раствор спирт-формола: 10 мл 100\% нейтрального формалина растворяли в 90 мл абсолютного метилового спирта. Раствор использовали многократно, хранили при температуре $(4 \pm 1)^{0} \mathrm{C}$;

- 0,01\% раствор азура II: 100 мг азура II растворяли в дистиллированной воде, доводили объем до 100 мл (хранили при температуре $(4 \pm 1)^{0} \mathrm{C}$;

- инкубационная среда: 35 мг нафтилфосфата натрия смешивали с 35 мг прочного синего RR и добавляли 35 мл трис-буфера. Раствор готовили перед употреблением.

При проведении реакции сухие мазки фиксировали в растворе спиртметанола в течение 30 секунд, после чего промывали в проточной водой и высушивали на воздухе. Мазки помещали в инкубационную среду на 20 секунд, после чего промывали проточной водой и высушивали на воздухе. Для окрашивания ядер нейтрофилов мазки инкубировали в $0,01 \%$ растворе азура II в течение 20 секунд, промывали водопроводной водой и высушивали. Содержащаяся в цитоплазме клеток щелочная фосфатаза окрашивалась при этом в коричневый цвет.

Полученные цитоэнзимохимические данные оценивали полуколичественным методом. При иммерсионной микроскопии мазков определяли степень интенсивности окраски в 100 клетках крови следующим образом:

- нулевая степень - отсутствие окраски цитоплазмы;

- первая степень - наличие единичных гранул в цитоплазме или ее слабое диффузное прокрашивание;

- вторая степень - исследуемое вещество заполняет почти полностью всю клетку;

- третья степень - интенсивно окрашенные гранулы заполняют всю цитоплазму, часто прикрывая ядро. 


\section{ГЛАВА 3. РЕЗУЛЬТАТЫ МИКРОБИОЛОГИЧЕСКИХ ИССЛЕДОВАНИЙ}

Применение данного исследования наряду с клиническими, диктовалось необходимостью определения чувствительности микрофлоры корневых каналов к антисептику «Велтосепт». Средство «Велтосепт», согласно характеристике препарата, обладает антимикробной активностью в отношении грамположительных и грамотрицательных бактерий, включая возбудителей туберкулеза, дрожжеподобных грибов рода Кандида, вирусов, в том числе возбудителей гриппа, острых респираторных вирусных инфекций, парентеральных вирусных гепатитов, ВИЧ-инфекций, герпес, ротавирусных гастроэнтеритов, энтеровирусных инфекций, гепатита $\mathrm{A}$, полиомиелита, особо опасных инфекций - холера, чума, сибирская язва.

Возможности применения «Велтосепт»в качестве дезинфектанта при лечении воспалительных заболеваний периодонта не изучена. В связи с этим первоначально нами было изучено антимикробное действие «Велтосепта»на тест-штаммах микроорганизмов - основных представителей нормальной микрофлоры ротовой полости.

В экспериментах были использованы 50 штаммов микроорганизмов, из них: Staphylococcus - 20, Streptococcus - 20, E.coli - 10. Размножение культур осуществляли в условия термостата при температуре $37^{0} \mathrm{C}$ в течение 24-48 часов на плотных питательных средах.

\section{1. Результаты определения минимальной подавляющей концентрации «Велтосепт» в опытах на плотных питательных средах}

При определении МПК велтосепта в качестве исходного был использован патентованный раствор изучаемого препарата, из которого готовились последовательные двукратные разведения данного препарата в физиологическом растворе, получая соответствующие концентрации (20; 10 ; $5 ; 2,5 ; 1,25 ; 0,62 ; 0,31)$. В полученные растворы вносили по 0,1 мл суспензии двухсуточных агаровых культур тест-штаммов в 0,9\% (растворе натрия хлорида в объеме среды (25 мл) получали следующие его концентрации в питательном агаре: 0,$2 ; 0,1 ; 0,05 ; 0,0125 ; 0,0062 ; 0,0031 ; 0,0061 ; 0,0008 \%$. 
По данным полученным в результате предварительных экспериментов, проведенных на ограниченном количестве (по одному штамму представителей каждого рода) тестовых культур, было установлено, что при их посеве на плотную питательную среду с содержанием велтосепта $0,0031 \%$ и ниже в максимально использованной концентрации ( $1 \times 10^{9}$ м.к./мл) не наблюдалось подавления роста контрольных микроорганизмов. В связи с этим для дальнейших исследований в опытах на плотных питательных средах мы ограничились оценкой дезинфекционных свойств в отношении тест-штаммов следующих концентраций велтосепта: 0,$2 ; 0,1 ; 0,05 ; 0,025$; 0,$0125 ; 0,0062 \%$.

Анализ полученных данных показал, что антимикробный эффект велтосепта определяется концентрацией антисептика, видом микробного агента и его посевной дозой. Независимо от концентрации велтосепта и используемых в экспериментах тест-штаммов наибольшая активность препарата была установлена при минимальных посевных дозах культур $\left(1 \times 10^{5}\right.$ м.к./мл), даже наименьшая из используемых концентраций антисептика $(0,0062 \%)$ обеспечивала подавление роста всех взятых в эксперимент штаммов микроорганизмов. Увеличение посевной дозы культур (1х10 7 и $1 \times 10^{9}$ м.к./мл) приводило к пропорциональному снижению антимикробной активности антисептика, которое наблюдалось в пределах каждой из используемых в экспериментах концентраций дезинфектанта.

Наибольшую чувствительность к антимикробному действию велтосепта проявляли штаммы кишечной палочки. Концентрация препарата, равная 0,05\%, для всех посевных доз данного микробного агента являлась его МПК. Эффект характеризовался стойким бактерицидным действием, что устанавливалось при длительном (в течение 14 суток) выдерживании посевов в оптимальном температурном режиме $\left(37^{\circ} \mathrm{C}\right)$.

В меньшей степени антисептические свойства велтосепта были выражены в отношении представителей рода Staphylococcus. Минимальная подавляющая концентрация препарата в отношении данных представителей 
составляла $0,1 \%$. Повышение концентрации велтосепта до 0,2\% расширяло спектр его активности и в отношении представителей рода Streptococcus. Как в отношении штаммов кишечной палочки антимикробный эффект в отношении штаммов стафилококков и стрептококков характеризовался стойким бактерицидным действием для установленных МПК препарата.

Таким образом, проведенные эксперименты позволили установить, что активность велтосепта различна в отношении используемых тест-штаммов микроорганизмов, при этом показатели антимикробного действия обратно пропорциональны величине посевной дозы тест-штаммов. Эффект препарата несколько ниже в отношении стрептококков (МПК - 0,2\%), в большей степени он выражен в отношении штаммов кишечной палочки (МПК 0,05\%) и средняя степень выраженности антимикробного действия (МПК $0,1 \%$ ) зарегистрирована для штаммов стафилококка.

Суммировав полученные результаты, можно констатировать, что установленная минимальная подавляющая концентрация велтосепта в экспериментах на плотных питательных средах в отношении изучаемых тестштаммов составляет 0,2\%. При этом велтосепт в данной концентрации оказывает стойкий бактерицидный эффект.

\section{2. Результаты определения минимальной подавляющей концентрации велтосепта суспензионным методом.}

Учитывая описанные выше результаты, в данной серии экспериментов концентрация антисептика была ограничена более узким диапазоном и составляла: $0.2 ; 0.1 ; 0,05 ; 0,025 \% \%$. Разведение препарата осуществляли аналогичным образом в физиологическом растворе, после чего в полученные растворы вносили взвеси культур используемых тест-штаммов. Время экспозиции составляло 30, 60 и 90 секунд. Поскольку наибольший интерес представляло определение влияния антисептика на высокие концентрации микробных агентов, то в данной серии экспериментов была использована максимальная посевная доза изучаемых культур, которая составляла $1 \times 10^{9}$ м.к./мл. Опыты проводились в трех повторах. 
Таблица 4

Определение активности велтосепта в отношении тест-штаммов микроорганизмов

\begin{tabular}{|c|c|c|c|c|c|c|c|c|c|c|c|c|c|c|c|c|c|c|c|c|c|c|c|}
\hline & \multicolumn{22}{|c|}{ Антимикробное действие препарата в разведении препарата при экспозици(секунды) } \\
\hline & & \multicolumn{3}{|c|}{ цельный } & \multicolumn{3}{|c|}{$1: 2$} & \multicolumn{4}{|c|}{$1: 4$} & \multicolumn{3}{|c|}{$1: 8$} & \multicolumn{3}{|c|}{$1: 16$} & \multicolumn{3}{|c|}{$1: 32$} & \multicolumn{3}{|c|}{$1: 64$} \\
\hline & & 30 & 60 & 90 & 30 & 60 & 90 & & & 60 & 90 & 30 & 60 & 90 & 30 & 60 & 90 & 30 & 60 & 90 & 30 & 60 & 90 \\
\hline \multirow{10}{*}{$\begin{array}{l}\overline{0} \\
\overline{0} \\
\end{array}$} & K12 & - & - & - & - & - & - & t & & + & - & + & + & + & + & + & + & + & + & + & + & + & + \\
\hline & ATCC25922 & - & - & - & - & - & - & 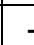 & & - & - & + & - & - & + & + & - & + & + & + & + & + & + \\
\hline & 870 & - & - & - & - & - & - & - & & - & - & - & - & - & + & + & - & + & + & + & + & + & + \\
\hline & $13 / 30$ & - & - & - & - & - & - & t & & + & - & + & + & + & + & + & + & + & + & + & + & + & + \\
\hline & $63 / 75$ & - & - & - & - & - & - & $t$ & & + & - & + & + & + & + & + & + & + & + & + & + & + & + \\
\hline & 544 & - & - & - & - & - & - & $t$ & & + & - & + & + & + & + & + & + & + & + & + & + & + & + \\
\hline & 19 & - & - & - & - & - & - & - & & - & - & + & - & - & + & + & - & + & + & + & + & + & + \\
\hline & A-422 & - & - & - & - & - & - & $t$ & & + & - & + & + & + & + & + & + & + & + & + & + & + & + \\
\hline & 82 & - & - & - & - & - & - & t & & + & - & + & + & + & + & + & + & + & + & + & + & + & + \\
\hline & K-24 & - & - & - & - & - & - & + & & + & - & + & + & + & + & + & + & + & + & + & + & + & + \\
\hline \multirow{20}{*}{ 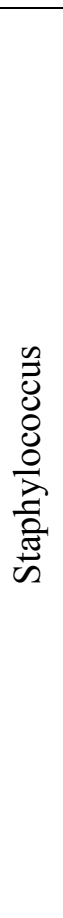 } & 6 & - & - & - & - & - & - & - & & - & - & + & - & - & + & + & - & + & + & + & + & + & + \\
\hline & 707 & - & - & - & - & - & - & - & & - & - & + & - & - & + & + & - & + & + & + & + & + & + \\
\hline & ATCC25923 & - & - & - & - & - & - & - & & - & - & + & - & - & + & + & - & + & + & + & + & + & + \\
\hline & Cowan 5 & - & - & - & - & - & - & - & & - & - & - & - & - & + & + & - & + & + & + & + & + & + \\
\hline & 61 & - & - & - & - & - & - & - & & - & - & - & - & - & + & + & - & + & + & - & + & + & + \\
\hline & 13 & - & - & - & - & - & - & - & & - & - & + & - & - & + & + & - & + & + & + & + & + & + \\
\hline & 15 & - & - & - & - & - & - & + & & - & - & + & + & - & + & + & + & + & + & + & + & + & + \\
\hline & 41 & - & - & - & - & - & - & + & & - & - & + & + & - & + & + & + & + & + & + & + & + & + \\
\hline & 499 & - & - & - & - & - & - & + & & + & - & + & + & + & + & + & + & + & + & + & + & + & + \\
\hline & 543 & - & - & - & - & - & - & - & & - & - & - & - & - & + & - & - & + & - & - & + & + & + \\
\hline & 513 & - & - & - & - & - & - & - & & - & - & - & - & - & + & + & - & + & + & + & + & + & + \\
\hline & 645 & - & - & - & - & - & - & - & & - & - & + & - & - & + & + & - & + & + & + & + & + & + \\
\hline & 741 & - & - & - & - & - & - & 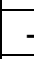 & & - & - & + & - & - & + & + & - & + & + & + & + & + & + \\
\hline & 418 & - & - & - & - & - & - & - & & 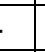 & - & - & - & - & + & - & - & + & - & - & + & + & - \\
\hline & C-460 & - & - & - & - & - & - & + & & 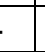 & - & + & + & + & + & + & + & + & + & + & + & + & + \\
\hline & C-477 & - & - & - & - & - & - & - & & 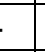 & - & - & - & - & + & - & - & + & + & - & + & + & + \\
\hline & C-488 & - & - & - & - & - & - & - & & . & - & - & - & - & + & - & - & + & + & - & + & + & + \\
\hline & P-504 & - & - & - & - & - & - & - & & 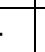 & - & + & - & - & + & + & - & + & + & + & + & + & + \\
\hline & C-529 & - & - & - & - & - & - & - & & . & - & - & - & - & - & - & - & + & - & - & + & + & - \\
\hline & C-535 & - & - & - & - & - & - & - & & - & - & - & - & - & + & - & - & + & + & - & + & + & + \\
\hline & 190 & - & - & - & - & - & - & - & & . & - & + & - & - & + & - & - & + & + & - & + & + & + \\
\hline & 383 & - & - & - & - & - & - & - & & 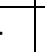 & - & + & - & - & + & + & - & + & + & + & + & + & + \\
\hline & 9640 & - & - & - & - & - & - & + & & - & - & + & + & - & + & + & + & + & + & + & + & + & + \\
\hline & C-654 & - & - & - & - & - & - & + & & + & - & + & + & + & + & + & + & + & + & + & + & + & + \\
\hline & C-669 & - & - & - & - & - & - & - & & 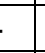 & - & - & - & - & - & - & - & + & + & - & + & + & + \\
\hline & 676 & - & - & - & - & - & - & - & & . & - & - & - & - & + & - & - & + & + & + & + & + & + \\
\hline & 697 & - & - & - & - & - & - & - & & . & - & + & + & - & + & + & + & + & + & + & + & + & + \\
\hline & 698 & - & - & - & - & - & - & - & & . & - & + & - & - & + & + & - & + & + & + & + & + & + \\
\hline $\overrightarrow{0}$ & 699 & - & - & - & - & - & - & - & & 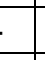 & - & + & - & - & + & + & - & + & + & + & + & + & + \\
\hline 8 & $68 / ! 2$ & - & - & - & - & - & - & - & & . & - & - & - & - & + & - & - & + & + & + & + & + & + \\
\hline : & $566 / 762$ & - & - & - & - & - & - & $t$ & & 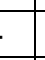 & - & + & + & - & + & + & + & + & + & + & + & + & + \\
\hline$\stackrel{\Xi}{E}$ & 1198 & - & - & - & - & - & - & - & & 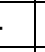 & - & + & + & - & + & + & + & + & + & + & + & + & + \\
\hline & $15 / 47$ & - & - & - & - & - & - & - & & 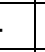 & - & + & - & - & + & + & - & + & + & + & + & + & + \\
\hline & 1199 & - & - & - & - & - & - & - & & . & - & + & - & - & + & + & - & + & + & + & + & + & + \\
\hline & $531 / 17$ & - & - & - & - & - & - & - & & . & - & - & - & - & - & - & - & + & - & - & + & + & - \\
\hline & $213 / ! 0$ & - & - & - & - & - & - & - & & 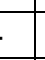 & - & + & + & - & + & + & + & + & + & + & + & + & + \\
\hline & $1(\mathrm{CO})$ & - & - & - & - & - & - & - & & 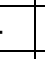 & - & + & + & - & + & + & + & + & + & + & + & + & + \\
\hline & $1056 / 1$ & - & - & - & - & - & - & - & & 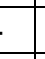 & - & - & - & - & - & - & - & + & + & - & + & + & + \\
\hline & $298 / 22$ & - & - & - & - & - & - & - & & . & - & - & - & - & + & - & - & + & + & + & + & + & + \\
\hline & $300 / 31$ & - & - & - & - & - & - & - & & & - & + & - & - & + & + & - & + & + & + & + & + & + \\
\hline
\end{tabular}


Было показано, что характер антимикробного действия велтосепта зависел от длительности воздействия (30, 60 и 90 секунд) препарата на микробную взвесь. Во всех трех сериях наблюдений полученные результаты были аналогичными, что позволило использовать именно минимальную экспозицию (30 секунд) в дальнейших экспериментальных исследованиях (табл. 4).

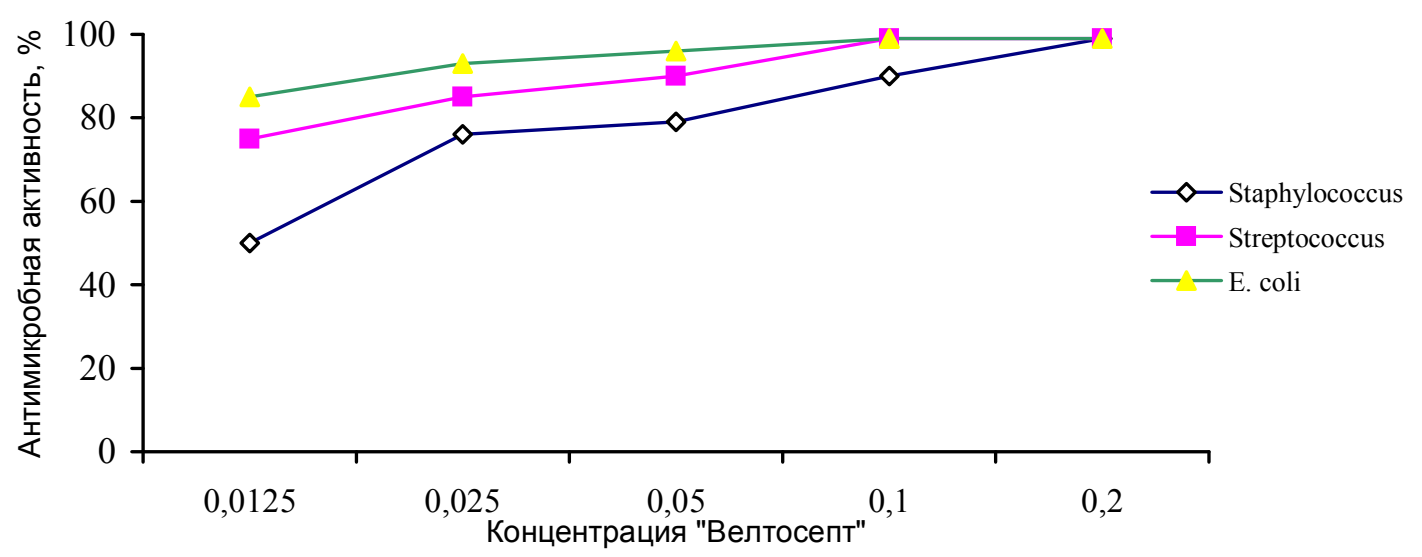

Рис. 6. Антимикробная активность велтосепта в отношении нормальной микрофлоры ротовой полости

Анализ полученных данных показал, что МПК, определенная в экспериментах на плотных питательных средах, соответствовала таковой, полученной с применением суспензионного метода. Для посевной дозы, равной $1 \times 10^{9}$ м.к./мл, МПК велтосепта составляла 0,2\%, которая обеспечивала подавление роста всех используемых штаммов стрептококка. При этом штаммы кишечной палочки проявляли наибольшую чувствительность к препарату (МПК-0,05\%), штаммы стафилококка по чувствительности к апробируемому антисептику занимали промежуточное положение (МПК- 0,1\%). При использовании суспензионного метода удалось подтвердить установленный ранее уровень МПК велтосепта в отношении обычных представителей микрофлоры ротовой полости, который составлял $0,2 \%$ (рис. 6 ).

Проведенные эксперименты, выполненные в различных условиях (плотные питательные среды, суспензионный метод), позволили показать, что велтосепт обладает выраженной антимикробной активностью в 
отношении микрофлоры ротовой полости (стафилококки, стрептококки, кишечная палочка), активность препарата зависит от вида микробного агента и концентрации антисептика.

МПК препарата составляет 0,2\%, которая обеспечивает бактерицидный эффект в отношении всех изученных штаммов микроорганизмов, независимо от их концентрации.

\section{3. Результаты изучения микрофлоры корневых каналов зубов у больных с верхушечными периодонтитами}

Инфекция корневых каналов в основном обеспечивается грамотрицательной анаэробной флорой. В экспериментах на клиническом материале, полученном от 20 больных с различными формами апикального периодонтита, было проведено предварительное изучение состава микробной флоры содержимого каналов. Для этого турунды с материалом из корневых каналов помещали в 1 мл 0,9\% раствора натрия хлорида, проводили 10кратные последовательные разведения исходного материала $\left(10^{-1} ; 10^{-2}\right)$ и высевали на чашки с плотными питательными средами как нативный, так и разведенный материал.

При анализе микробного пейзажа содержимого корневых каналов первых исследованных проб было показано, что высев из нативных образцов давал сплошной рост как аэробной, так и анаэробной микрофлоры, который невозможно было идентифицировать. Реально оцениваемые результаты были получены при разведении исходного материала в 10 и 100 раз, поэтому в дальнейшем нами производились высевы только из разведенных образцов проб исходного материала. Из 20 клинических образцов содержимого корневых каналов был получен рост микрофлоры с преобладанием анаэробных микробных агентов.

По характеру роста и при бактериоскопическом исследовании можно было выделить несколько групп микроорганизмов:

- 1 группа - аэробные грамположительные кокки, расположенные в мазках изолировано или образующие скопления клеток в виде виноградной 
грозди, формирующие на используемых средах округлые колонии диаметром 3-4 мм золотистого, белого или лимонно-желтого цвета;

- 2 группа - аэробные грамположительные кокки, расположенные в мазках цепочками, формирующие мелкие, серовато-белые, слегка мутноватые колонии только на сывороточно-декстрозном агаре;

- 3 группа - анаэробные грамотрицательные кокки, формирующие в толще агара округлые белесоватые колонии диаметром 1-2 мм;

- 4 группа - аэробные грамотрицательные палочки, образующие на используемых средах выпуклые полупрозрачные сероватые колонии;

- 5 группа - анаэробные грамотрицательные палочки, формирующие на кровяном агаре выпуклые, непигментированные колонии.

Таблица 5

Микробная обсемененность содержимого корневых каналов у больных с апикальным периодонтитом

\begin{tabular}{|c|c|c|c|c|c|}
\hline \multirow[b]{2}{*}{$\begin{array}{l}\text { № } \\
\Pi \\
\mathrm{p} \\
\mathrm{o} \\
6\end{array}$} & \multicolumn{5}{|c|}{ Микроорганизмы } \\
\hline & $\begin{array}{c}\text { аэробные } \\
\text { грамположи- } \\
\text { тельные } \\
\text { кокки } \\
\text { (1 группа) }\end{array}$ & $\begin{array}{c}\text { аэробные } \\
\text { грамположите } \\
\text { льные кокки } \\
\text { (2 группа) }\end{array}$ & $\begin{array}{c}\text { анаэробные } \\
\text { грамотрица- } \\
\text { тельные кокки } \\
\text { (3 группа) }\end{array}$ & $\begin{array}{c}\text { аэробные } \\
\text { грамотрицательн } \\
\text { ые палочки } \\
\text { (4 группа) }\end{array}$ & $\begin{array}{c}\text { анаэробные } \\
\text { грамотрицате } \\
\text { льные } \\
\text { палочки } \\
\text { (5 группа) }\end{array}$ \\
\hline 1 & + & - & + & - & + \\
\hline 2 & - & + & - & - & - \\
\hline 3 & - & - & + & + & + \\
\hline 4 & - & - & + & - & + \\
\hline 5 & + & + & - & + & - \\
\hline 6 & - & + & - & - & - \\
\hline 7 & + & - & + & - & + \\
\hline 8 & - & + & - & - & - \\
\hline 9 & + & - & - & + & - \\
\hline 10 & - & - & + & - & + \\
\hline 11 & - & + & - & - & - \\
\hline 12 & - & + & - & - & - \\
\hline 13 & - & - & + & - & + \\
\hline 14 & - & - & + & - & + \\
\hline 15 & - & + & - & - & - \\
\hline 16 & + & - & - & + & - \\
\hline 17 & & - & + & - & + \\
\hline 18 & - & + & - & - & - \\
\hline 19 & - & - & + & - & + \\
\hline 20 & - & - & + & - & + \\
\hline
\end{tabular}


Микробная обсемененность каждой из изученных проб представлена в таблице 5.

Из данных таблицы 5 следует, что из 20 исследованных клинических образцов содержимого корневых каналов было выделено 37 штаммов микроорганизмов, среди которых аэробная микрофлора составила 45,94 (17 штаммов), анаэробная - 54,06 (20 штаммов).

В девяти пробах (45,00\%) были изолированы два типа микроорганизмов; в четырех наблюдениях (20,00\%) была установлена смешанная микрофлора, представленная тремя видами идентифицированных микроорганизмов как из групп аэробов, так и анаэробов; в остальных 7 пробах $(35,00 \%)$ выделены монокультуры.

Характер изолированной микрофлоры корневых каналов проб клинического материала больных с апикальным периодонтитом представлен на рисунке 7.

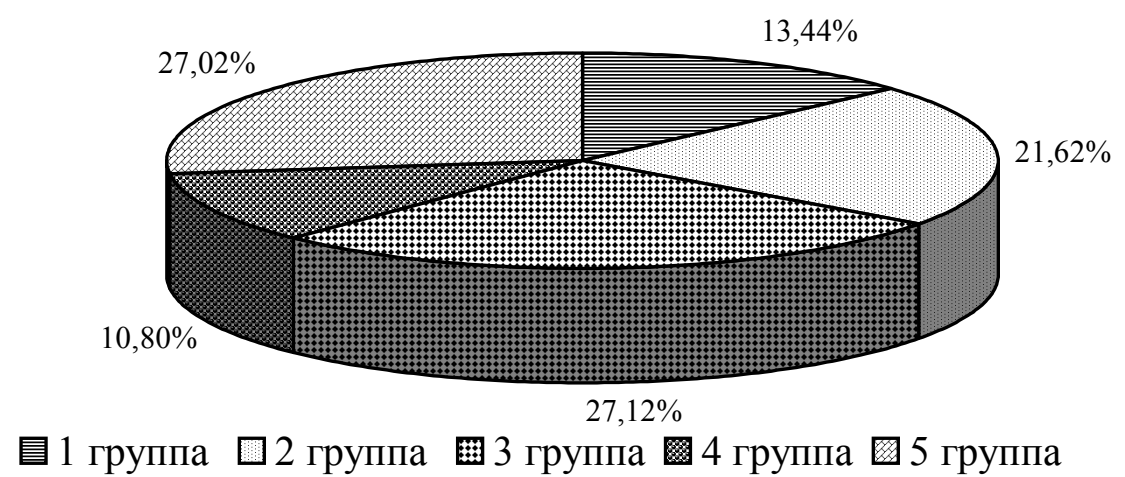

Обозначения: 1 группа - аэробные грамположительные кокки, 2 группа - аэробные грамположительные кокки, 3 группа - анаэробные грамотрицательные кокки, 4 группа - аэробные грамотрицательные палочки, 5 группа - анаэробные грамотрицательные палочки

Рис. 7 Микрофлора корневых каналов больных апикальным периодонтитом

Таким образом, в результате проведенных исследований был изучен микробный пейзаж корневых каналов у больных с острыми явлениями в апикальном периодонте, проведено деление выделенной микрофлоры по потребности в кислороде (аэробы, анаэробы) и осуществлена предварительная идентификация изолированных культур по морфологии 
микробной клетки (кокки, палочки), по тинкториальным и частично культуральным свойствам.

3.4. Результаты определения эффективности сочетанного действия велтосепта и физических факторов на микрофлору корневых каналов зубов у больных с верхушечными периодонтитами

Для сравнительной оценки эффективности применяемых методик санации корневых каналов зубов и купирования воспалительного процесса при лечении острых и обострившихся хронических периодонтитов были подобраны три группы больных:

- 1 группа (10 больных) с острыми явлениями в периодонте различного характера, для санации корневых каналов которых был использован 0,2\% $\mathrm{PBC}$;

- 2 группа (10 человек) - больные с периодонтитами различных форм, для санации корневых каналов зубов которых использовали различные концентрации РВС, а в последующем применяли воздействие ультразвука аппарата «Amdent US 30 D» внутриканально;

- 3 группа (10 человек) - больные с острыми и обострившимися хроническими верхушечными периодонтитами, для санации корневых каналов которых использовали различные концентрации РВС и воздействие чрезкожно света «Bioptron».

В качестве контроля для больных второй и третьей групп производили забор материала после обработки канала антисептиком, но до воздействия ультразвука и света «Bioptron». У всех трех групп больных длительность экспозиции турунды с антисептиком в полости канала составляла 30 секунд. Исследование клинического материала проводилось как описывалось выше, чтобы была вероятность выявления, как аэробной, так и анаэробной микрофлоры.

Проводимые исследования показали, что у больных первой группы и второй после воздействия ультразвуком внутриканально получены 100\% 
отрицательные результаты несмотря на снижения концентрации раствора велтосепта до $0,1 \%$.

В третьей группе у больных при обработке корневых каналов зубов 0,05\% раствором велтосепта для санации корневых каналов в семи наблюдениях выделена грамотрицательная анаэробная флора. После воздействия ультразвука внутриканально и биостимулирующего света «Bioptron» чрезкожно обеспечило получение отрицательных результатов посевов, которые сохраняли свою стабильность в течение 14 суток при экспозиции посевов в условиях термостата при температуре $37^{0} \mathrm{C}$ (табл. 6).

В результате клинической апробации использования растворов велтосепта различной концентрации $(0,2 ; 0,1 ; 0,05 \%)$ как изолированно $(0,2 \%)$, так и в комплексной терапии для санации корневых каналов зубов, было установлено, что абсолютно бесспорным, достоверным, экспериментально доказанным и подтвержденным на клиническом материале является применение для дезинфекции каналов зубов 0,2\% раствора велтосепта в комплексе с ультразвуком и светом «Bioptron».

Таблица 6

Антимикробная эффективность комплексного воздействия химических и физических агентов для санации корневых каналов зубов и купирования воспалительных явлений в периодонте

\begin{tabular}{|c|c|c|c|c|c|}
\hline $\begin{array}{l}\text { № } \\
\Pi\end{array}$ & \multicolumn{5}{|c|}{$\begin{array}{l}\text { Результаты посевов содержимого корневых каналов у больных после обработки } \\
\text { каналов: }\end{array}$} \\
\hline $\mathrm{p}$ & 1-й группы & $2-\breve{И} \quad \Gamma$ & уппы & & 3-й группы \\
\hline o & $0,2 \%$ PBC & $0,1 \%$ PBC & $\begin{array}{l}0,1 \% \mathrm{PBC} \\
+\mathrm{y} 3\end{array}$ & $0,05 \%$ PBC & $\begin{array}{l}0,05 \% \text { РВС + УЗ внутриканально } \\
+ \text { «Биоптрон» чрезкожно }\end{array}$ \\
\hline 1 & - & - & - & + & - \\
\hline 2 & - & + & - & + & - \\
\hline 3 & - & - & - & + & - \\
\hline 4 & - & + & - & - & - \\
\hline 5 & - & - & - & + & - \\
\hline 6 & - & - & - & - & - \\
\hline 7 & - & + & - & + & - \\
\hline 8 & - & - & - & - & - \\
\hline 9 & - & + & - & + & - \\
\hline $\begin{array}{l}1 \\
0\end{array}$ & - & + & - & + & - \\
\hline
\end{tabular}

Обозначения: «-» - отсутствие роста микрофлоры «+» - наличие роста микрофлоры 
Санация корневых каналов велтосептом усиливается: с ультразвуком в концентрации $0,1 \%$, с ультразвуком и биостимулирующим светом «Bioptron», активность препарата достигнута в 0,05\% концентрации.

\section{ГЛАВА 4. РЕЗУЛЬТАТЫ ЛЕЧЕНИЯ ОСТРЫХ И ОБОСТРИВШИХСЯ ХРОНИЧЕСКИХ ВЕРХУШЕЧНЫХ ПЕРИОДОНТИТОВ ПОД ВОЗДЕЙСТВИЕМ РАЗЛИЧНЫХ ЛЕЧЕБНЫХ КОМПЛЕКСОВ С ПРИМЕНЕНИЕМ ПОЛЯРИЗОВАННОГО СВЕТА «ВIOРТRОN»}

Для оценки эффективности проведенной терапии различными комплексами с применением УЗ и света «Bioptron» и без них сопоставлялись субъективные, объективные и рентгенологические данные по индексу PAI до и после лечения всех форм ОВП и ОХВП.

4.1.1. Клиническая характеристика и рентгенологические данные больных с острыми верхушечными периодонтитами в стадии интоксикации (ОВПСИ) до лечения (первая группа)

В группе ОВПСИ обследовано 50 пациентов, которые были разделены на пять подгрупп в зависимости от применяемого комплекса лечебных воздействий. У всех пациентов данной группы была установлена сходная клиническая картина (табл. 7, 8).

Таблица 7

Субъективные клинические проявления у больных с острыми верхушечными периодонтитами в стадии интоксикации до лечения

(первая группа)

\begin{tabular}{|c|c|c|c|c|c|c|c|}
\hline \multirow{2}{*}{$\begin{array}{l}\text { Под- } \\
\text { группа }\end{array}$} & \multirow{2}{*}{$\begin{array}{l}\text { Кол-во } \\
\text { больных } \\
\text { /зубов }\end{array}$} & & \multicolumn{5}{|c|}{ Субъективные данные } \\
\hline & & & $\begin{array}{l}\text { Боль причин } \\
\text { ного зуба, } \\
\text { ноющая, } \\
\text { постоянная }\end{array}$ & $\begin{array}{l}\text { Симптом } \\
\text { выросшего } \\
\text { зуба }\end{array}$ & $\begin{array}{c}\text { Головная } \\
\text { боль }\end{array}$ & $\begin{array}{l}\text { Повышение } \\
\text { температуры } \\
\text { тела до } 38^{0} \mathrm{C}\end{array}$ & $\begin{array}{c}\text { Потеря } \\
\text { трудо- } \\
\text { способ- } \\
\text { ности }\end{array}$ \\
\hline \multirow[t]{2}{*}{1} & \multirow[t]{2}{*}{$10 / 10$} & абс. & 10 & 8 & 5 & 0 & 0 \\
\hline & & $\%$ & 100 & 80,00 & 50,00 & 0,00 & 0,00 \\
\hline \multirow[t]{2}{*}{2} & \multirow[t]{2}{*}{$10 / 10$} & абс. & 10 & 8 & 6 & 0 & 0 \\
\hline & & $\%$ & 100 & 80,00 & 60,00 & 0,00 & 0,00 \\
\hline \multirow[t]{2}{*}{3} & \multirow[t]{2}{*}{$10 / 10$} & абс. & 10 & 8 & 6 & 0 & 0 \\
\hline & & $\%$ & 100 & 80,00 & 60,00 & 0,00 & 0,00 \\
\hline \multirow[t]{2}{*}{4} & \multirow[t]{2}{*}{$10 / 10$} & абс. & 10 & 9 & 5 & 0 & 0 \\
\hline & & $\%$ & 100 & 90,00 & 50,00 & 0,00 & 0,00 \\
\hline \multirow[t]{2}{*}{5} & \multirow[t]{2}{*}{$10 / 10$} & абс. & 10 & 9 & 5 & 0 & 0 \\
\hline & & $\%$ & 100 & 90,00 & 50,00 & 0,00 & 0,00 \\
\hline Итого & $50 / 50$ & & & & & & \\
\hline
\end{tabular}


Таблица 8

Объективные клинические проявления у больных с острыми формами верхушечных периодонтитов в стадии интоксикации до лечения

(первая группа)

\begin{tabular}{|c|c|c|c|c|c|c|c|c|}
\hline \multirow{2}{*}{$\begin{array}{l}\text { Под } \\
\text { груп- } \\
\text { па }\end{array}$} & \multirow{2}{*}{$\begin{array}{l}\text { Кол-во } \\
\text { боль- } \\
\text { ных } \\
\text { /зубов }\end{array}$} & & \multicolumn{5}{|c|}{ Объективные клинические проявления } & \multirow[b]{2}{*}{$\begin{array}{c}\text { Пери- } \\
\text { апикаль } \\
\text {-ный } \\
\text { индек } \\
\text { с PAI, } \\
\text { баллы }\end{array}$} \\
\hline & & & $\begin{array}{c}\text { Асим- } \\
\text { мет- } \\
\text { рия } \\
\text { лица }\end{array}$ & $\begin{array}{l}\text { Увеличение } \\
\text { болезнен- } \\
\text { ности } \\
\text { лимфоузлов }\end{array}$ & $\begin{array}{l}\text { Гиперемия и } \\
\text { отечность } \\
\text { десны } \\
\text { причинного } \\
\text { зуба }\end{array}$ & $\begin{array}{l}\text { Перкутор- } \\
\text { ная } \\
\text { реакция } \\
\text { при- } \\
\text { чинного } \\
\text { зуба }\end{array}$ & $\begin{array}{l}\text { Нали- } \\
\text { чие } \\
\text { экссу- } \\
\text { дата в } \\
\text { канала } \\
\text { x }\end{array}$ & \\
\hline \multirow[t]{2}{*}{1} & \multirow[t]{2}{*}{$10 / 10$} & aбc. & 0 & 10 & 8 & 10 & 10 & 1 \\
\hline & & $\%$ & 0,00 & 100 & 80,00 & 100 & 100 & \\
\hline \multirow[t]{2}{*}{2} & \multirow[t]{2}{*}{$10 / 10$} & абс. & 0 & 8 & 7 & 10 & 10 & 1 \\
\hline & & $\%$ & 0,00 & 80,00 & 70,00 & 100 & 100 & \\
\hline \multirow[t]{2}{*}{3} & \multirow[t]{2}{*}{$10 / 10$} & абс. & 0 & 9 & 8 & 10 & 10 & 1 \\
\hline & & $\%$ & 0,00 & 90,00 & 80,00 & 100 & 100 & \\
\hline \multirow[t]{2}{*}{4} & \multirow[t]{2}{*}{$10 / 10$} & абс. & 0 & 9 & 9 & 10 & 10 & 1 \\
\hline & & $\%$ & 0,00 & 90,00 & 90,00 & 100 & 100 & \\
\hline \multirow[t]{2}{*}{5} & \multirow[t]{2}{*}{$10 / 10$} & aбc. & 0 & 10 & 9 & 10 & 10 & 1 \\
\hline & & $\%$ & 0,00 & 100 & 90,00 & 100 & 100 & \\
\hline
\end{tabular}

Анализируя данные таблиц 7 и 8 у больных с острыми верхушечными периодонтитами в стадии интоксикации (ОВПСИ) первой подгруппы, состоящей из 10 пациентов, в которой обследовано 10 зубов (по одному у каждого пациента), были установлены жалобы у всех пациентов на постоянную ноющую, усиливающуюся боль в области причинного зуба, боль при накусывании на зуб (симптом выросшего зуба). Головная боль и недомогание беспокоили пять пациентов.

Объективно установлено у всех увеличение и болезненность регионарных лимфоузлов, гиперемия и отечность десны в области причинного зуба, болезненная перкуторная реакция причинного зуба, в $50,00 \%$ - соседних зубов. Рентгенологических изменений в периодонте не выявлено.

Во второй подгруппе у больных ОВПСИ было обследовано так же 10 пациентов, которые жаловались на постоянную локальную боль в области причинного зуба. Симптом «выросшего зуба» отмечали 8 пациентов, шесть из них предъявляли жалобы на головную боль. У всех пациентов установлена болезненная перкуторная реакция причинного зуба, у 60,00\% - соседних 
зубов; у восьми из них были увеличены и болезненны лимфоузлы и гиперемированная слизистая оболочка причинного зуба у семи из них. Рентгенологических изменений в костных тканях не выявлено.

В третьей подгруппе у больных $\mathrm{c}$ острыми верхушечными периодонтитами в стадии интоксикации наблюдались 10 пациентов, которые предъявляли жалобы на постоянную ноющую нарастающую боль причинного зуба, боль при накусывании, восемь из них отмечали «симптом выросшего зуба».

При осмотре установлено у десяти больных увеличение и болезненность регионарных лимфоузлов, явления гиперемии слизистой оболочки в области больного зуба определялись у восьми из них. Болезненная перкуторная вертикальная реакция причинного зуба зарегистрирована у всех 10 обследованных зубов. Рентгенологических изменений в периодонте не выявлено.

В четвертой подгруппе у пациентов с ОВПСИ обследовано 10 зубов и установлены жалобы на постоянную ноющую боль, боль при накусывании на причинный зуб, симптом «выросшего зуба» отмечали девять пациентов из 10, пять из них предъявляли жалобы на головную боль. При объективном исследовании у девяти пациентов зарегистрировано увеличение и болезненность регионарных лимфатических узлов и гиперемия слизистой оболочки в области причинного зуба, а также у всех 10 больных болезненная перкуторная реакция больного зуба и 60,00\% - соседних зубов. При рентгенологическом обследовании изменений в периапикальной области не выявлено.

В пятой подгруппе первой группы с ОВПСИ обследовано также 10 пациентов. На постоянную ноющую боль в области причинного зуба предъявляли все 10 больных, девять из них жаловались на «симптом выросшего зуба» и боль при накусывании, у пяти из них выявлена головная боль. При осмотре установлено увеличение и болезненность регионарных лимфатических желез и болезненная перкуторная реакция у всех 10 больных. 
Гиперемия и отек слизистой оболочки причинного зуба установлена у девяти больных.

У всех 50 пациентов с острыми верхушечными периодонтитами в стадии интоксикации определялся экссудат в корневых каналах. На рентгенограммах отсутствовали деструктивные изменения в апикальном периодонте, что указывало на краткосрочность развития процесса (1-2 недели), что соответствует по периапикальному индексу PAI-1 баллу.

\subsection{2. Ближайшие результаты лечения острых верхушечных периодонтитов в стадии интоксикации различными лечебными комплексами (первая группа)}

Подготовка корневых каналов включала анестезию, определение рабочей длины корневого канала апекслокатором, механическую обработку по методу Crown-down и применение различных комплексов лечебных воздействий, изучаемых в работе. Критерием успешной терапии в ближайшие сроки после комплекса лечебных воздействий на периодонт послужили: отсутствие жалоб, участие причинного зуба в акте жевания, заполнение корневых каналов различными пломбировочными материалами до верхушечного отверстия методом латеральной конденсации материала бета-гуттаперчевым штифтом. Ближайшие результаты купирования (3-5 дней) острых явлений в периодонте отражены в таблице 9.

Анализ данных таблицы 9 показал, что у пациентов с ОВПСИ, у которых при санации корневых каналов зубов использовали $0,2 \%$ раствор хлоргексидина (первая подгруппа), боль в области причинного зуба была купирована в пяти $(50,00 \%)$ случаях, перкуторная реакция причинного зуба была безболезненной у четырех $(40,00 \%)$ больных. Установлена также безболезненная перкуссия соседних зубов в 100\% случаев. Гиперемия и отечность десны исчезла у четырех пациентов из восьми до лечения.

Во второй подгруппе, где в качестве дезинфектанта корневых каналов зубов при ОВПСИ применялся $0,2 \%$ раствор велтосепта боли прекратились в $80,00 \%$ случаев. Гиперемия и отечность десны исчезли у 50,00\% больных. 
Безболезненная перкуссия причинного зуба установлена у 80,00\% пациентов, соседних зубов - в 100\% случаев. В течение 3-5 дней прекратилась экссудация из корневых каналов у всех пациентов.

Таблица 9

Динамика клинических признаков острого воспаления в периапикальных тканях под воздействием различных лечебных комплексов у больных с ОВПСИ (первая группа)

\begin{tabular}{|c|c|c|c|c|c|c|c|c|c|c|c|c|c|}
\hline \multirow{3}{*}{\multicolumn{2}{|c|}{\begin{tabular}{c|l} 
П & Лечеб-ный \\
о & комп-лекс
\end{tabular}}} & \multicolumn{12}{|c|}{ Купирование симптомов острого воспаления } \\
\hline & & \multicolumn{3}{|c|}{$\begin{array}{c}\text { Прекращение } \\
\text { боли }\end{array}$} & \multicolumn{3}{|c|}{$\begin{array}{c}\text { Исчезновение } \\
\text { гиперемии и } \\
\text { отечности десны }\end{array}$} & \multicolumn{3}{|c|}{$\begin{array}{c}\text { Болезненная } \\
\text { перкуссия } \\
\text { причинного зуба }\end{array}$} & \multicolumn{3}{|c|}{$\begin{array}{c}\text { Прекращение } \\
\text { явлений } \\
\text { экссудации }\end{array}$} \\
\hline & & до & \multicolumn{2}{|c|}{ после } & \multirow[t]{2}{*}{ до } & \multicolumn{2}{|c|}{ после } & \multirow[t]{2}{*}{ до } & \multicolumn{2}{|c|}{ после } & \multirow[t]{2}{*}{ до } & \multicolumn{2}{|c|}{ после } \\
\hline$y$ & & & aбc & $\%$ & & абс & $\%$ & & абс & $\%$ & & aбc & $\%$ \\
\hline 1 & $0,2 \% \mathrm{PX} \Gamma$ & 10 & 5 & 50,00 & 8 & 4 & 50,00 & 10 & 4 & 40,00 & 10 & 10 & 100 \\
\hline 2 & $0,2 \% \mathrm{PBC}$ & 10 & 8 & $\begin{array}{l}80,00 \\
p>0,05\end{array}$ & 7 & 3 & $\begin{array}{c}50,00 \\
p>0,05\end{array}$ & 10 & 8 & $\begin{array}{c}80,00 \\
p>0,05\end{array}$ & 10 & 10 & 100 \\
\hline 3 & $\begin{array}{l}0,2 \% \\
\mathrm{PBC}+\mathrm{y3}\end{array}$ & 10 & 8 & $\begin{array}{l}80,00 \\
p>0,05\end{array}$ & 8 & 4 & $\begin{array}{c}50,00 \\
p>0,05\end{array}$ & 10 & 8 & $\begin{array}{c}80,00 \\
p>0,05\end{array}$ & 10 & 10 & 100 \\
\hline 4 & $\begin{array}{l}0,2 \% \text { PBC+ } \\
\text { БТ }+ \text { У3 }\end{array}$ & 10 & 10 & $\begin{array}{l}100 \\
p<0,01\end{array}$ & 9 & 9 & $\begin{array}{c}100 \\
p<0,02\end{array}$ & 10 & 10 & $\begin{array}{c}100 \\
p<0,01\end{array}$ & 10 & 10 & 100 \\
\hline 5 & $\begin{array}{l}0,2 \% \mathrm{PBC} \\
+\mathrm{Y} 3+\mathrm{БT}\end{array}$ & 10 & 10 & $\begin{array}{l}100 \\
p<0,01\end{array}$ & 9 & 9 & $\begin{array}{c}100 \\
p<0,02\end{array}$ & 10 & 10 & $\begin{array}{c}100 \\
p<0,01\end{array}$ & 10 & 10 & 100 \\
\hline
\end{tabular}

Примечание: $\mathrm{p}$ - достоверность различий по отношению к 1 подгруппе.

В третьей подгруппе корневые каналы зубов при ОВПСИ обрабатывались $0,2 \%$ раствором велтосепта в сочетании с ультразвуком внутриканально. Под воздействием данного комплекса купирование явлений острого воспаления периапикальных тканей установлено у восьми пациентов $(80,00 \%) ;$ у четырех $(50,00 \%)$ из них исчезли явления гиперемии и отечности тканей десны, прекратилась экссудация из корневых каналов, безболезненная перкуторная реакция причинного зуба установлена у восьми пациентов из десяти, соседних зубов - в 100\% случаев.

В четвертой и пятой подгруппах санация корневых каналов зубов при ОВПСИ осуществлялась озвученным 0,2\% раствором велтосепта, а также больным данных подгрупп был применен двумя полями чрезкожно поляризованный свет «Bioptron», обладающий мощным 
противовоспалительным действием. В результате воспалительные явления в периодонте были купированы в течение трех дней в $100 \%$ случаев: прекратились боли после одного сеанса света «Bioptron», исчезли гиперемия, отечность десны, экссудация из корневых каналов, установлена безболезненная перкуссия как причинного, так и соседних зубов у всех больных в течение трех дней.

Таким образом, сравнивая показатели купирования острых явлений в периодонте при ОВПСИ в ближайшие сроки наблюдений (3-5 дней), можно с уверенностью констатировать, что наиболее высокие результаты достигнуты в четвертой и пятой подгруппах, где в комплексе лечебных воздействий была применена биостимулирующая терапия светом «Bioptron».

\subsection{3. Сравнительная оценка эффективности использования} различных пломбировочных материалов при лечении острых периодонтитов в стадии интоксикации (ОВПСИ)

Для сравнительной оценки эффективности использования различных пломбировочных материалов для заполнения корневых каналов, проводился анализ ближайших осложнений, связанных с пломбированием зубов (таблица 10 и 11$)$.

Интерпретация данных таблиц 10 и 11 показала, что осложнения в ближайшие сроки после лечения у больных с ОВПСИ наблюдались в зависимости от комплекса лечебных воздействий. Так, в первой подгруппе, где каналы пломбировались ЭВ и обрабатывались 0,2\% РХГ, наблюдался наибольший процент осложнений (80,00\% случаев), которые выражались в появлении боли при накусывании и болевой реакции периодонта на вертикальную перкуссию, а так же гиперемии и отечности десны в области причинного зуба, сглаженности переходной складки (50,00\%).

Во второй подгруппе, где корневые каналы зубов обрабатывались $0,2 \%$ раствором велтосепта и заполнялись велтосепт-пастой № 1 ТР, осложнения возникли у четырех пациентов $(40,00 \%)$ в виде боли при накусывании и болезненной перкуторной реакции причинного зуба, гиперемии и отечности 
десны, у одного из них возникла сглаженность переходной складки в области причинного зуба.

Таблица 10

\section{Лечебные комплексы воздействия у пациентов с ОВПСИ (первая группа)}

\begin{tabular}{|c|c|c|c|c|}
\hline \multirow{2}{*}{$\begin{array}{l}\text { Подгр } \\
\text { уппа }\end{array}$} & $\begin{array}{l}\text { Кол-во } \\
\text { зубов }\end{array}$ & \multicolumn{3}{|c|}{ Комплекс лечебных воздействий } \\
\cline { 3 - 5 } & & Медикаментозное & Физическое & $\begin{array}{c}\text { Пломбировочный } \\
\text { материал }\end{array}$ \\
\hline 1 & 10 & $0,2 \%$ РХГ & - & ЭВ \\
\hline 2 & 10 & $0,2 \%$ РВС & - & ВСП № 1 \\
\hline 3 & 10 & $0,2 \%$ РВС & У3 & ВСП № 1+ГШ \\
\hline 4 & 10 & $0,2 \%$ РВС & БТ+У3 & ВСПОИ № 2+ГШ \\
\hline 5 & 10 & $0,2 \%$ РВС & У3+БТ & ОТ-«Кальсепт»+ВСПОИ № 2+ГШ \\
\hline
\end{tabular}

В третьей подгруппе лечебный комплекс состоял из медикаментозной обработки системы макро- и микроканалов 0,2\% раствором велтосепта и ультразвуком, каналы зубов пломбировались велтосепт-пастой №1 ТР. После воздействия данным лечебным комплексом осложнения в виде боли при накусывании на причинный зуб возникли у двух (20,00\%) больных, у которых установлена болевая реакция запломбированного зуба при перкуссии и накусывании, гиперемия и отечность слизистой оболочки десны.

Таблица 11

Клинические данные после пломбирования корневых каналов у пациентов с ОВПСИ различными эндодонтическими материалами (первая группа)

\begin{tabular}{|c|c|c|c|c|c|c|c|c|c|}
\hline \multirow{3}{*}{$\begin{array}{l}\text { Подг } \\
\text { руппа }\end{array}$} & \multirow{3}{*}{$\begin{array}{l}\text { Кол- } \\
\text { во } \\
\text { зубов }\end{array}$} & \multirow{2}{*}{\multicolumn{2}{|c|}{$\begin{array}{c}\text { Осложнения } \\
\text { после } \\
\text { пломбирования }\end{array}$}} & \multicolumn{6}{|c|}{ Клинические симптомы } \\
\hline & & & & \multicolumn{2}{|c|}{$\begin{array}{c}\text { Боль при } \\
\text { перкуссии и } \\
\text { накусывании на } \\
\text { причинный зуб }\end{array}$} & \multicolumn{2}{|c|}{$\begin{array}{c}\text { Гиперемия, } \\
\text { отек мягких } \\
\text { тканей }\end{array}$} & \multicolumn{2}{|c|}{$\begin{array}{c}\text { Сглаженность } \\
\text { переходной } \\
\text { складки }\end{array}$} \\
\hline & & абс & $\%$ & абс & $\%$ & абс & $\%$ & абс & $\%$ \\
\hline 1 & 10 & 8 & 80,00 & 8 & 80,00 & 8 & 80,00 & 5 & 50,00 \\
\hline 2 & 10 & 4 & $\begin{array}{c}40,00 \\
p>0,05\end{array}$ & 4 & $\begin{array}{c}40,00 \\
p>0,05\end{array}$ & 4 & $\begin{array}{c}40,00 \\
p>0,05\end{array}$ & 1 & $\begin{array}{c}10,00 \\
p>0,05\end{array}$ \\
\hline 3 & 10 & 2 & $\begin{array}{c}20,00 \\
\mathrm{p}<0,01\end{array}$ & 2 & $\begin{array}{c}20,00 \\
\mathrm{p}<0,01\end{array}$ & 2 & $\begin{array}{c}20,00 \\
\mathrm{p}<0,01\end{array}$ & 0 & $\begin{array}{c}0,00 \\
p<0,01\end{array}$ \\
\hline 4 & 10 & 0 & $\begin{array}{c}0,00 \\
\mathrm{p}<0,01\end{array}$ & 0 & $\begin{array}{c}0,00 \\
\mathrm{p}<0,01\end{array}$ & 0 & $\begin{array}{c}0,00 \\
\mathrm{p}<0,01\end{array}$ & 0 & $\begin{array}{c}0,00 \\
\mathrm{p}<0,01\end{array}$ \\
\hline 5 & 10 & 0 & $\begin{array}{c}0,00 \\
p<0,01\end{array}$ & 0 & $\begin{array}{c}0,00 \\
\mathrm{p}<0,01\end{array}$ & 0 & $\begin{array}{c}0,00 \\
p<0,01\end{array}$ & 0 & $\begin{array}{c}0,00 \\
p<0,01\end{array}$ \\
\hline
\end{tabular}

Примечание: $\mathrm{p}$ - достоверность различий по отношению к 1 подгруппе. 
В четвертой подгруппе санация корневой системы каналов осуществлялась озвученным $0,2 \%$ раствором велтосепта, каналы пломбировались велтосепт-пастой № 2 с гидроксиапатитом «Остеоиндуцин» ТР, но до и после пломбирования корневых каналов был применен поляризованный свет «Bioptron». В результате никаких осложнений у пациентов данной подгруппы после лечения не возникло.

В пятой подгруппе применялся отсроченный метод. Лечебный комплекс состоял из воздействия на микрофлору макро- и микроканалов озвученным 0,2\% раствором велтосепта, временной обтурации корневых каналов материалом «Кальсепт», пломбирование каналов осуществлялось велтосептпастой № 2 с нанодисперсным гидроксиапатитом «Остеоиндуцин». Для предупреждения возникновения обострения воспалительного процесса применялся до и после биостимулирующий свет «Bioptron». Один сеанс до и после пломбирования корневых каналов света «Bioptron» предупредил осложнения и в результате ни у одного пациента не возникло жалоб после пломбирования корневых каналов зубов при ОВПСИ.

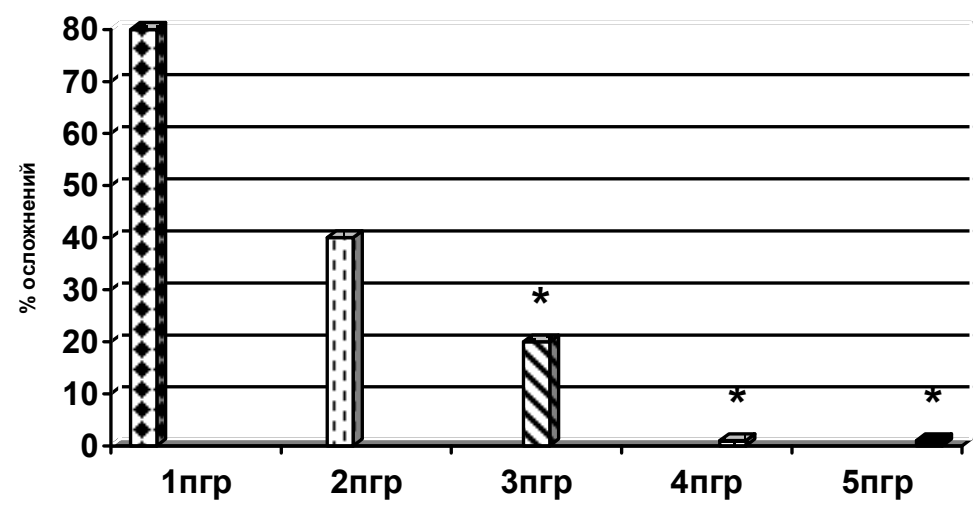

由 $0,2 \% \mathrm{PХГ}+Э \mathrm{~B}$

๑ $0,2 \%$ РBC+BCП№1

$\mathbf{\nabla} 0,2 \% \mathrm{PBC}+\mathrm{У} 3+\mathrm{BC}$ №1+ГШ

田 $0,2 \%$ РВС+БТ+ВСПОИ№2+ГШ

0,2\%РВС+УЗ+БТ+ВСПОИ№2+ ГШ

Примечание: * $<0,01$ по отношению к 1-ой подгруппе

Рис.8. Сравнительная характеристика осложнений после лечения ОВП различными лечебными комплексами (первая группа)

Таким образом, в ближайшие сроки наблюдения (3-5 дней) наиболее высокие результаты достигнуты в четвертой и пятой подгруппах, где применялась биостимулирующая терапия светом «Bioptron» в сочетании с 
обработкой системы макро- и микроканалов озвученным 0,2\% PBC и пломбирование каналов велтосепт-пастой № 2 c нанодисперсным гидроксиапатитом «Остеоиндуцин». Анализ данных пломбирования корневых каналов при острых периодонтитах в стадии интоксикации ВСПОИ № 2 свидетельствует о положительном влиянии ее на патологический очаг воспаления в периодонте в ближайшие сроки наблюдения (рис. 8).

\subsection{1. Клиническая характеристика и рентгенологические данные у больных с острыми периодонтитами в стадии экссудации (ОВПСЭ) до лечения (вторая группа)}

Во вторую группу подобраны 50 пациентов с острыми верхушечными периодонтитами в стадии экссудации, которые были разделены на пять подгрупп (в зависимости от комплекса лечебных воздействий).

Таблица 12

Субъективные клинические проявления у больных с ОВПСЭ до лечения (вторая группа)

\begin{tabular}{|c|c|c|c|c|c|c|c|}
\hline \multirow{2}{*}{$\begin{array}{l}\text { Под- } \\
\text { груп- } \\
\text { па }\end{array}$} & \multirow{2}{*}{$\begin{array}{l}\text { Кол-во } \\
\text { боль- } \\
\text { ных } \\
\text { /зубов }\end{array}$} & & \multicolumn{5}{|c|}{ Субъективные данные } \\
\hline & & & $\begin{array}{l}\text { Боль при- } \\
\text { чинного } \\
\text { зуба, } \\
\text { ноющая, } \\
\text { постоянная }\end{array}$ & $\begin{array}{l}\text { Симптом } \\
\text { выросшего } \\
\text { зуба }\end{array}$ & $\begin{array}{c}\text { Головная } \\
\text { боль }\end{array}$ & $\begin{array}{c}\text { Повышение } \\
\text { температуры } \\
\text { тела до } 39^{0} \mathrm{C}\end{array}$ & $\begin{array}{c}\text { Потеря } \\
\text { трудоспо } \\
\text { собности }\end{array}$ \\
\hline \multirow[t]{2}{*}{6} & \multirow[t]{2}{*}{$10 / 10$} & абс. & 10 & 10 & 8 & 8 & 8 \\
\hline & & $\%$ & 100 & 100 & 80,00 & 80,00 & 80,00 \\
\hline \multirow[t]{2}{*}{7} & \multirow[t]{2}{*}{$10 / 10$} & aбc. & 10 & 10 & 9 & 8 & 8 \\
\hline & & $\%$ & 100 & 100 & 90,00 & 80,00 & 80,00 \\
\hline \multirow[t]{2}{*}{8} & \multirow[t]{2}{*}{$10 / 10$} & aбc. & 10 & 10 & 8 & 8 & 8 \\
\hline & & $\%$ & 100 & 100 & 80,00 & 80,00 & 80,00 \\
\hline \multirow[t]{2}{*}{9} & \multirow[t]{2}{*}{$10 / 10$} & aбc. & 10 & 10 & 5 & 8 & 8 \\
\hline & & $\%$ & 100 & 100 & 50,00 & 80,00 & 80,00 \\
\hline \multirow[t]{2}{*}{10} & \multirow[t]{2}{*}{$10 / 10$} & aбc. & 10 & 10 & 5 & 9 & 9 \\
\hline & & $\%$ & 100 & 100 & 50,00 & 90,00 & 90,00 \\
\hline Итого & $50 / 50$ & & & & & & \\
\hline
\end{tabular}

В данной группе больных клиническое состояние утяжеляется за счет невозможности оттока экссудата (зуб пломбирован, покрыт коронкой, канал заполнен распадом) и свищевого хода нет. Дотрагивание до зуба и пальпация по переходной складке болезненны, слизистая оболочка гиперемирована и отечна, часто при возникновении абсцесса в периапикальной области 
происходит распространение гнойного экссудата в окружающие ткани, резорбция кости, интоксикация организма с повышением температуры тела до $38-38,5^{0} \mathrm{C}$ (таблицы 12, 13). В шестой подгруппе все 10 пациентов жаловались на постоянные ноющие боли в области причинного зуба, «симптом выросшего зуба», восемь из них предъявляли жалобы на головную боль, повышение температуры тела до $38-39^{0} \mathrm{C}$ и потерю трудоспособности. У всех 10 пациентов установлено увеличение и болезненность лимфатических желез, гиперемия и отек переходной складки, резкую болезненность при перкуссии, наличие экссудата в каналах. У 5 из них зарегистрирован коллатеральный отек мягких тканей лица.

Таблица 13

Объективные клинические проявления у больных с ОВПСЭ до лечения (вторая группа)

\begin{tabular}{|c|c|c|c|c|c|c|c|c|}
\hline \multirow[b]{2}{*}{ 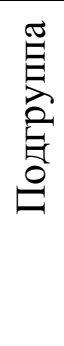 } & \multirow{2}{*}{$\begin{array}{l}\text { Кол-во } \\
\text { боль- } \\
\text { ных } \\
\text { /зубов }\end{array}$} & & \multicolumn{5}{|c|}{ Объективные клинические проявления } & \multirow[b]{2}{*}{$\begin{array}{l}\text { Периапи- } \\
\text { кальный } \\
\text { индекс } \\
\text { PAI, } \\
\text { баллы }\end{array}$} \\
\hline & & & $\begin{array}{l}\text { Асиммет- } \\
\text { рия лица }\end{array}$ & $\begin{array}{l}\text { Увеличение } \\
\text { болезнен- } \\
\text { ности } \\
\text { лимфоузлов }\end{array}$ & $\begin{array}{l}\text { Гиперемия } \\
\text { и } \\
\text { отечность } \\
\text { десны } \\
\text { причин- } \\
\text { ного зуба }\end{array}$ & $\begin{array}{c}\text { Перкуторная } \\
\text { реакция } \\
\text { причинного } \\
\text { зуба }\end{array}$ & $\begin{array}{c}\text { Наличие } \\
\text { экссудата } \\
\text { в каналах }\end{array}$ & \\
\hline \multirow[t]{2}{*}{6} & $10 /$ & абс. & 5 & 10 & 10 & 10 & 10 & \multirow[t]{2}{*}{2} \\
\hline & 10 & $\%$ & 50,00 & 100 & 100 & 100 & 100 & \\
\hline \multirow[t]{2}{*}{7} & $10 /$ & aбc. & 6 & 10 & 10 & 10 & 10 & \multirow[t]{2}{*}{2} \\
\hline & 10 & $\%$ & 60,00 & 100 & 100 & 100 & 100 & \\
\hline \multirow[t]{2}{*}{8} & $10 /$ & абс. & 6 & 10 & 10 & 10 & 10 & \multirow[t]{2}{*}{2} \\
\hline & 10 & $\%$ & 60,00 & 100 & 100 & 100 & 100 & \\
\hline \multirow[t]{2}{*}{9} & $10 /$ & абс. & 7 & 10 & 10 & 10 & 10 & \multirow[t]{2}{*}{2} \\
\hline & 10 & $\%$ & 70,00 & 100 & 100 & 100 & 100 & \\
\hline \multirow[t]{2}{*}{10} & $10 /$ & абс. & 6 & 10 & 10 & 10 & 10 & \multirow[t]{2}{*}{2} \\
\hline & 10 & $\%$ & 60,00 & 100 & 100 & 100 & 100 & \\
\hline
\end{tabular}

Сходная клиническая картина была у больных седьмой подгруппы с острыми явлениями в периодонте. Все 10 больных также жаловались на постоянную ноющую боль причинного зуба, девять из них жаловались на головную боль, у 8 был подъем температуры тела до $38,5^{0} \mathrm{C}$ с потерей трудоспособности. Объективно установлена асимметрия лица у 6 человек, увеличение регионарных лимфатических желез, резкая перкуторная реакция 
у всех 10 больных, у 8 из них установлена болезненная перкуссия соседних зубов.

В восьмой подгруппе все 10 пациентов предъявляли жалобы на постоянную ноющую боль, боль при накусывании на причинный зуб, 8 из них жаловались на головную боль, повышение температуры тела и потерю трудоспособности. При осмотре обнаружен коллатеральный отек мягких тканей лица у 6 пациентов и увеличение, болезненность лимфоузлов, у всех пациентов отмечалась гиперемия и отек десны, резкая перкуторная реакция причинного зуба, у 8 из них на перкуссию реагировали болью соседние зубы.

В девятой группе все больные (10 человек) жаловались на головную боль, недомогание, резкую боль при накусывании на причинный зуб, у 8 из них было повышение температуры тела с потерей трудоспособности. Объективно установлено у всех 10 пациентов увеличение регионарных лимфоузлов, гиперемия и отечность по переходной складке в области причинного зуба, их резкую болевую реакцию на перкуссию и у 8 из них установлена положительная перкуссия соседних зубов, у семи из них развился коллатеральный отек мягких тканей лица.

В десятую подгруппу с острыми экссудативными явлениями в периодонте отобрано 10 пациентов, которые предъявляли жалобы на постоянную ноющую боль причинного зуба, на головную боль, повышение температуры тела и потерю трудоспособности жаловались 9 из них. Объективно установлена у всех больных резкая перкуторная реакция как причинного, так и соседних зубов, гиперемия и отечность десны, увеличение регионарных лимфоузлов, у 6 из них была асимметрия лица за счет припухлости в области причинного зуба. У всех 50 больных с острыми явлениями в периодонте в стадии экссудации был экссудат в корневых каналах. Рентгенологически в костной ткани у верхушки корня отмечались незначительные деструктивные изменения в виде смазанности костного рисунка, нечеткости рисунка кортикальной пластинки у верхушки корня и неравномерного расширения периодонтальной щели с четкими контурами, 
которые зависели от воспалительного процесса и были не типичны для апикального периодонтита. По индексу PAI данные изменения костных структур трактуются как 2 балла.

4.2.2. Ближайшие результаты лечения острых периодонтитов в фазе экссудации с использованием ирриганта велтосепта, ультразвука (внутриканально) и света «Bioptron» и без них

В настоящей главе представлены результаты использования медикаментозных средств для обработки корневых каналов в сочетании с физическими факторами и сроки купирования воспалительного процесса в периодонте. Критериями успешной терапии служили: отсутствие жалоб и прекращение экссудации из корневых каналов в ближайшие сроки (3-5 дней). Динамика клинических признаков острого воспаления в периапикальных тканях под воздействием различных лечебных комплексов представлена в таблице 14 и 15.

Таблица 14

Динамика клинических признаков острого воспаления в периапикальных тканях под воздействием различных лечебных комплексов у больных с ОВПСЭ (вторая группа)

\begin{tabular}{|c|c|c|c|c|c|c|c|c|c|c|}
\hline \multirow{4}{*}{ 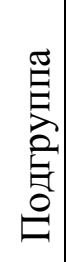 } & \multirow{4}{*}{$\begin{array}{l}\text { Комплекс } \\
\text { лечебных } \\
\text { воздействий }\end{array}$} & \multicolumn{9}{|c|}{ Купирование симптомов острого воспаления } \\
\hline & & \multicolumn{3}{|c|}{ Прекращение боли } & \multicolumn{3}{|c|}{$\begin{array}{c}\text { Уменьшение } \\
\text { асимметрии лица }\end{array}$} & \multicolumn{3}{|c|}{$\begin{array}{c}\text { Исчезновение гиперемии } \\
\text { и отечности десны }\end{array}$} \\
\hline & & \multirow[t]{2}{*}{ до } & \multicolumn{2}{|c|}{ После } & \multirow[t]{2}{*}{ до } & \multicolumn{2}{|c|}{ после } & \multirow[t]{2}{*}{ до } & \multicolumn{2}{|c|}{ после } \\
\hline & & & абс. & $\%$ & & абс. & $\%$ & & абс. & $\%$ \\
\hline 6 & $0,2 \% \mathrm{PX} \Gamma$ & 10 & 4 & 40,00 & 5 & 2 & 25,00 & 10 & 4 & 40,00 \\
\hline 7 & $0,2 \% \mathrm{PBC}$ & 10 & 7 & $\begin{array}{c}70,00 \\
p>0,05\end{array}$ & 6 & 3 & $\begin{array}{c}30,00 \\
p>0,05\end{array}$ & 10 & 6 & $\begin{array}{c}60,00 \\
p>0,05\end{array}$ \\
\hline 8 & $0,2 \% \mathrm{PBC}+\mathrm{Y} 3$ & 10 & 8 & $\begin{array}{l}80,00 \\
p>0,05\end{array}$ & 6 & 3 & $\begin{array}{c}50,00 \\
p>0,05\end{array}$ & 10 & 7 & $\begin{array}{c}70,00 \\
p>0,05\end{array}$ \\
\hline 9 & $\begin{array}{l}0,2 \% \mathrm{PBC}+\mathrm{БT}+ \\
\text { У3 }\end{array}$ & 10 & 10 & $\begin{array}{c}100 \\
p<0,01\end{array}$ & 7 & 7 & $\begin{array}{c}100 \\
p<0,02\end{array}$ & 10 & 10 & $\begin{array}{c}100 \\
p<0,01\end{array}$ \\
\hline 10 & $\begin{array}{l}0,2 \% \mathrm{PBC}+\mathrm{Y} 3+ \\
\text { БТ }\end{array}$ & 10 & 10 & $\begin{array}{c}100 \\
p<0,01\end{array}$ & 6 & 6 & $\begin{array}{c}100 \\
\mathrm{p}<0,05\end{array}$ & 10 & 10 & $\begin{array}{c}100 \\
p<0,01\end{array}$ \\
\hline
\end{tabular}

Примечание: $\mathrm{p}$ - достоверность различий по отношению к 6 подгруппе

Анализ данных таблиц показал, что в шестой подгруппе, где пациенты с ОВПСЭ корневых каналов зубов обрабатывались $0,2 \%$ РХГ, боль в области причинного зуба прекратилась только у четырех пациентов (40,00\%). 
Уменьшилась асимметрия лица, гиперемия и отек десны, установлена безболезненная перкуссия также в 40,00\% случаев. Болезненная перкуссия соседних зубов снизилась на $25,00 \%$. Прекращение экссудации из корневых каналов зарегистрировано у трех больных $(30,00 \%)$. В восьмой подгруппе под воздействием РВС и УЗ прекратились боли и экссудация из корневых каналов в 80,00\% случаев, уменьшилась асимметрия лица у 50,00\% пациентов, исчезла гиперемия и отек у 70,00\% больных, безболезненная перкуссия причинного зуба определялась в $70,00 \%$ случаев.

Значительно лучше купировались явления острого воспаления в сроки 35 дней у пациентов девятой и десятой подгрупп, где в сочетании с озвученным РВС, которым обрабатывались корневые каналы, чрезкожно применялся поляризованный свет «Bioptron».

Таблица 15

Изменение клинических признаков острого воспаления в

периапикальных тканях под воздействием различных лечебных комплексов у больных с ОВПСЭ (вторая группа)

\begin{tabular}{|c|c|c|c|c|c|c|c|}
\hline \multirow{4}{*}{ 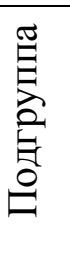 } & \multirow{4}{*}{$\begin{array}{c}\text { Комплекс } \\
\text { лечебных } \\
\text { воздействий }\end{array}$} & \multicolumn{6}{|c|}{ Купирование симптомов острого воспаления } \\
\hline & & \multicolumn{3}{|c|}{$\begin{array}{c}\text { Болезненная перкуссия } \\
\text { причинного зуба }\end{array}$} & \multicolumn{3}{|c|}{$\begin{array}{c}\text { Прекращения явлений } \\
\text { экссудации }\end{array}$} \\
\hline & & \multirow[t]{2}{*}{ до } & \multicolumn{2}{|c|}{ после } & \multirow[t]{2}{*}{ до } & \multicolumn{2}{|c|}{ после } \\
\hline & & & абс. & $\%$ & & абс. & $\%$ \\
\hline 6 & $0,2 \% \mathrm{PX} \Gamma$ & 10 & 4 & 40,00 & 10 & 3 & 30,00 \\
\hline 7 & $0,2 \% \mathrm{PBC}$ & 10 & 6 & $\begin{array}{c}60,00 \\
p>0,05\end{array}$ & 10 & 5 & $\begin{array}{c}50,00 \\
p>0,05\end{array}$ \\
\hline 8 & $0,2 \% \mathrm{PBC}+\mathrm{Y} 3$ & 10 & 7 & $\begin{array}{l}70,00 \\
p>0,05\end{array}$ & 10 & 8 & $\begin{array}{c}80,00 \\
\mathrm{p}<0,02\end{array}$ \\
\hline 9 & $0,2 \% \mathrm{PBC}+\mathrm{БТ}+\mathrm{Y3}$ & 10 & 10 & $\begin{array}{c}100 \\
p<0,01\end{array}$ & 10 & 10 & $\begin{array}{c}100 \\
p<0,01\end{array}$ \\
\hline 10 & $0,2 \% \mathrm{PBC}+\mathrm{Y} 3+\mathrm{БT}$ & 10 & 10 & $\begin{array}{c}100 \\
p<0,01\end{array}$ & 10 & 10 & $\begin{array}{c}100 \\
p<0,01\end{array}$ \\
\hline
\end{tabular}

Примечание: $\mathrm{p}$ - достоверность различий по отношению к 6 подгруппе

Как в девятой, так и в десятой подгруппах после 2-4 процедур света «Bioptron» все явления острого воспаления в периодонте были купированы в 100\% случаев и корневые каналы были готовы к пломбированию, которое осуществлялось после снятия всех явлений острого воспаления. Следовательно, наилучшие показатели зафиксированы в девятой и десятой 
подгруппах, где применялись в комплексе велтосепт и «Bioptron»; велтосепт, ультразвук, «Bioptron» соответственно.

4.2.3. Сравнительная оценка эффективности использования различных пломбировочных материалов при лечении ОВПСЭ

К неблагоприятным результатам относились те случаи, когда предъявлялись жалобы на боль, патологическую подвижность зуба, гиперемию и отечность слизистой оболочки десны, которые не исчезли по прошествии трех дней после пломбирования. Для сравнительной оценки эффективности используемых пломбировочных материалов для лечения ОВПСЭ произведен анализ ближайших осложнений после пломбирования корневых каналов зубов (таблица 16 и 17). Интерпретация данных таблиц 16 и 17 показала, что осложнения в ближайшие сроки после лечения у больных с ОВПСЭ наблюдались в зависимости от используемого пломбировочного материала, способов санации системы корневых каналов. Так в шестой подгруппе, где каналы пломбировались ЭВ традиционным методом в комплексе с ирригантом - РХГ, наблюдался наибольший процент осложнений $(80,00 \%)$ случаев.

Таблица 16

Лечебные комплексы воздействия у пациентов с ОВПСЭ

\begin{tabular}{|c|c|c|c|c|}
\hline \multirow{2}{*}{$\begin{array}{l}\text { Подгр } \\
\text { уппа }\end{array}$} & \multirow{2}{*}{\begin{tabular}{l} 
зул-во \\
\cline { 3 - 5 }
\end{tabular}} & \multicolumn{3}{|c|}{ Комплекс лечебных воздействий } \\
\cline { 3 - 5 } & Медикаментозное & Физическое & $\begin{array}{c}\text { Пломбировочный } \\
\text { материал }\end{array}$ \\
\hline 6 & 10 & $0,2 \%$ РХГ & - & ЭВ \\
\hline 7 & 10 & $0,2 \%$ РВС & - & ВСП № 1 \\
\hline 8 & 10 & $0,2 \%$ РВС & У3 & ВСП № 1+ГШ \\
\hline 9 & 10 & $0,2 \%$ РВС & УЗ+БТ & ВСПОИ № 2+ ГШ \\
\hline 10 & 10 & $0,2 \%$ РВС & У3+БТ & ОТ-«Кальсепт»+ВСПОИ № 2+ГШ \\
\hline
\end{tabular}

Данные осложнения у пациентов с ОВПСЭ выражались в боли при перкуссии и накусывании на причинный зуб, гиперемии и отека мягких тканей, сглаженности переходной складки и асимметрии лица за счет припухлости мягких тканей в области причинного зуба.

В седьмой подгруппе, где применялся лечебный комплекс, состоящий из медикаментозной обработки системы корневых каналов 0,2\% РВС и 
пломбированием их ВСП № 1 ТР, осложнения после пломбирования возникли в 40,00\% в виде боли при накусывании на причинный зуб, гиперемии и отечности десны, у двух из них отмечалась асимметрия лица.

Таблица 17

Клинические данные после пломбирования корневых каналов у пациентов с ОВПСЭ различными эндодонтическими материалами (вторая группа)

\begin{tabular}{|c|c|c|c|c|c|c|c|c|c|}
\hline \multirow{3}{*}{ 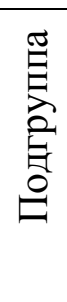 } & \multirow{3}{*}{$\begin{array}{l}\text { Кол- } \\
\text { во } \\
\text { зубов }\end{array}$} & \multirow{2}{*}{\multicolumn{2}{|c|}{$\begin{array}{c}\text { Осложнения } \\
\text { после } \\
\text { пломбирования }\end{array}$}} & \multicolumn{6}{|c|}{ Клинические симптомы } \\
\hline & & & & \multicolumn{2}{|c|}{$\begin{array}{c}\text { Боль при } \\
\text { перкуссии и } \\
\text { накусывании на } \\
\text { причинный зуб }\end{array}$} & \multicolumn{2}{|c|}{$\begin{array}{c}\text { Гиперемия, отек } \\
\text { мягких тканей }\end{array}$} & \multicolumn{2}{|c|}{$\begin{array}{c}\text { Сглаженность } \\
\text { переходной } \\
\text { складки }\end{array}$} \\
\hline & & абс & $\%$ & абс & $\%$ & абс & $\%$ & абс & $\%$ \\
\hline 6 & 10 & 8 & 80,00 & 8 & 80,00 & 8 & 80,00 & 5 & 50,00 \\
\hline 7 & 10 & 4 & $\begin{array}{c}40,00 \\
p>0,05\end{array}$ & 4 & $\begin{array}{l}40,00 \\
p>0,05\end{array}$ & 4 & $\begin{array}{l}40,00 \\
p>0,05\end{array}$ & 1 & $\begin{array}{l}10,00 \\
p>0,05\end{array}$ \\
\hline 8 & 10 & 2 & $\begin{array}{l}20,00 \\
p<0,01\end{array}$ & 2 & $\begin{array}{l}20,00 \\
p<0,01\end{array}$ & 2 & $\begin{array}{c}20,00 \\
\mathrm{p}<0,01\end{array}$ & 0 & $\begin{array}{c}0,00 \\
p<0,01\end{array}$ \\
\hline 9 & 10 & 0 & $\begin{array}{c}0,00 \\
p<0,01\end{array}$ & 0 & $\begin{array}{c}0,00 \\
p<0,01\end{array}$ & 0 & $\begin{array}{c}0,00 \\
p<0,01\end{array}$ & 0 & $\begin{array}{c}0,00 \\
p<0,01\end{array}$ \\
\hline 10 & 10 & 0 & $\begin{array}{c}0,00 \\
\mathrm{p}<0,01\end{array}$ & 0 & $\begin{array}{c}0,00 \\
p<0,01\end{array}$ & 0 & $\begin{array}{c}0,00 \\
\mathrm{p}<0,01\end{array}$ & 0 & $\begin{array}{c}0,00 \\
\mathrm{p}<0,01\end{array}$ \\
\hline
\end{tabular}

Примечание: $\mathrm{p}$ - достоверность различий по отношению к 6 подгруппе

В восьмой подгруппе корневые каналы зубов после медикаментозной обработки 0,2\% РВС и УЗ, пломбировались так же ВСП № 1 с ГШ ТР. В данной подгруппе осложнения возникли у двух пациентов в виде болезненности при накусывании на причинный зуб с положительной вертикальной перкуссией, гиперемией и отечностью слизистой оболочки десны.

Наиболее высокие результаты достигнуты в девятой и десятой подгруппах, где в комплекс лечебных воздействий включены озвученный PBC, паста с гидроксиапатитом «Остеоиндуцин» в девятой подгруппе ТР и в десятой подгруппе, где проводилась временная обтурация корневых каналов материалом «Кальсепт», который через месяц заменялся ВСПОИ №2 с ГШ. До и после пломбирования применялся биостимулирующий свет «Bioptron». Вышеперечисленные осложнения после пломбирования каналов и воздействия 2-3 сеансов света «Bioptron» в этих подгруппах отсутствовали. 


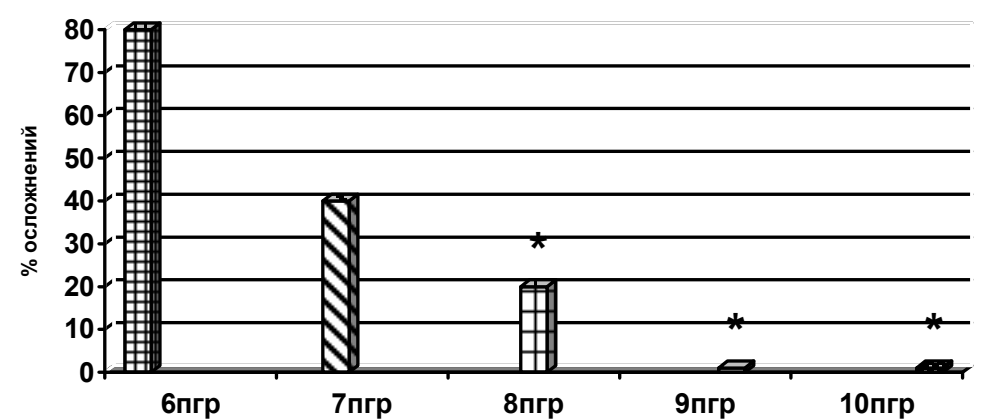

田 $0,2 \% \mathrm{PX} \Gamma+Э \mathrm{~B}$

จ $0,2 \%$ РВС+ВСП№1

日 $0,2 \%$ РВС+УЗ+ВСП№1+ГШ

$\square$ $2 \%$ РВС+БТ+ВСПОИ№2+ГШ

2. $0,2 \%$ РВС+УЗ+БТ+ВСПОИ№2+ГШ

Примечание: *p<0,01 по отношению к 6-ой подгруппе

Рис.9. Сравнительная характеристика осложнений после лечения ОВПСЭ различными лечебными комплексами (вторая группа)

Таким образом, анализ данных клинических результатов применения паст, содержащих велтосепт и нанодисперсный гидроксиапатит «Остеоиндуцин» в комплексе со светом «Вioptron» для пломбирования корневых каналов при острых периодонтитах в стадии экссудации как ТР, так и ОТ свидетельствуют о положительном влиянии этих паст на патологический очаг воспаления в периодонте в ближайшие сроки наблюдения (рис.9).

\subsection{1. Клиническая характеристика и рентгенологические данные у больных с ОХВГрП до лечения (третья группа)}

В третью группу были подобраны 50 пациентов с ОХВГрП, которые также были разделены на 5 подгрупп в зависимости от комплекса лечебных воздействий. Клинические данные обострившихся хронических гранулирующих периодонтитов представлены в таблицах 18 и 19. Во всех подгруппах была идентичная клиническая картина.

Так, в 11 подгруппе все больные жаловались на постоянную, ноющую, усиливающуюся боль причинного зуба, боль при накусывании (симптом «выросшего зуба») и боль, возникающую при прикосновении языком. Из них 80,00\% предъявляли жалобы на головную боль и недомогание, у некоторых (60,00\%) пациентов установлено повышение температуры тела до $38^{0} \mathrm{C}$ с потерей трудоспособности. 
Таблица 18

Субъективные клинические проявления у больных с ОХВГрП до лечения (третья группа)

\begin{tabular}{|c|c|c|c|c|c|c|c|}
\hline \multirow{2}{*}{$\begin{array}{l}\text { Под- } \\
\text { груп } \\
\text { па }\end{array}$} & \multirow{2}{*}{$\begin{array}{l}\text { Кол-во } \\
\text { боль- } \\
\text { ных/ } \\
\text { зубов }\end{array}$} & & \multicolumn{5}{|c|}{ Субъективные данные } \\
\hline & & & $\begin{array}{c}\text { Боль при } \\
\text { чинного зуба } \\
\text { постоянная }\end{array}$ & $\begin{array}{c}\text { Симптом } \\
\text { «вырос- } \\
\text { шего» зуба }\end{array}$ & $\begin{array}{c}\text { Боль } \\
\text { головная }\end{array}$ & $\begin{array}{c}\text { Повышение } \\
\text { t тела до } \\
39^{0} \mathrm{C}\end{array}$ & $\begin{array}{c}\text { Потеря } \\
\text { трудоспо- } \\
\text { собности }\end{array}$ \\
\hline \multirow[t]{2}{*}{11} & \multirow[t]{2}{*}{$10 / 10$} & абс. & 10 & 10 & 8 & 6 & 6 \\
\hline & & $\%$ & 100 & 100 & 80,00 & 60,00 & 60,00 \\
\hline \multirow[t]{2}{*}{12} & \multirow[t]{2}{*}{$10 / 10$} & абс. & 10 & 10 & 10 & 7 & 7 \\
\hline & & $\%$ & 100 & 100 & 100 & 70,00 & 70,00 \\
\hline \multirow[t]{2}{*}{13} & \multirow[t]{2}{*}{$10 / 10$} & абс. & 10 & 10 & 7 & 7 & 7 \\
\hline & & $\%$ & 100 & 100 & 70,00 & 70,00 & 70,00 \\
\hline \multirow[t]{2}{*}{14} & \multirow[t]{2}{*}{$10 / 10$} & абс. & 10 & 9 & 8 & 5 & 5 \\
\hline & & $\%$ & 100 & 90,00 & 80,00 & 50,00 & 50,00 \\
\hline \multirow[t]{2}{*}{15} & \multirow[t]{2}{*}{$10 / 10$} & абс. & 10 & 10 & 9 & 6 & 6 \\
\hline & & $\%$ & 100 & 100 & 90,00 & 60,00 & 60,00 \\
\hline
\end{tabular}

Объективно определялся коллатеральный отек мягких тканей лица с асимметрией лица со стороны причинного зуба у пяти пациентов. При пальпации у всех больных определялись увеличенные и болезненные регионарные лимфатические железы, отмечалась гиперемия и отек десны и переходной складки в области причинного зуба. Перкуторная реакция причинного зуба у всех пациентов была болезненна, а у шести из них - и соседних зубов.

Таблица 19

\section{Объективные клинические данные у больных с ОХВГрП до лечения}

\section{(третья группа)}

\begin{tabular}{|c|c|c|c|c|c|c|c|c|}
\hline \multirow{2}{*}{ 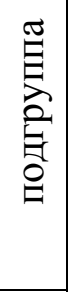 } & \multirow[b]{2}{*}{$\begin{array}{l}\text { Кол-во } \\
\text { боль- } \\
\text { ных } \\
\text { /зу- } \\
\text { бов }\end{array}$} & & \multicolumn{5}{|c|}{ Объективные клинические проявления } & \multirow[b]{2}{*}{$\begin{array}{c}\text { Периа- } \\
\text { пикаль- } \\
\text { ный } \\
\text { индекс } \\
\text { PAI, } \\
\text { баллы }\end{array}$} \\
\hline & & & $\begin{array}{l}\text { Коллате- } \\
\text { ральный } \\
\text { отек }\end{array}$ & $\begin{array}{l}\text { Увеличение } \\
\text { болезнен- } \\
\text { ности } \\
\text { лимфоузлов }\end{array}$ & $\begin{array}{l}\text { Гиперемия } \\
\text { и отеность } \\
\text { десны при- } \\
\text { чинного } \\
\text { зуба } \\
\end{array}$ & $\begin{array}{c}\text { Перкутор- } \\
\text { ная реак- } \\
\text { ция при- } \\
\text { чинного } \\
\text { зуба } \\
\end{array}$ & $\begin{array}{c}\text { Наличие } \\
\text { экссудата } \\
\text { в каналах }\end{array}$ & \\
\hline \multirow[t]{2}{*}{11} & $10 /$ & абс. & 5 & 10 & 10 & 10 & 10 & \multirow[t]{2}{*}{4} \\
\hline & 10 & $\%$ & 50,00 & 100 & 100 & 100 & 100 & \\
\hline \multirow[t]{2}{*}{12} & $10 /$ & абс. & 6 & 10 & 10 & 10 & 10 & \multirow[t]{2}{*}{4} \\
\hline & 10 & $\%$ & 60,00 & 100 & 100 & 100 & 100 & \\
\hline \multirow[t]{2}{*}{13} & $10 /$ & абс. & 7 & 10 & 10 & 10 & 10 & \multirow[t]{2}{*}{4} \\
\hline & 10 & $\%$ & 70,00 & 100 & 100 & 100 & 100 & \\
\hline \multirow[t]{2}{*}{14} & $10 /$ & абс. & 6 & 10 & 10 & 10 & 10 & \multirow[t]{2}{*}{4} \\
\hline & 10 & $\%$ & 60,00 & 100 & 100 & 100 & 100 & \\
\hline \multirow[t]{2}{*}{15} & $10 /$ & абс. & 6 & 10 & 10 & 10 & 10 & \multirow[t]{2}{*}{4} \\
\hline & 10 & $\%$ & 60,00 & 100 & 100 & 100 & 100 & \\
\hline
\end{tabular}


В 12 подгруппе с ОХВГрП при обращении к лечащему врачу все больные предъявляли жалобы на резкую ноющую постоянную боль, боль при накусывании на причинный зуб и головную боль с недомоганием, семь из них жаловались на повышение температуры тела и потерю трудоспособности. При осмотре у шести пациентов установлен коллатеральный отек мягких тканей с асимметрией лица со стороны причинного зуба. У всех больных пальпаторно определялись увеличенные и болезненные лимфоузлы с гиперемией и отечностью десны в области причинного зуба. Перкуторная реакция у всех пациентов была резко болезненной, у семи из них - и соседних зубов.

В 13 подгруппе жалобы на постоянную ноющую боль, боль при накусывании на причинный зуб предъявляли все 10 пациентов. Семь из них жаловалась и на головную боль с повышением температуры тела и потерей трудоспособности. При объективном исследовании была выявлена резкая перкуторная реакция всех причинных зубов, у восьми из них - и соседних зубов с увеличением и болезненностью при пальпации регионарных лимфоузлов, с коллатеральным отеком мягких тканей, гиперемией и отеком слизистой оболочки десны.

В 14 подгруппе все 10 пациентов жаловались на постоянную ноющую боль и боль при накусывании на больной зуб с явлениями общей интоксикации: у 9 (90,00\%) из них были жалобы на головную боль, у шести $(60,00 \%)$ с повышением температуры тела и потерей трудоспособности. Объективно установлена асимметрия лица за счет коллатерального отека у шести пациентов. Увеличение и болезненность регионарных лимфоузлов, гиперемия и отечность десны, болезненная перкуторная реакция установлена у всех больных, у семи из них отмечалась болезненная перкуторная реакция соседних зубов.

В 15 подгруппе 10 пациентов предъявляли жалобы на постоянную ноющую боль причинного зуба, чувство «выросшего зуба» и боль при накусывании на больной зуб, а также на головную боль и повышение 
температуры тела, у шести из них - с потерей трудоспособности. При осмотре у шести из них зарегистрирована асимметрия лица, увеличение лимфоузлов, гиперемия и отечность слизистой оболочки установлена у всех пациентов, а также установлена болезненная перкуссия соседних зубов. У всех пациентов третьей группы при инструментальной обработке корневых каналов было зафиксировано наличие экссудата из них. При прогрессировании воспалительного процесса нарушается непрерывность кортикальной пластинки, наблюдается истончение костных оболочек в виде участков разряжения без четких границ. Рентгенологически согласно периапикальному индексу PAI деструктивные изменения костных структур в околоверхушечной области при хронических гранулирующих периодонтитах оцениваются четырьмя баллами.

\subsection{2 Ближайшие результаты лечения обострившихся хронических верхушечных гранулирующих периодонтитов различными лечебными комплексами}

В 11 подгруппе, где корневые каналы обрабатывались 0,2\% РХГ, боли в течение 3-5 дней прекратились у шести пациентов (60,00\%), уменьшилась асимметрия лица у трех обследованных из четырех до лечения, исчезла гиперемия и отек у 40,00\% больных. Безболезненная перкуссия причинного и соседних зубов установлена у четырех (40,00\%) больных. Прекращение экссудации из корневых каналов было так же у четырех из десяти до лечения (табл. 20 и 21).

В 12 подгруппе, где пациентам каналы после инструментальной обработки обрабатывались ирригантом 0,2\% велтосептом, боли прекратились в ближайшие сроки наблюдений в 70,00\% случаев, уменьшилась асимметрия лица у трех (75,00\%) больных из четырех до лечения, исчезла гиперемия и отечность в 60,00\% случаев, безболезненная перкуторная реакция причинного зуба установлена в 60,00\% случаев, соседних зубов - в 75,00\% случаев, прекратились выделения экссудата из корневых каналов у 60,00\% пациентов. 
Таблица 20

Динамика клинических признаков острого воспаления в периапикальных тканях под воздействием различных лечебных комплексов у больных с ОХВГрП (третья группа)

\begin{tabular}{|c|c|c|c|c|c|c|c|c|c|c|}
\hline \multirow{4}{*}{$\begin{array}{c}\text { Под- } \\
\text { групп- } \\
\text { па }\end{array}$} & \multirow{4}{*}{$\begin{array}{c}\text { Комплекс } \\
\text { лечебных } \\
\text { воздействий }\end{array}$} & \multicolumn{9}{|c|}{ Купирование симптомов острого воспаления } \\
\hline & & \multicolumn{3}{|c|}{ Прекращение боли } & \multicolumn{3}{|c|}{$\begin{array}{c}\text { Уменьшение } \\
\text { асимметрии лица }\end{array}$} & \multicolumn{3}{|c|}{$\begin{array}{c}\text { Исчезновение } \\
\text { гиперемии и } \\
\text { отечности десны }\end{array}$} \\
\hline & & \multirow[t]{2}{*}{ до } & \multicolumn{2}{|r|}{ после } & \multirow[t]{2}{*}{ до } & \multicolumn{2}{|r|}{ после } & \multirow[t]{2}{*}{ до } & \multicolumn{2}{|r|}{ после } \\
\hline & & & aбc. & $\%$ & & aбc. & $\%$ & & абс. & $\%$ \\
\hline 11 & $0,2 \%$ РХГ & 10 & 6 & 60,00 & 4 & 3 & 75,00 & 10 & 4 & 40,00 \\
\hline 12 & $0,2 \% \mathrm{PBC}$ & 10 & 7 & $\begin{array}{c}70,00 \\
p>0,05\end{array}$ & 4 & 3 & 75,00 & 10 & 6 & $\begin{array}{l}60,00 \\
p>0,05\end{array}$ \\
\hline 13 & $0,2 \% \mathrm{PBC}+\mathrm{Y} 3$ & 10 & 8 & $\begin{array}{c}80,00 \\
p>0,05\end{array}$ & 5 & 4 & $\begin{array}{c}80,00 \\
p>0,05\end{array}$ & 10 & 8 & $\begin{array}{c}80,00 \\
p>0,05\end{array}$ \\
\hline 14 & $\begin{array}{l}0,2 \% \mathrm{PBC}+\mathrm{Y3}+ \\
\mathrm{6T}\end{array}$ & 10 & 10 & $\begin{array}{c}100 \\
p<0,05\end{array}$ & 4 & 4 & $\begin{array}{c}100 \\
p>0,05\end{array}$ & 10 & 10 & $\begin{array}{c}100 \\
p<0,01\end{array}$ \\
\hline 15 & $\begin{array}{l}0,2 \% \mathrm{PBC}+\mathrm{Y} 3+ \\
\text { БТ }\end{array}$ & 10 & 10 & $\begin{array}{c}100 \\
p<0,05\end{array}$ & 5 & 5 & $\begin{array}{c}100 \\
p>0,05\end{array}$ & 10 & 10 & $\begin{array}{c}100 \\
p<0,01\end{array}$ \\
\hline
\end{tabular}

Примечание: $\mathrm{p}$ - достоверность различий по отношению к 6 подгруппе

В 13 подгруппе, где каналы обрабатывались 0,2\% раствором велтосепта и ультразвуком, боли в области причинного зуба прекратились у 80,00\% больных, уменьшились асимметрия лица у четырех пациентов из пяти до лечения, а так же исчезла гиперемия и отечность десны в $80,00 \%$ случаев. Установлена болезненная перкуссия соседних зубов у 80,00\% пациентов, прекратилась экссудация из корневых каналов также у 80,00\% больных.

Таблица 21

\section{Изменение клинических признаков острого воспаления в} периапикальных тканях под воздействием различных лечебных комплексов у больных с ОХВГрП (третья группа)

\begin{tabular}{|c|c|c|c|c|c|c|c|}
\hline \multirow{4}{*}{$\begin{array}{l}\text { Под- } \\
\text { группа }\end{array}$} & \multirow{4}{*}{$\begin{array}{l}\text { Комплекс } \\
\text { лечебных } \\
\text { воздействий }\end{array}$} & \multicolumn{6}{|c|}{ Купирование симптомов острого воспаления } \\
\hline & & \multicolumn{3}{|c|}{$\begin{array}{c}\text { Болезненная перкуссия } \\
\text { причинного зуба }\end{array}$} & \multicolumn{3}{|c|}{$\begin{array}{c}\text { Прекращения явлений } \\
\text { экссудации }\end{array}$} \\
\hline & & \multirow{2}{*}{ до } & \multicolumn{2}{|c|}{ после } & \multirow{2}{*}{ до } & \multicolumn{2}{|c|}{ после } \\
\hline & & & абс. & $\%$ & & абс. & $\%$ \\
\hline 11 & $0,2 \%$ РХГ & 10 & 4 & 40,00 & 10 & 4 & 40,00 \\
\hline 12 & $0,2 \% \mathrm{PBC}$ & 10 & 6 & $\begin{array}{c}60,00 \\
p>0,05\end{array}$ & 10 & 6 & $\begin{array}{c}60,00 \\
p>0,05\end{array}$ \\
\hline 13 & $0,2 \% \mathrm{PBC}+\mathrm{Y} 3$ & 10 & 8 & $\begin{array}{c}80,00 \\
\mathrm{p}>0,05\end{array}$ & 10 & 8 & $\begin{array}{c}80,00 \\
p>0,05\end{array}$ \\
\hline 14 & $0,2 \%$ РBC+БТ & 10 & 10 & $\begin{array}{c}100 \\
\mathrm{p}<0,01\end{array}$ & 10 & 10 & $\begin{array}{c}100 \\
p<0,01\end{array}$ \\
\hline 15 & $0,2 \%$ РВС+УЗ+БТ & 10 & 10 & $\begin{array}{c}100 \\
\mathrm{p}<0,01\end{array}$ & 10 & 10 & $\begin{array}{c}100 \\
p<0,01\end{array}$ \\
\hline
\end{tabular}

Примечание: $\mathrm{p}$ - достоверность различий по отношению к 6 подгруппе 
В 14 подгруппе под воздействием озвученного 0,2\% раствора велтосепта и поляризованного света «Bioptron» явления были купированы в 100\% случаев после воздействия двумя полями 2-3 сеансов биостимулирующего света «Bioptron» в ближайшие трое суток. В 15 подгруппе комплекс лечебных воздействий состоял из озвученного антисептика $0,2 \%$ раствора велтосепта и поляризованного света «Bioptron». Все явления воспаления в периодонте так же были купированы в течение 3 суток. Таким образом, клиническое состояние периодонта при лечении обострившихся хронических гранулирующих периодонтитов различными комплексами позволяли установить, что наилучшие результаты были достигнуты при включении в комплекс лечебных воздействий биостимулирующего света «Bioptron» (14 и 15 подгруппы).

\subsection{3 Сравнительная оценка эффективности воздействия на периодонт различных пломбировочных материалов}

Анализ ближайших осложнений, связанных с пломбированием корневых каналов после купирования острых явлений в периодонте у больных с ОХВГрП представлены в таблице 22 и 23.

Таблица 22

Лечебные комплексы воздействия у пациентов с ОХВГрП (третья группа)

\begin{tabular}{|c|c|c|c|c|c|}
\hline \multirow{2}{*}{$\begin{array}{l}\text { Под- } \\
\text { груп- } \\
\text { па }\end{array}$} & \multirow{2}{*}{$\begin{array}{l}\text { Кол- } \\
\text { во } \\
\text { зубов }\end{array}$} & \multirow{2}{*}{$\begin{array}{l}\text { Ме- } \\
\text { тод }\end{array}$} & \multicolumn{3}{|c|}{ Комплекс лечебных воздействий } \\
\hline & & & Медикаментозное & Физическое & Пломбировочный материал \\
\hline 11 & 10 & TP & $0,2 \%$ РХГ & - & ЭВ \\
\hline 12 & 10 & TP & $0,2 \% \mathrm{PBC}$ & - & ВСП № 1 \\
\hline 13 & 10 & $\mathrm{TP}$ & $0,2 \% \mathrm{PBC}$ & У3 & ВСП №1 ГШ \\
\hline 14 & 10 & $\mathrm{TP}$ & $0,2 \% \mathrm{PBC}$ & УЗ+БТ & ВСПОИ № $2+$ ГШ \\
\hline 15 & 10 & OT & $0,2 \% \mathrm{PBC}$ & УЗ+БТ & ОТ-«Кальсепт» + ВСПОИ №2 + ГШ \\
\hline
\end{tabular}

При лечении деструктивных форм ОХВГрП наибольший процент осложнений зарегистрирован в 11 подгруппе при пломбировании каналов ЭВ (70,00\% больных), которые жаловались на боль при накусывании на причинный зуб. При осмотре установлена гиперемия и отечность слизистой оболочки и болезненная перкуторная реакция у 7 (70,00\%) больных, 
наблюдалась сглаженность переходной складки с асимметрией лица за счет коллатерального отека мягких тканей лица.

В 12 и 13 подгруппе, где каналы пломбировались предложенной нами ВСП № 1 осложнения возникли в трех и двух случаях соответственно в виде болезненности при накусывании на причинный зуб. Объективно установлена гиперемия десны и болезненная перкуторная реакция причинного зуба.

В 14 подгруппе после медикаментозной обработки каналов 0,2\% РВС и УЗ, пломбирование проводилось ВСПОИ № 2 и гуттаперчевыми штифтами традиционным методом. До и после пломбирования был применен свет «Bioptron». Осложнений после применения данного комплекса лечебных воздействий не зарегистрировано ни в одном случае.

Таблица 23

\section{Клинические данные после пломбирования корневых каналов у пациентов с ОХВГрП различными эндодонтическими материалами (третья группа)}

\begin{tabular}{|c|c|c|c|c|c|c|c|c|c|c|}
\hline \multirow{3}{*}{\begin{tabular}{|l|}
$\Pi$ \\
$\mathrm{O}$ \\
$Д$ \\
$\Gamma$ \\
$\mathrm{P}$ \\
$\mathrm{y}$ \\
$\Pi$ \\
$\Pi$ \\
$\mathrm{A}$
\end{tabular}} & \multirow{3}{*}{$\begin{array}{l}\text { Кол- } \\
\text { во } \\
\text { зу- } \\
\text { бов }\end{array}$} & \multirow{3}{*}{$\begin{array}{l}\mathrm{M} \\
\mathrm{E} \\
\mathrm{T} \\
\mathrm{O} \\
\text { Д }\end{array}$} & \multirow{2}{*}{\multicolumn{2}{|c|}{$\begin{array}{c}\text { Осложнения } \\
\text { после } \\
\text { пломбирования }\end{array}$}} & \multicolumn{6}{|c|}{ Клинические симптомы } \\
\hline & & & & & \multicolumn{2}{|c|}{$\begin{array}{c}\text { Боль при } \\
\text { перкуссии и } \\
\text { накусывании на } \\
\text { причинный зуб }\end{array}$} & \multicolumn{2}{|c|}{$\begin{array}{c}\text { Гиперемия, } \\
\text { отек мягких } \\
\text { тканей }\end{array}$} & \multicolumn{2}{|c|}{$\begin{array}{c}\text { Сглаженность } \\
\text { переходной } \\
\text { складки }\end{array}$} \\
\hline & & & абс & $\%$ & абс & $\%$ & aбc & $\%$ & абс & $\%$ \\
\hline 11 & 10 & $\mathrm{TP}$ & 7 & 70,00 & 7 & 70,00 & 7 & 70,00 & 5 & 50,00 \\
\hline 12 & 10 & $\mathrm{TP}$ & 3 & $\begin{array}{c}30,00 \\
p>0,05\end{array}$ & 3 & $\begin{array}{c}30,00 \\
p>0,05\end{array}$ & 3 & $\begin{array}{c}30,00 \\
p>0,05\end{array}$ & 0 & $\begin{array}{c}0,00 \\
p>0,05\end{array}$ \\
\hline 13 & 10 & $\mathrm{TP}$ & 2 & $\begin{array}{c}20,00 \\
p<0,02\end{array}$ & 2 & $\begin{array}{c}20,00 \\
p<0,02\end{array}$ & 2 & $\begin{array}{c}20,00 \\
p<0,02\end{array}$ & 0 & $\begin{array}{c}0,00 \\
p<0,01\end{array}$ \\
\hline 14 & 10 & $\mathrm{TP}$ & 0 & $\begin{array}{c}0,00 \\
p<0,01\end{array}$ & 0 & $\begin{array}{c}0,00 \\
p<0,01\end{array}$ & 0 & $\begin{array}{c}0,00 \\
p<0,01\end{array}$ & 0 & $\begin{array}{c}0,00 \\
p<0,01\end{array}$ \\
\hline 15 & 10 & OT & 0 & $\begin{array}{c}0,00 \\
\mathrm{p}<0,01\end{array}$ & 0 & $\begin{array}{c}0,00 \\
p<0,01\end{array}$ & 0 & $\begin{array}{c}0,00 \\
p<0,01\end{array}$ & 0 & $\begin{array}{c}0,00 \\
p<0,01\end{array}$ \\
\hline
\end{tabular}

Примечание: $\mathrm{p}$ - достоверность различий по отношению к 11 подгруппе

В 15 подгруппе после медикаментозного воздействия на микрофлору корневых каналов озвученным 0,2\% раствором велтосепта применялся отсроченный метод пломбирования их материалом «Кальсепт» с пролонгированным антисептическим действием на четыре недели с последующим постоянным пломбированием велтосепт-пастой № 2 с остеоиндуцином и гуттаперчевыми штифтами. Предупреждая возможные 
осложнения после пломбирования корневых каналов, применялся поляризованный свет «Bioptron». Применение данного комплекса лечебных воздействий на периодонт в сочетании со светом «Bioptron» осложнений после пломбирования каналов ни отсроченным («Кальсепт»), ни традиционным методом (ВСПОИ №2) не зарегистрировано, так как свет «Bioptron» (14 и 15 подгруппы) обладает мощным противовоспалительным и обезболивающим действием, предупреждает появление симптомов воспаления, «Кальсепт» и «Остеоиндуцин» так же способствуют предупреждению воспалительных явлений за счет пролонгированного антисептического действия.

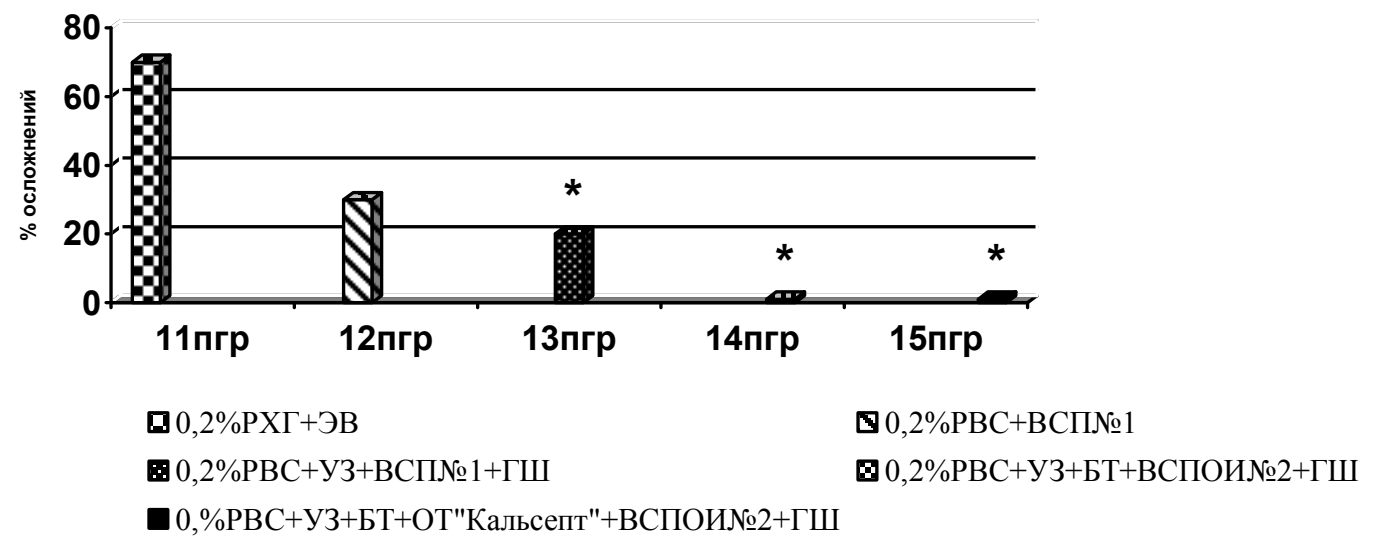

Примечание: *p<0,01 по отношению к 11-ой подгруппе

Рис.10. Сравнительная характеристика осложнений после лечения ОХВГрП различными лечебными комплексами (третья группа)

Таким образом, анализ клинических данных после пломбирования корневых каналов у пациентов с ОХВГрП различными лечебными комплексами показал, что положительное влияние на периодонт в ближайшие сроки наблюдений оказывала ВСПОИ №2 как традиционным (14 ПГР), так и отсроченным (15 ПГР) методами, а также светотерапия «Bioptron» (рис. 10).

\footnotetext{
4.4.1. Клиническая характеристика и рентгенологические данные у больных с ОХВГП периодонтитами до лечения (четвертая группа)

В четвертую группу были подобраны 50 пациентов с обострившимися хроническими верхушечными гранулематозными периодонтитами (таблицы
} 
24, 25), которые были разделены на пять подгрупп (по 10 человек) в зависимости от комплекса лечебных воздействий $(16,17,18,19,20$ подгруппы).

Bсе пациенты 16 подгруппы жаловались на постоянную ноющую усиливающуюся боль, боль при накусывании на причинный зуб, семь из них дополнительно предъявляли жалобы на головную боль, недомогание, у четырех из них отмечалось повышение температуры тела до $38-38,5^{\circ} \mathrm{C}$ с потерей трудоспособности. При осмотре установлена асимметрия лица у четырех больных, асимметрия и отек десны и переходной складки у всех пациентов. Перкуссия причинного зуба была резко болезненной у всех пациентов, у 5 из них зарегистрирована перкуторная болезненная реакция соседних зубов.

Таблица 24

Субъективные клинические проявления у больных с ОХВГП до лечения (четвертая группа)

\begin{tabular}{|c|c|c|c|c|c|c|c|}
\hline \multirow{2}{*}{ 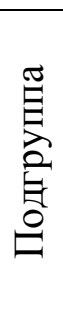 } & \multirow{2}{*}{$\begin{array}{l}\text { Коли- } \\
\text { чество } \\
\text { боль- } \\
\text { ных/ } \\
\text { зубов }\end{array}$} & & \multicolumn{5}{|c|}{ Субъективные данные } \\
\hline & & & $\begin{array}{c}\text { Боль } \\
\text { причинного } \\
\text { зуба } \\
\text { постоянная }\end{array}$ & $\begin{array}{c}\text { Симптом } \\
\text { «выросшего» } \\
\text { зуба }\end{array}$ & $\begin{array}{c}\text { Боль } \\
\text { головная }\end{array}$ & $\begin{array}{c}\text { Повышение } \\
\text { t тела до } \\
39^{0} \mathrm{C}\end{array}$ & $\begin{array}{c}\text { Потеря } \\
\text { трудоспо- } \\
\text { собности }\end{array}$ \\
\hline \multirow[t]{2}{*}{16} & \multirow[t]{2}{*}{$10 / 10$} & абс. & 10 & 10 & 7 & 4 & 4 \\
\hline & & $\%$ & 100 & 100 & 70,00 & 40,00 & 40,00 \\
\hline \multirow[t]{2}{*}{17} & \multirow{2}{*}{$10 / 10$} & абс. & 10 & 10 & 6 & 2 & 2 \\
\hline & & $\%$ & 100 & 100 & 60,00 & 20,00 & 20,00 \\
\hline \multirow[t]{2}{*}{18} & \multirow[t]{2}{*}{$10 / 10$} & абс. & 10 & 10 & 5 & 5 & 5 \\
\hline & & $\%$ & 100 & 100 & 50,00 & 50,00 & 50,00 \\
\hline \multirow[t]{2}{*}{19} & \multirow[t]{2}{*}{$10 / 10$} & абс. & 10 & 10 & 8 & 4 & 4 \\
\hline & & $\%$ & 100 & 100 & 80,00 & 40,00 & 40,00 \\
\hline \multirow[t]{2}{*}{20} & \multirow[t]{2}{*}{$10 / 10$} & абс. & 10 & 10 & 9 & 5 & 5 \\
\hline & & $\%$ & 100 & 100 & 90,00 & 50,00 & 50,00 \\
\hline
\end{tabular}

В 17 подгруппе при обострившихся гранулематозных периодонтитах больные предъявляли жалобы на непрерывную ноющую боль, боль при накусывании на причинный зуб с явлениями интоксикации. У 6 пациентов наблюдались головная боль и недомогание, у 2 из них была повышена температура тела с потерей трудоспособности. Объективно установлена асимметрия лица за счет коллатерального отека у четырех больных, 
гиперемия и отек десны и переходной складки - у всех 10 обследованных пациентов. Резкая болезненная перкуторная реакция причинного зуба отмечалась у всех больных, соседних зубов - в семи из них.

В 18 подгруппе все 10 пациентов жаловались на постоянную ноющую боль, боль при накусывании на причинный зуб. Головную боль, повышение температуры тела с потерей трудоспособности жаловались пять пациентов. При осмотре асимметрия лица зарегистрирована у пяти обследованных, гиперемия, отек десны и переходной складки, а также резко болезненная перкуторная реакция причинного зуба и болезненность соседних зубов - у всех пациентов.

Таблица 25

Объективные клинические данные у больных с ОХВГП до лечения (четвертая группа)

\begin{tabular}{|c|c|c|c|c|c|c|c|c|}
\hline \multirow[b]{2}{*}{ 息 } & \multirow{2}{*}{$\begin{array}{l}\text { Кол-во } \\
\text { боль- } \\
\text { ных } \\
\text { /зубов }\end{array}$} & & \multicolumn{5}{|c|}{ Объективные клинические проявления } & \multirow[b]{2}{*}{$\begin{array}{c}\text { Периапи- } \\
\text { кальный } \\
\text { индекс } \\
\text { PAI, } \\
\text { баллы }\end{array}$} \\
\hline & & & $\begin{array}{c}\text { Асим- } \\
\text { метрия } \\
\text { лица }\end{array}$ & $\begin{array}{l}\text { Увеличение } \\
\text { болезнен- } \\
\text { ности } \\
\text { лимфоузлов }\end{array}$ & $\begin{array}{l}\text { Гипер -емия } \\
\text { и отечность } \\
\text { десны при- } \\
\text { чинного } \\
\text { зуба }\end{array}$ & $\begin{array}{c}\text { Перкуторная } \\
\text { реакция } \\
\text { причинного } \\
\text { зуба }\end{array}$ & $\begin{array}{c}\text { Наличие } \\
\text { экссудата } \\
\text { в каналах }\end{array}$ & \\
\hline \multirow[t]{2}{*}{16} & $10 /$ & абс. & 4 & 10 & 10 & 10 & 10 & \multirow[t]{2}{*}{5} \\
\hline & 10 & $\%$ & 40,00 & 100 & 100 & 100 & 100 & \\
\hline \multirow[t]{2}{*}{17} & $10 /$ & абс. & 4 & 10 & 10 & 10 & 10 & \multirow[t]{2}{*}{5} \\
\hline & 10 & $\%$ & 40,00 & 100 & 100 & 100 & 100 & \\
\hline \multirow[t]{2}{*}{18} & $10 /$ & абс. & 5 & 10 & 10 & 10 & 10 & \multirow[t]{2}{*}{5} \\
\hline & 10 & $\%$ & 50,00 & 100 & 100 & 100 & 100 & \\
\hline \multirow[t]{2}{*}{19} & $10 /$ & абс. & 4 & 10 & 10 & 10 & 10 & \multirow[t]{2}{*}{5} \\
\hline & 10 & $\%$ & 40,00 & 100 & 100 & 100 & 100 & \\
\hline \multirow[t]{2}{*}{20} & $10 /$ & абс. & 5 & 10 & 10 & 10 & 10 & \multirow[t]{2}{*}{5} \\
\hline & 10 & $\%$ & 50,00 & 100 & 100 & 100 & 100 & \\
\hline
\end{tabular}

В 19 подгруппе с ОХВГП все обследованные также предъявляли жалобы на постоянную ноющую, нарастающую боль в области причинного зуба, головную боль отмечали восемь из них, с повышением температуры тела было 4 пациента. Объективно у четырех обследованных отмечалась асимметрия лица, гиперемия, отек слизистой оболочки причинного зуба и резкая перкуссия установлены у всех больных, с увеличением и болезненностью регионарных лимфатических желез. 
Идентичная клиническая картина была у больных с ОХВГП в 20 подгруппе: постоянная ноющая нарастающая боль в области причинного зуба, боль при накусывании (у 10 больных), явления интоксикации с головной болью, повышением температуры и потерей трудоспособности установлены у пяти из них. Острые явления воспаления в виде асимметрии лица установлены у пяти больных. Резкая болезненная перкуторная реакция, гиперемия и отечность слизистой оболочки в области всех причинных зубов, у девяти из них - соседних зубов. При инструментальной обработке установлено у всех больных с ОХВГП наличие экссудата в корневых каналах.

На рентгенограммах при ОХВГП очаги деструкции костной ткани отграничены от здоровых тканей фиброзной капсулой. Губчатое вещество более плотное (остеосклероз), линия периодонта переходит в костный дефект. При обострении процесса ОХВГП исчезает четкость очертания очага деструкции и костных оболочек за счет инфильтрации костных структур экссудатом. Рентгенологически, согласно периапикальному индексу (PAI), деструктивные изменения костных структур периапикальной области при хронических гранулематозных периодонтитах оценивается пятью баллами.

\subsection{2. Ближайшие результаты лечения ОХВГП с использованием ультразвука (внутриканально) и поляризованного света «Bioptron» и без них}

В настоящей главе представлены результаты применения различных медикаментозных средств для обработки корневых каналов зубов с ОХВГП в сочетании с физическими факторами и сроки купирования воспалительного процесса (табл. 26 и 27). Интерпретация таблиц 27 и 28 (3-5 дней) свидетельствует о прекращении боли у пациентов 16 подгруппы в 60,00\% случаев под воздействием 0,2\% РХГ, уменьшилась асимметрия лица у 75,00\% больных, исчезла гиперемия и отечность десны в 40,00\% случаях, безболезненная перкуссия причинного зуба установлена у 40,00\% больных. 
Прекращение экссудации из корневых каналов установлено в трех случаях из 10.

Таблица 26

Динамика клинических признаков острого воспаления в периапикальных тканях под воздействием различных лечебных комплексов у больных с ОХВГП (четвертая группа)

\begin{tabular}{|c|c|c|c|c|c|c|c|c|c|c|}
\hline \multirow{4}{*}{ 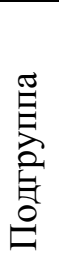 } & \multirow{4}{*}{$\begin{array}{l}\text { Комплекс } \\
\text { лечебных } \\
\text { воздействий }\end{array}$} & \multicolumn{9}{|c|}{ Купирование симптомов острого воспаления } \\
\hline & & \multicolumn{3}{|c|}{ Прекращение боли } & \multicolumn{3}{|c|}{$\begin{array}{l}\text { Уменьшение } \\
\text { асимметрии } \\
\text { лица }\end{array}$} & \multicolumn{3}{|c|}{$\begin{array}{c}\text { Исчезновение } \\
\text { гиперемии и } \\
\text { отечности десны }\end{array}$} \\
\hline & & \multirow[t]{2}{*}{ до } & \multicolumn{2}{|c|}{ после } & \multirow[t]{2}{*}{ до } & \multicolumn{2}{|c|}{ после } & \multirow[t]{2}{*}{ до } & \multicolumn{2}{|c|}{ после } \\
\hline & & & абс. & $\%$ & & aбc & $\%$ & & абс. & $\%$ \\
\hline 16 & $0,2 \% \mathrm{PX} \Gamma$ & 10 & 6 & 60,00 & 4 & 3 & 75,00 & 10 & 4 & 40,00 \\
\hline 17 & $0,2 \% \mathrm{PBC}$ & 10 & 7 & $\begin{array}{c}70,00 \\
p>0,05\end{array}$ & 4 & 3 & 75,00 & 10 & 6 & $\begin{array}{r}60,00 \\
p>0,05\end{array}$ \\
\hline 18 & $0,2 \% \mathrm{PBC}+\mathrm{Y} 3$ & 10 & 8 & $\begin{array}{c}80,00 \\
p>0,05\end{array}$ & 5 & 4 & $\begin{array}{c}80,00 \\
p>0,05\end{array}$ & 10 & 8 & $\begin{array}{c}80,00 \\
p>0,05\end{array}$ \\
\hline 19 & $0,2 \%$ РBC+УЗ+БТ & 10 & 10 & $\begin{array}{c}100 \\
p<0,05\end{array}$ & 4 & 4 & $\begin{array}{c}100 \\
p>0,05\end{array}$ & 10 & 10 & $\begin{array}{c}100 \\
\mathrm{p}<0,01\end{array}$ \\
\hline 20 & $0,2 \%$ РBC+УЗ+БТ & 10 & 10 & $\begin{array}{c}100 \\
p<0,05\end{array}$ & 5 & 5 & $\begin{array}{c}100 \\
p>0,05\end{array}$ & $\overline{10}$ & 10 & $\begin{array}{c}100 \\
\mathrm{p}<0,01\end{array}$ \\
\hline
\end{tabular}

Примечание: $\mathrm{p}$ - достоверность различий по отношению к 16 подгруппе

В 17 подгруппе под воздействием 0,2\% РВС боли купировались в 70,00\% случаев; асимметрия лица уменьшилась в $75,00 \%$ случаев; исчезла гиперемия лица, отек десны у 60,00\% больных; прекратилась экссудация из корневых каналов и определилась безболезненная перкуссия причинного зуба также в $60,00 \%$ случаев, соседних зубов - у 75,00\% пациентов.

Таблица 27

Изменение клинических признаков острого воспаления в периапикальных тканях под воздействием различных лечебных комплексов у больных с ОХВГП (четвертая группа)

\begin{tabular}{|c|c|c|c|c|c|c|c|}
\hline \multirow{4}{*}{$\begin{array}{l}\text { Под- } \\
\text { группа }\end{array}$} & \multirow{4}{*}{$\begin{array}{l}\text { Комплекс } \\
\text { лечебных } \\
\text { воздействий }\end{array}$} & \multicolumn{6}{|c|}{ Купирование симптомов острого воспаления } \\
\hline & & \multicolumn{3}{|c|}{$\begin{array}{c}\text { Болезненная перкуссия } \\
\text { причинного зуба }\end{array}$} & \multicolumn{3}{|c|}{$\begin{array}{c}\text { Прекращения явлений } \\
\text { экссудации }\end{array}$} \\
\hline & & \multirow[t]{2}{*}{ до } & \multicolumn{2}{|c|}{ после } & \multirow[t]{2}{*}{ до } & \multicolumn{2}{|c|}{ после } \\
\hline & & & абс. & $\%$ & & абс. & $\%$ \\
\hline 16 & $0,2 \% \mathrm{PX} \Gamma$ & 10 & 4 & 40,00 & 10 & 3 & 30,00 \\
\hline 17 & $0,2 \% \mathrm{PBC}$ & 10 & 6 & $\begin{array}{c}60,00 \\
p>0,05\end{array}$ & 10 & 6 & $\begin{array}{c}60,00 \\
p>0,05\end{array}$ \\
\hline 18 & $0,2 \% \mathrm{PBC}+\mathrm{Y3}$ & 10 & 7 & $\begin{array}{c}70,00 \\
p>0,05\end{array}$ & 10 & 8 & $\begin{array}{c}80,00 \\
\mathrm{p}<0,02\end{array}$ \\
\hline 19 & $0,2 \%$ РBC+УЗ+БТ & 10 & 10 & $\begin{array}{c}100 \\
p<0,01\end{array}$ & 10 & 10 & $\begin{array}{c}100 \\
p<0,01\end{array}$ \\
\hline 20 & $0,2 \% \mathrm{PBC}+\mathrm{Y3}+\mathrm{БT}$ & 10 & 10 & $\begin{array}{c}100 \\
p<0,01\end{array}$ & 10 & 10 & $\begin{array}{c}100 \\
p<0,01\end{array}$ \\
\hline
\end{tabular}

Примечание: $\mathrm{p}$ - достоверность различий по отношению к 16 подгруппе 
В 18 подгруппе, где для медикаментозной обработки корневых каналов использовался озвученный $0,2 \%$ РВС, боли купировались в $80,00 \%$ случаев, безболезненная перкуторная реакция причинного зуба установлена в 70,00\% случаев, соседних зубов - в четырех $(80,00 \%)$ из пяти до лечения, с уменьшением асимметрии лица, гиперемии и отечности слизистой оболочки причинного зуба, прекращением явлений экссудации из корневых каналов.

В 19 и 20 подгруппах, где применялись традиционный и отсроченный методы, для санации корневой системы применялся озвученный велтосепт в сочетании с биостимулирующим светом «Bioptron». Под воздействием данного комплекса все симптомы острых явлений в периодонте были купированы в 100\% случаев в течение 3-5 дней. Таким образом, наилучшие показатели зарегистрированы в тех подгруппах $(19,20)$, где применялся в комплексе лечебных воздействий свет «Bioptron».

4.4.3. Сравнительная оценка эффективности воздействия на периодонт при ОХВГП различных пломбировочных материалов

Анализ ближайших осложнений, связанных с пломбированием системы корневых каналов после купирования острых явлений в периодонте у пациентов с ОХВГП, представлен в таблице 28 и 29. После пломбирования корневых каналов зубов у больных с ОХВГП в 16 подгруппе установлено наибольшее количество осложнений 90,00\% случаев.

Таблица 28

Лечебные комплексы воздействия у пациентов с ОХВГП (четвертая группа)

\begin{tabular}{|c|c|c|c|c|c|}
\hline \multirow{2}{*}{$\begin{array}{l}\text { Под } \\
\text { груп } \\
\text { па }\end{array}$} & \multirow{2}{*}{$\begin{array}{l}\text { Кол- } \\
\text { во } \\
\text { зубов }\end{array}$} & \multirow[t]{2}{*}{ Метод } & \multicolumn{3}{|c|}{ Комплекс лечебных воздействий } \\
\hline & & & $\begin{array}{l}\text { Медикамен- } \\
\text { тозное }\end{array}$ & Физическое & Пломбировочный материал \\
\hline 16 & 10 & $\mathrm{TP}$ & $0,2 \%$ РХГ & - & ЭВ \\
\hline 17 & 10 & $\mathrm{TP}$ & $2 \% \mathrm{PBC}$ & - & ВСП № 1 \\
\hline 18 & 10 & TP & $0,2 \% \mathrm{PBC}$ & У3 & ВСП №1+ГШ \\
\hline 19 & 10 & TP & $0,2 \% \mathrm{PBC}$ & УЗ+БТ & ВСПОИ № $2+$ ГШ \\
\hline 20 & 10 & OT & $0,2 \% \mathrm{PBC}$ & УЗ+БТ & ОТ-«Кальсепт» + ВСПОИ №2 + \\
\hline
\end{tabular}

На вторые сутки после пломбирования больные жаловались на постоянную ноющую боль, боль при накусывании на причинный зуб. При 
осмотре отмечалась гиперемия, отек десны и болезненная перкуторная реакция причинного зуба, у пяти из них переходная складка была сглажена и отмечалась незначительная асимметрия лица. В 17 подгруппе с ОХВГП после пломбирования корневых каналов ВСП № 1 в комплексе с санацией корневой системы 0,2\% РВС осложнения возникли в 50,00\% случаев, которые выражались в болезненности при перкуссии на причинный зуб. При осмотре была установлена гиперемия и отечность десны и болезненная перкуторная реакция, а в двух случаях - сглаженность переходной складки. В 18 подгруппе корневые каналы пломбировались также ВСП № 1 с гуттаперчевыми штифтами, но предварительно корневые каналы зубов обрабатывались не только 0,2\% PBC, но и ультразвуком аппарата «Amdent US 30 D» внутриканально. Постпломбировочные боли возникли у двух пациентов $(20,00 \%)$ с явлениями ноющей боли при накусывании и перкусии, незначительной гиперемии слизистой оболочки в области причинных зубов.

Таблица 29

Клинические данные после пломбирования корневых каналов у пациентов с ОХВГП различными эндодонтическими пломбировочными материалами (четвертая группа)

\begin{tabular}{|c|c|c|c|c|c|c|c|c|c|c|}
\hline \multirow{3}{*}{ 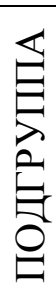 } & \multirow{3}{*}{$\begin{array}{l}\text { Кол- } \\
\text { во } \\
\text { зу- } \\
\text { бов }\end{array}$} & \multirow{3}{*}{\begin{tabular}{|l}
$\mathrm{M}$ \\
$\mathrm{E}$ \\
$\mathrm{T}$ \\
$\mathrm{O}$ \\
Д
\end{tabular}} & \multirow{2}{*}{\multicolumn{2}{|c|}{$\begin{array}{c}\text { Осложнения } \\
\text { после } \\
\text { пломбирования }\end{array}$}} & \multicolumn{6}{|c|}{ Клинические симптомы } \\
\hline & & & & & \multicolumn{2}{|c|}{$\begin{array}{c}\text { Боль при } \\
\text { перкуссии и } \\
\text { накусывании на } \\
\text { причинный зуб }\end{array}$} & \multicolumn{2}{|c|}{$\begin{array}{c}\text { Гиперемия, отек } \\
\text { мягких тканей }\end{array}$} & \multicolumn{2}{|c|}{$\begin{array}{c}\text { Сглаженность } \\
\text { переходной } \\
\text { складки }\end{array}$} \\
\hline & & & абс & $\%$ & aбc & $\%$ & абс & $\%$ & абс & $\%$ \\
\hline 16 & 10 & $\mathrm{TP}$ & 9 & 90,00 & 9 & 90,00 & 9 & 90,00 & 5 & 50,00 \\
\hline 17 & 10 & $\mathrm{TP}$ & 5 & $\begin{array}{c}50,00 \\
p>0,05\end{array}$ & 5 & $\begin{array}{c}50,00 \\
p>0,05\end{array}$ & 5 & $\begin{array}{c}50,00 \\
p>0,05\end{array}$ & 2 & $\begin{array}{c}20,00 \\
p>0,05\end{array}$ \\
\hline 18 & 10 & ТP & 2 & $\begin{array}{c}20,00 \\
\mathrm{p}<0,01\end{array}$ & 2 & $\begin{array}{c}20,00 \\
\mathrm{p}<0,01\end{array}$ & 2 & $\begin{array}{c}20,00 \\
\mathrm{p}<0,01\end{array}$ & 0 & $\begin{array}{c}0,00 \\
\mathrm{p}<0,01\end{array}$ \\
\hline 19 & 10 & $\mathrm{TP}$ & 0 & $\begin{array}{c}0,00 \\
\mathrm{p}<0,01\end{array}$ & 0 & $\begin{array}{c}0,00 \\
p<0,01\end{array}$ & 0 & $\begin{array}{c}0,00 \\
\mathrm{p}<0,01\end{array}$ & 0 & $\begin{array}{c}0,00 \\
p<0,01\end{array}$ \\
\hline 20 & 10 & OT & 0 & $\begin{array}{c}0,00 \\
p<0,01\end{array}$ & 0 & $\begin{array}{c}0,00 \\
p<0,01\end{array}$ & 0 & $\begin{array}{c}0,00 \\
p<0,01\end{array}$ & 0 & $\begin{array}{c}0,00 \\
\mathrm{p}<0,01\end{array}$ \\
\hline
\end{tabular}

Примечание: $\mathrm{p}$ - достоверность различий по отношению к 16 подгруппе

В подгруппе 19 корневые каналы пломбировались ВСПОИ № 2 с гуттаперчевыми штифтами. Санация корневых каналов осуществлялась 0,2\% PBC с последующей обработкой ультразвуком внутриканально. Лечение 
ОХВГП в данной подгруппе проводилось традиционным методом. До и после окончания лечения на область пломбированного зуба воздействовали в течение 10 минут (2-3 сеанса) полихроматичным светом «Bioptron». Этот комплекс лечебных воздействий при лечении гранулематозных периодонтитов позволил предупредить возникновение постпломбировочного обострения в периодонте. В 20 подгруппе изучался отсроченный метод лечения. Для временного пломбирования корневых каналов применялся материал «Кальсепт», которым заполнялись корневые каналы на 1 месяц, после чего временный материал удалялся и каналы пломбировались ВСПОИ № 2. Санация корневых каналов осуществлялась идентично как в 19 подгруппе. Также после постоянного пломбирования корневых каналов применялся биостимулирующий БТ чрезкожно.
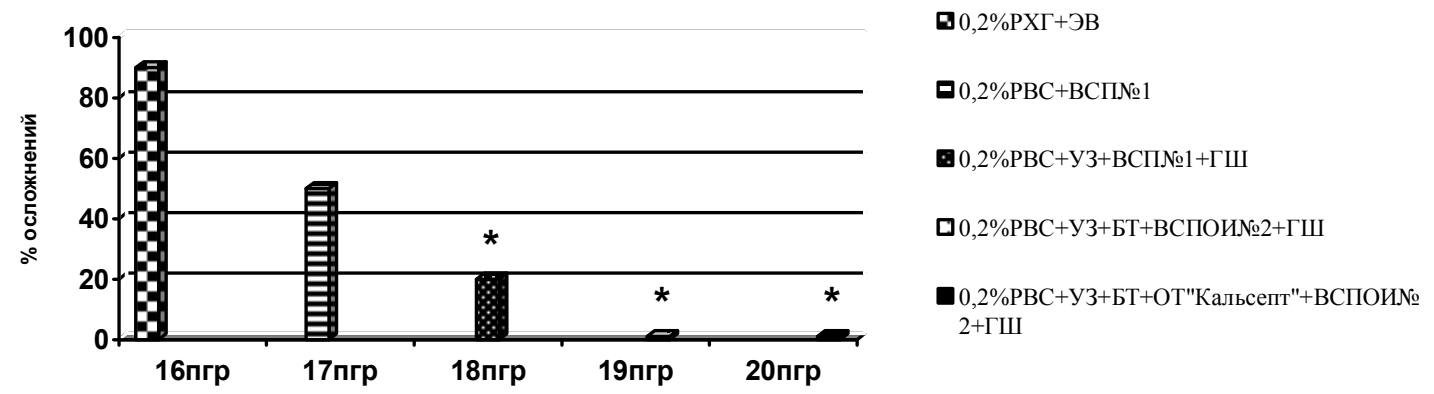

Примечание: *p<0,01 по отношению к 16-ой подгруппе

\section{Рис.11. Сравнительная характеристика осложнений после лечения ОХВГП различными лечебными комплексами (четвертая группа)}

Осложнений после применения отсроченного метода лечения ОХВГП данным лечебным комплексом не зарегистрировано. Сравнивая процент осложнений после пломбирования корневых каналов зубов необходимо отметить, что лучшим пломбировочным материалом была предложенная нами ВСПОИ № 2, как в 19 (ТР), так и в 20 (ОТ) подгруппах в комплексе с БТ, свидетельствуя о положительном влиянии данных лечебных комплексов на патологический очаг воспаления в периодонте в ближайшие сроки наблюдений (рис.11). 

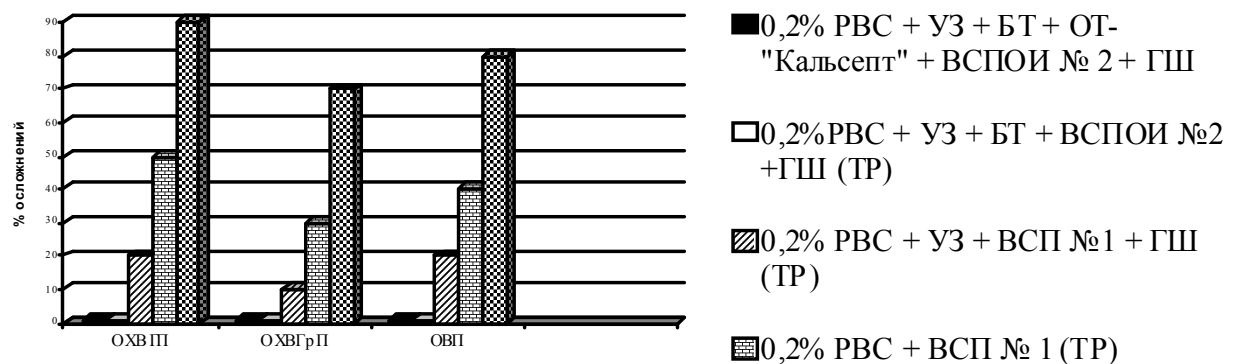

Рис.12 Зависимость частоты осложнений от формы периодонтита и эндодонтического материала в ближайшие сроки после пломбирования корневых каналов зубов

Итак, сравнивая эффективность различных комплексов при лечении ОВП и ОХВП в ближайшие сроки наблюдений, можно с уверенностью констатировать, что лучшие результаты были достигнуты в подгруппах 4, 5 , $9,10,14,15,19,20$, где корневые каналы пломбировались ВСПОИ №2 в комплексе с санацией системы каналов озвученным РВС и БТ для купирования острых явлений воспаления, как ТР, так и ОТ методами (рис.12).

4.5. Изучение цитохимических показателей у больных с различными формами периодонтитов до и после воздействия комплексной терапии с применением света «Bioptron»

Исследование иммунного статуса было проведено у больных верхушечными периодонтитами в острой и обострившейся хронических стадиях течения инфекционного процесса. При этом проводилась оценка показателей клеточного состава и активности микробицидных систем нейтрофилов содержимого десневого желобка, которое включало определение местного иммунитета отдельного зубочелюстного сегмента до лечения, на следующий день после пломбирования каналов, через 15 и 30 суток после лечения.

\subsection{1. Клеточный состав содержимого десневого желобка до и после лечения острых верхушечных периодонтитов}

В экспериментальную группу были включены 10 больных с острыми периодонтитами с различной локализацией патологического процесса и 
степенью его выраженности. Забор материала из зубодесневого желобка для исследования осуществляли в области пораженного и симметричного ему здорового зуба до лечения, через сутки, 15 и 30 суток после терапии. Определяли клеточный состав данного материала, проводя сравнение вычисленных параметров в области больного зуба с индивидуальной нормой пациента.

Таблица 30

Клеточный состав десневого желобка до и после лечения у больных с острыми апикальными периодонтитами

\begin{tabular}{|l|c|l|l|l|}
\hline & \multirow{2}{*}{$\begin{array}{l}\text { Количество } \\
\text { больных }\end{array}$} & \multicolumn{3}{|c|}{ Усредненные показатели клеточного состава } \\
\cline { 3 - 5 } & & $\begin{array}{l}\text { эпителиальные } \\
\text { клетки }\end{array}$ & \multicolumn{1}{|c|}{ нейтрофилы } & лимфоциты \\
\hline $\begin{array}{l}\text { 3доровая сторона } \\
\text { (индивидуальная } \\
\text { норма) }\end{array}$ & 10 & $34,00 \pm 0,30$ & $54,60 \pm 0,30$ & $11,30 \pm 0,10$ \\
\hline $\begin{array}{l}\text { Больная сторона } \\
\text { (до лечения) }\end{array}$ & 10 & $\begin{array}{l}17,00 \pm 0,80 \\
\mathrm{p}<0,01\end{array}$ & $\begin{array}{l}76,30 \pm 0,70 \\
\mathrm{p}<0,01\end{array}$ & $\begin{array}{l}6,60 \pm 0,10 \\
\mathrm{p}<0,01\end{array}$ \\
\hline $\begin{array}{l}\text { Больная сторона } \\
\text { (после лечения) }\end{array}$ & 10 & $\begin{array}{l}27,60 \pm 0,70 \\
\mathrm{p}<0,01 \\
\mathrm{p} 1<0,01\end{array}$ & $\begin{array}{l}63,00 \pm 0,60 \\
\mathrm{p}<0,01\end{array}$ & $\begin{array}{l}9,30 \pm 0,80 \\
\mathrm{p}<0,01 \\
\mathrm{p} 1<0,01\end{array}$ \\
\hline Через 30 суток & 10 & $\begin{array}{l}33,00 \pm 0,20 \\
\mathrm{p}<0,01\end{array}$ & $\begin{array}{l}53,80 \pm 0,20 \\
\mathrm{p}<0,02\end{array}$ \\
$\mathrm{p} 1<0,01$ & $\begin{array}{l}11,00 \pm 0,10 \\
\mathrm{p}<0,02 \\
\mathrm{p} 1<0,01\end{array}$ \\
\hline
\end{tabular}

Примечание: $\mathrm{p}$ - достоверность по отношению к индивидуальной норме, $\mathrm{p} 1$ - по отношению к показателям до лечения

Контролем для данной группы пациентов, как и в дальнейших наблюдениях, являлась индивидуальная норма пациента, которая характеризовалась оцениваемыми показателями в материале, забираемом из симметричного участка десневого желобка противоположной (здоровой) стороны челюсти. Клеточный состав десневого желобка ОВП представлен в таблице 30 и рисунке 13.

Анализ полученных данных показал, что в результате развития острого патологического процесса клеточный состав содержимого десневого желобка резко изменяется, что характеризовалось значительным достоверным увеличением $(76,3 \pm 0,7 \%)$ содержания $\mathrm{H}$ относительно индивидуальной нормы $(54,6 \pm 0,3 \%)$ данного показателя. В то же время отмечалось снижение 
определяемого количества ЭК до $17,0 \pm 0,8 \%$ и Л до $6,6 \pm 0,10 \%$, при индивидуальной норме $34,0 \pm 0,3 \%$ и $11,3 \pm 0,1 \%$ соответственно (рис.13).

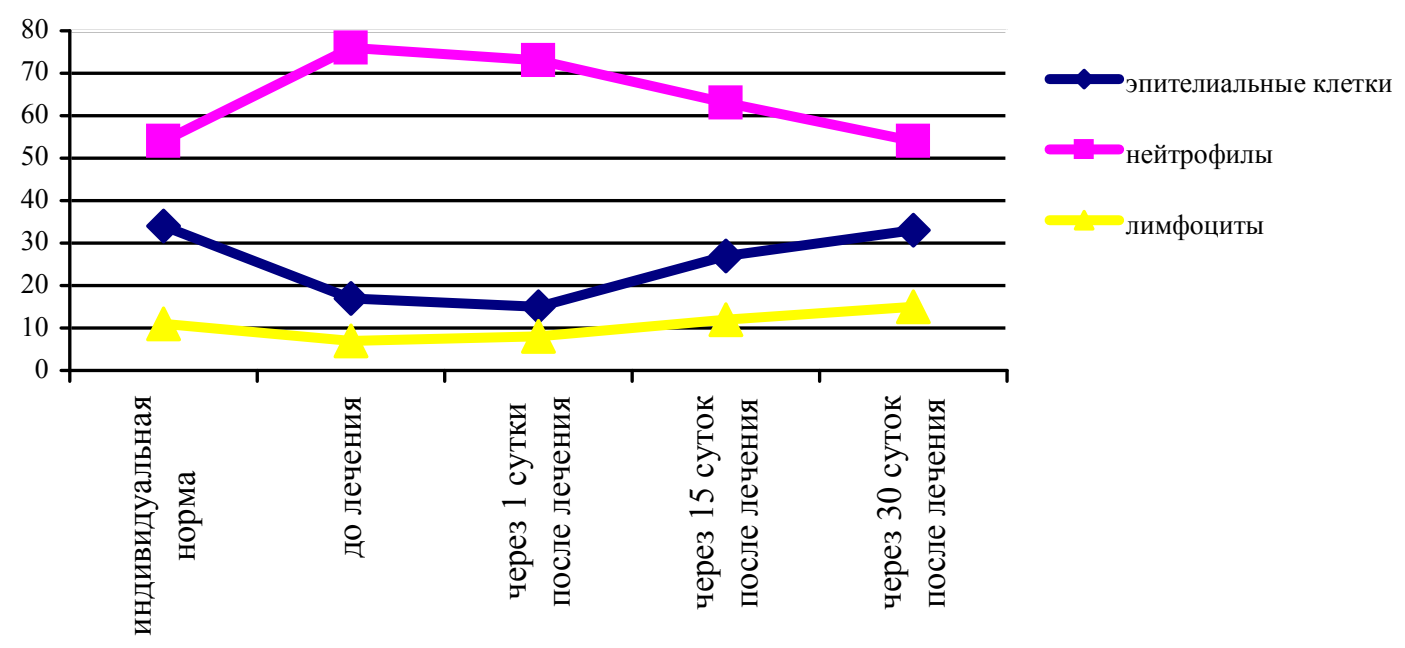

Рис.13 Клеточный состав десневого желобка с ОВП

В результате проводимой комплексной терапии (велтосепт+УЗ+БТ+ВСПОИ№2) наблюдалась достоверная тенденция изменения вычисляемых показателей в течение срока наблюдения (30 суток), которая проявлялась восстановлением измененных соотношений состава клеточных показателей к уровню индивидуальной нормы. Таким образом, проводимая комплексная терапия оказывала положительное влияние на состояние местного иммунитета, который оценивался по соотношению клеточных элементов (Н - Л - ЭК) содержимого десневого желобка.

\subsection{2. Изучение активности ферментативных систем нейтрофилов у больных с острыми верхушечными периодонтитами}

Большое значение в проявлении защитных функций нейтрофилов имеют их ферментные системы, такие как миелопероксидаза, лизосомальные катионные белки, кислая и щелочная фосфатаза.

Миелопероксидаза (МПО) - катионный, содержащий железо фермент, обладающий бактерицидными свойствами. Она защищает организм от действия бактериальных токсинов, грибов, вирусов, микоплазм. Недостаточность МПО может иметь наследственный характер или выявляться при ряде заболеваний (в частности, инфекционных, вирусных и 
т.д.). Развитие острой формы периодонтита сопровождалось снижением активности МПО до $0,95 \pm 0,01 \%$ в сравнении с индивидуальной нормой $(1,55 \pm 0,01 \%)$ (табл. 31$)$.

Катионные белки (КБ) важнейший кислороднезависимый компонент микробицидной системы лейкоцитов. КБ находятся только в лизосомах лейкоцитов, их нет в лизосомах других клеток. Известна способность КБ подавлять активность различных видов грамотрицательных и грамположительных микробов. Связываясь с отрицательно заряженными компонентами микробной клетки, КБ нарушают жизненно важные процессы ионной проницаемости, энергетики и размножения микробов. В эксперименте у больных с острыми верхушечными периодонтитами зарегистрировано снижение количества КБ $(1,04 \pm 0,01 \%)$ в сравнении с индивиуальной нормой $(1,42 \pm 0,01 \%)$.

Таблица 31

Усредненные цитоэнзимохимические показатели нейтрофилов в различные сроки лечения у больных с ОВП

\begin{tabular}{|c|c|c|c|c|c|}
\hline \multirow[b]{2}{*}{ Ферменты } & \multicolumn{5}{|c|}{$\begin{array}{l}\text { Цитоэнзимохимические показатели нейтрофилов (в \%) в зависимости от } \\
\text { сроков лечения }(\mathrm{M} \pm \mathrm{m}) \text { : }\end{array}$} \\
\hline & $\begin{array}{l}\text { Индиви- } \\
\text { дуальная } \\
\text { норма } \\
\end{array}$ & До лечения & $\begin{array}{l}\text { Через сутки } \\
\text { после } \\
\text { лечения }\end{array}$ & $\begin{array}{lr}\text { Через } & 15 \\
\text { суток после } \\
\text { лечения }\end{array}$ & $\begin{array}{l}\text { Через } 30 \\
\text { суток после } \\
\text { лечения }\end{array}$ \\
\hline МПО & $1,55 \pm 0,01$ & $\begin{array}{l}0,95 \pm 0,01 \\
\mathrm{p}<0,01\end{array}$ & $\begin{array}{l}1,04 \pm 0,02 \\
\text { p }<0,01 \\
\text { p } 1<0,01\end{array}$ & $\begin{array}{l}1,42 \pm 0,01 \\
\mathrm{p}<0,01 \\
\mathrm{p} 1<0,01\end{array}$ & $\begin{array}{l}1,53 \pm 0,01 \\
p>0,1 \\
p 1<0,01\end{array}$ \\
\hline КБ & $1,42 \pm 0,01$ & $\begin{array}{l}1,04 \pm 0,01 \\
\mathrm{p}<0,01\end{array}$ & $\begin{array}{l}1,16 \pm 0,03 \\
\text { p }<0,01 \\
\text { p1<0,01 }\end{array}$ & $\begin{array}{l}1,30 \pm 0,02 \\
\text { p }<0,01 \\
\text { p } 1<0,01\end{array}$ & $\begin{array}{l}1,40 \pm 0,01 \\
p>0,1 \\
p 1<0,01\end{array}$ \\
\hline ЩФ & $1,92 \pm 0,01$ & $\begin{array}{l}2,43 \pm 0,01 \\
\mathrm{p}<0,01\end{array}$ & $\begin{array}{l}2,04 \pm 0,01 \\
\text { p }<0,01 \\
\text { p1 }<0,01\end{array}$ & $\begin{array}{l}2,00 \pm 0,02 \\
\text { p }<0,01 \\
\text { p } 1<0,01\end{array}$ & $\begin{array}{l}1,90 \pm 0,01 \\
p>0,1 \\
\text { p } 1<0,01\end{array}$ \\
\hline КФ & $1,45 \pm 0,01$ & $\begin{array}{l}2,08 \pm 0,01 \\
\mathrm{p}<0,01\end{array}$ & $\begin{array}{l}1,96 \pm 0,02 \\
p<0,01 \\
\text { p } 1<0,01\end{array}$ & $\begin{array}{l}1,75 \pm 0,02 \\
\text { p }<0,05 \\
\text { p } 1<0,01\end{array}$ & $\begin{array}{l}1,47 \pm 0,01 \\
p>0,1 \\
\text { p } 1<0,01\end{array}$ \\
\hline
\end{tabular}

Примечание: $\mathrm{p}$ - достоверность по отношению к индивидуальной норме, p1 - по отношению к показателям до лечения

Щелочная фосфатаза играет значительную роль в интралейкоцитарной бактерицидной функции нейтрофилов. Считается, что ЩФ регулирует хаотическое и направленное движение последних, поглощение 
фагоцитируемых частиц, переход гранулярных ферментов первичных гранул и фагоцитарные вакуоли, высвобождение гистамина под влиянием антигенов и целый ряд других метаболических процессов. Отмечено, что в процессе фагоцитоза наиболее активное поглощение бактерий происходит с высокой активностью ЩФ. Определенное значение в защитных реакциях имеет КФ. Она участвует в процессах переваривания бактерий, умерщвленных в результате воздействия КБ и МПО. Она подвергает гидролизу в кислой среде бактерий, разрушая мукопептидные структуры, составляющие каркас большинства бактериальных клеток.

У больных с острыми формами верхушечных периодонтитов установлено увеличение активности щелочной и кислой фосфатаз, составляя $2,43 \pm 0,01 \%$ и $2,08 \pm 0,01 \%$ в сравнении с индивидуальной нормой $1,92 \pm 0,01 \%$ и $1,45 \pm 0,01 \%$ соответственно.

Изменение содержания ферментов и КБ в нейтрофилах связано с активной фагоцитарной деятельностью последних, вызывающих острый инфекционный процесс. Через сутки после проведенной терапии комплексом: велтосепт+УЗ+БТ+ВСПОИ№2, показатели активности КФ и ЩФ заметно снизились, а активность МПО и содержание в нейтрофилах КБ возросли.

На 15 сутки наблюдения количественные значения всех изучаемых цитоэнзимохимических маркеров еще более приблизились к индивидуальной норме, а к 30 суткам после лечения показатели активности МПО, КФ, ЩФ $(1,53 \pm 0,01 \% ; 1,47 \pm 0,01 \% ; 1,90 \pm 0,01 \%)$ и количество КБ $(1,40 \pm 0,01 \%)$ в нейтрофилах периферической крови соответствовали данным, характеризующим индивидуальную норму пациентов.

Таким образом, развитие острых верхушечных периодонтитов влияет на показатели состояния местного иммунитета, о чем свидетельствует как изменение клеточного состава содержимого десневого желобка за счет значительного увеличения количества нейтрофилов и снижения лимфоцитов и эпителиальных клеток, так и цитоэнзимохимических показателей 
нейтрофилов. Проводимое комплексное лечение предложенным комплексом, вызывая положительный терапевтический эффект, стимулирует процесс нормализации показателей состояния местного иммунитета зубодесневого сегмента, о чем свидетельствует восстановление показателей активности ферментных систем нейтрофилов и клеточного состава содержимого десневого желобка.

4.5.3. Клеточный состав содержимого десневого желобка до и после лечения у больных с различными формами обострившихся хронических верхушечных периодонтитов

В связи с разрабатываемым способом лечения верхушечных периодонтитов у больных с обострившимся хроническим течением данного заболевания представляло интерес изучение состояния местного иммунитета у больных до лечения и влияние на него комплекса проводимой терапии. Изучение клеточного состава десневого желобка было проведено на группе больных (20 человек) с различными клиническими формами заболевания, которые были представлены подгруппами (по 10 человек каждая) с обострившимися гранулирующим, гранулематозным периодонтитом по вышеуказанной методике (табл. 32). В результате анализа полученных данных было установлено, что до лечения во всех группах наблюдаемых больных отмечалось достоверное снижение показателей эпителиальных клеток относительно индивидуальной нормы. Так, средние значения этого

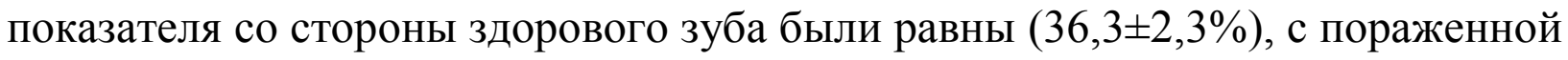
стороны, до лечения, независимо от вида хронических периодонтитов $27,0 \pm 2,3 \%$. Противоположная закономерность была установлена для нейтрофилов, как основных клеток, участвующих в процессе фагоцитоза и обеспечивающих формирование воспалительной реакции. До лечения средние значения показателя у больных составляли $57,9 \pm 0,6 \%$, при средней

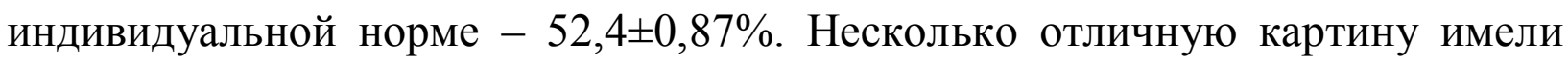
показатели лимфоцитов содержимого десневого желобка. Так, если средняя индивидуальная норма выражалась значением $11,3 \pm 1,3 \%$, то в случае 
гранулирующего и гранулематозного периодонтитах - был выше нормы, составляя соответственно $(17,8 \pm 1,9 \%$ и $16,4 \pm 1,6 \%)$.

Таблица 32

Клеточный состав содержимого десневого желобка у больных с различными формами обострившихся верхушечных периодонтитов

\begin{tabular}{|c|c|c|c|c|c|}
\hline \multirow{2}{*}{$\begin{array}{c}\text { Формы хронических } \\
\text { верхушечных } \\
\text { периодонтитов }\end{array}$} & \multirow{2}{*}{ 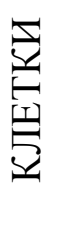 } & \multicolumn{4}{|c|}{$\begin{array}{c}\text { Показатели клеточного состава (в \%) в содержимом } \\
\text { десневого желобка в зависимости от сроков лечения }(\mathrm{M} \pm \mathrm{m})\end{array}$} \\
\hline & & До лечения & $\begin{array}{c}\text { Через сутки } \\
\text { после } \\
\text { лечения }\end{array}$ & $\begin{array}{c}\text { Через } 30 \\
\text { суток после } \\
\text { лечения }\end{array}$ & $\begin{array}{c}\text { Индивидуальная } \\
\text { норма }\end{array}$ \\
\hline \multirow[t]{3}{*}{ Гранулирующий } & ЭК & $\begin{array}{c}26,30 \pm 2,20 \\
\mathrm{p}<0,01\end{array}$ & $\begin{array}{c}30,50 \pm 2,30 \\
\mathrm{p}<0,05 \\
\mathrm{p} 1>0,1\end{array}$ & $\begin{array}{c}34,60 \pm 1,20 \\
\mathrm{p}>0,1 \\
\mathrm{p} 1<0,01\end{array}$ & $35,50 \pm 1,70$ \\
\hline & $\mathrm{H}$ & $\begin{array}{l}55,90 \pm 0,50 \\
\mathrm{p}<0,02\end{array}$ & $\begin{array}{c}55,30 \pm 1,10 \\
\mathrm{p}>0,1 \\
\mathrm{p} 1>0,1\end{array}$ & $\begin{array}{c}53,30 \pm 0,90 \\
p>0,1 \\
p 1<0,01\end{array}$ & $53,50 \pm 1,10$ \\
\hline & Л & $\begin{array}{l}17,80 \pm 1,90 \\
\mathrm{p}<0,01\end{array}$ & $\begin{array}{l}14,20 \pm 1,20 \\
\text { p }<0,02 \\
\text { p1 }>0,1\end{array}$ & $\begin{array}{c}12,10 \pm 2,50 \\
p>0,1 \\
p 1<0,05\end{array}$ & $11,00 \pm 0,90$ \\
\hline \multirow[t]{3}{*}{ Гранулематозный } & ЭК & $\begin{array}{c}28,00 \pm 2,10 \\
\mathrm{p}<0,01\end{array}$ & $\begin{array}{c}31,60 \pm 1,80 \\
\mathrm{p}>0,1 \\
\mathrm{p} 1>0,1\end{array}$ & $\begin{array}{c}36,80 \pm 1,10 \\
\mathrm{p}>0,1 \\
\mathrm{p} 1<0,01\end{array}$ & $36,00 \pm 2,10$ \\
\hline & $\mathrm{H}$ & $\begin{array}{c}55,60 \pm 0,80 \\
p<0,01\end{array}$ & $\begin{array}{c}55,00 \pm 1,40 \\
\mathrm{p}<0,05 \\
\mathrm{p} 1>0,1\end{array}$ & $\begin{array}{c}52,10 \pm 0,70 \\
p>0,1 \\
p 1<0,01\end{array}$ & $51,90 \pm 0,80$ \\
\hline & Л & $\begin{array}{l}16,40 \pm 1,60 \\
p<0,05\end{array}$ & $\begin{array}{c}13,40 \pm 1,80 \\
\mathrm{p}>0,1 \\
\mathrm{p} 1>0,1\end{array}$ & $\begin{array}{c}11,10 \pm 2,30 \\
\mathrm{p}>0,1 \\
\mathrm{p} 1<0,05\end{array}$ & $12,10 \pm 1,80$ \\
\hline \multirow[t]{3}{*}{$(\mathrm{M} \pm \mathrm{m})$} & ЭК & $\begin{array}{l}27,00 \pm 2,30 \\
\mathrm{p}<0,01\end{array}$ & $\begin{array}{c}30,30 \pm 2,06 \\
\text { p }<0,05 \\
\text { p1 }>0,1\end{array}$ & $\begin{array}{c}34,10 \pm 1,30 \\
\mathrm{p}>0,1 \\
\mathrm{p} 1<0,01\end{array}$ & $36,30 \pm 2,30$ \\
\hline & $\mathrm{H}$ & $\begin{array}{l}57,90 \pm 0,60 \\
\mathrm{p}<0,01\end{array}$ & $\begin{array}{c}56,50 \pm 1,10 \\
\text { p }<0,01 \\
\text { p1 }>0,1\end{array}$ & $\begin{array}{c}54,80 \pm 0,70 \\
\mathrm{p}<0,02 \\
\mathrm{p} 1<0,01\end{array}$ & $52,40 \pm 0,87$ \\
\hline & Л & $\begin{array}{c}15,10 \pm 1,50 \\
p<0,05\end{array}$ & $\begin{array}{c}13,10 \pm 1,60 \\
\mathrm{p}>0,1 \\
\mathrm{p} 1>0,1\end{array}$ & $\begin{array}{c}11,07 \pm 2,27 \\
p>0,1 \\
p 1>0,1\end{array}$ & $11,30 \pm 1,30$ \\
\hline
\end{tabular}

Примечание: p - достоверность по отношению к индивидуальной норме, p1 - по отношению к показателям до лечения

Полученная картина состава клеточного содержимого десневого желобка до лечения соответствовала картине развившегося воспалительного процесса в области тканей корня зуба, что на местном уровне проявлялось увеличением количества клеток, обладающих фагоцитарной активностью (нейтрофилов), выраженным снижением количества нормальных клеточных 
элементов содержимого десневого желобка (эпителиальных клеток) и увеличением количества лимфоцитов, как участников процесса специфической иммунной реакции.

Под влиянием медикаментозного и физического (света Bioptron» и ультразвука) воздействия у всех наблюдаемых групп больных произошло восстановление оцениваемых показателей до уровня индивидуальной нормы, что свидетельствовало о стихании воспалительного процесса. Следует отметить, что динамика изменений клеточного состава десневого желобка под воздействием проводимой терапии, указывало на положительный терапевтический эффект.

4.5.4. Изучение активности цитоэнзимохимических показателей нейтрофилов у больных с различными формами обострившихся хронических верхушечных периодонтитов

Большое значение в проявлении защитных функций фагоцитов имеют их ферментные системы, такие как миелопероксидаза, лизосомальные катионные белки, кислая и щелочная фосфатазы. Нами была изучена активность четырех вышеописанных ферментов (табл. 33) у больных различными формами ОХВП. Исследования показали, что развитие обострения хронических верхушечных периодонтитов сопровождается изменениями всех изучаемых цитоэнзимохимических маркеров с теми же тенденциями, что и для острого процесса данного заболевания. При обострившихся гранулирующих и гранулематозных периодонтитах происходило более выраженное снижение активности МПО, содержания КБ и увеличение показателей ферментативной активности КФ и ЩФ. Следует отметить, что по количественным показателям цитоэнзимохимических маркеров эти формы периодонтита были приблизительно равноценны. Уже через сутки после проведенного лечения происходило заметное изменение в сторону усредненной нормы активности МПО, ЩФ, КФ и содержания КБ. На 15 сутки наблюдали более интенсивное восстановление величины всех цитоэнзимохимических показателей нейтрофилов периферической крови, 
которые, однако, все еще отставали от показателей индивидуальной нормы пациентов. Изучение маркеров на 30 сутки после воздействия терапии предлагаемого нами комплекса (велтосепт+УЗ+БТ+ВСПОИ) показало, что все они полностью восстановились, о чем свидетельствовала их идентичность с показателями крови из десны симметричного зуба здоровой стороны челюсти пациентов.

Таблица 33

\section{Цитоэнзимохимические показатели нейтрофилов периферической} крови больных в различные сроки лечения ОХВП

\begin{tabular}{|c|c|c|c|c|c|c|}
\hline \multirow{2}{*}{$\begin{array}{l}\text { Формы } \\
\text { хронического } \\
\text { верхушечного } \\
\text { периодонтита }\end{array}$} & \multirow{2}{*}{$\begin{array}{l}\text { Пока- } \\
\text { за- } \\
\text { тели }\end{array}$} & \multicolumn{5}{|c|}{$\begin{array}{l}\text { Цитоэнзимохимические показатели зависимости от сроков } \\
\text { лечения }(\mathrm{M} \pm \mathrm{m})\end{array}$} \\
\hline & & $\begin{array}{l}\text { усред- } \\
\text { ненная } \\
\text { норма }\end{array}$ & $\begin{array}{l}\text { до } \\
\text { лечения }\end{array}$ & $\begin{array}{l}\text { через } \\
\text { сутки } \\
\text { после } \\
\text { лечения }\end{array}$ & $\begin{array}{l}\text { через } \\
15 \text { суток } \\
\text { после } \\
\text { лечения }\end{array}$ & $\begin{array}{l}\text { через } \\
30 \text { суток } \\
\text { после } \\
\text { лечения }\end{array}$ \\
\hline \multirow[t]{4}{*}{ Гранулирующий } & МПО & $1,61 \pm 0,02$ & $\begin{array}{l}0,60 \pm 0,02 \\
p<0,01\end{array}$ & $\begin{array}{l}0,72 \pm 0,04 \\
\text { p }<0,01 \\
\text { p } 1<0,01\end{array}$ & $\begin{array}{l}1,24 \pm 0,03 \\
\text { p }<0,01 \\
\text { p } 1<0,01\end{array}$ & $\begin{array}{l}1,58 \pm 0,01 \\
p>0,01 \\
p 1<0,01\end{array}$ \\
\hline & КБ & $1,45 \pm 0,02$ & $\begin{array}{l}0,73 \pm 0,03 \\
\mathrm{p}<0,01\end{array}$ & $\begin{array}{l}1,01 \pm 0,01 \\
\mathrm{p}<0,01 \\
\mathrm{p} 1<0,01\end{array}$ & $\begin{array}{l}1,17 \pm 0,02 \\
\mathrm{p}<0,01\end{array}$ & $\begin{array}{l}1,43 \pm 0,01 \\
p>0,01 \\
p 1<0,01\end{array}$ \\
\hline & ЩФ & $1,98 \pm 0,01$ & $\begin{array}{l}2,42 \pm 0,02 \\
\mathrm{p}<0,01\end{array}$ & $\begin{array}{l}2,35 \pm 0,01 \\
\mathrm{p}<0,01 \\
\mathrm{p} 1<0,01\end{array}$ & $\begin{array}{l}2,21 \pm 0,01 \\
p<0,001 \\
\text { p } 1<0,01\end{array}$ & $\begin{array}{l}1,96 \pm 0,01 \\
p>0,01 \\
p 1<0,01\end{array}$ \\
\hline & КФ & $1,44 \pm 0,02$ & $\begin{array}{l}2,05 \pm 0,03 \\
\mathrm{p}<0,01\end{array}$ & $\begin{array}{l}1,92 \pm 0,02 \\
\text { p }<0,01 \\
\text { p } 1<0,01\end{array}$ & $\begin{array}{l}1,77 \pm 0,03 \\
\text { p }<0,01 \\
\text { p } 1<0,01\end{array}$ & $\begin{array}{l}1,43 \pm 0,01 \\
p>0,01 \\
\text { p } 1<0,01\end{array}$ \\
\hline \multirow[t]{4}{*}{ Гранулематозный } & МПО & $1,61 \pm 0,02$ & $\begin{array}{l}0,50 \pm 0,03 \\
\mathrm{p}<0,01\end{array}$ & $\begin{array}{l}0,70 \pm 0,02 \\
\mathrm{p}<0,01 \\
\mathrm{p} 1<0,01\end{array}$ & $\begin{array}{l}1,25 \pm 0,03 \\
\text { p }<0,01 \\
\text { p1<0,01 }\end{array}$ & $\begin{array}{l}1,56 \pm 0,02 \\
p>0,01 \\
\text { p } 1<0,01\end{array}$ \\
\hline & КБ & $1,43 \pm 0,04$ & $\begin{array}{l}0,71 \pm 0,02 \\
\mathrm{p}<0,01\end{array}$ & $\begin{array}{l}1,04 \pm 0,03 \\
\text { p }<0,01 \\
\text { p } 1<0,01\end{array}$ & $\begin{array}{l}1,15 \pm 0,02 \\
\text { p }<0,01 \\
\text { p } 1<0,01\end{array}$ & $\begin{array}{l}1,40 \pm 0,02 \\
p>0,01 \\
\text { p } 1<0,01\end{array}$ \\
\hline & ЩФ & $1,96 \pm 0,03$ & $\begin{array}{l}2,44 \pm 0,02 \\
\mathrm{p}<0,01\end{array}$ & $\begin{array}{l}2,37 \pm 0,01 \\
\text { p }<0,01 \\
\text { p } 1<0,01\end{array}$ & $\begin{array}{l}2,19 \pm 0,01 \\
\text { p }<0,01 \\
\text { p } 1<0,01\end{array}$ & $\begin{array}{l}1,98 \pm 0,01 \\
p>0,01 \\
\text { p } 1<0,01\end{array}$ \\
\hline & КФ & $1,43 \pm 0,02$ & $\begin{array}{l}2,07 \pm 0,03 \\
\mathrm{p}<0,01\end{array}$ & $\begin{array}{l}1,91 \pm 0,02 \\
\mathrm{p}<0,01 \\
\mathrm{p} 1<0,01\end{array}$ & $\begin{array}{l}1,78 \pm 0,02 \\
p<0,01 \\
\text { p } 1<0,01\end{array}$ & $\begin{array}{l}1,45 \pm 0,01 \\
p>0,01 \\
p 1<0,01\end{array}$ \\
\hline
\end{tabular}

Примечание: $\mathrm{p}$ - достоверность по отношению к индивидуальной норме, p1 - по отношению к показателям до лечения

Таким образом, развитие обострения хронических верхушечных периодонтитов приводило к нарушению функциональной активности нейтрофилов периферической крови больных, взятой из десны со стороны 
больного зуба. Максимальное изменение изученных цитоэнзимохимических маркеров происходило при обострении гранулирующей и гранулематозной формы заболевания. После проведенного лечения в течение 30 суток наблюдалось полное восстановление показателей всех изученных цитоэнзимохимических маркеров, что свидетельствовало об эффективности предложенного нами способа лечения обострившихся хронических верхушечных периодонтитов с применением антисептика велтосепт и ультразвука для дезинфекции системы каналов зуба и света «Bioptron» для купирования воспалительного процесса, а также предложенной нами эндодонтической пасты, содержащей велтосепт и гидроксиапатит «Остеоиндуцин».

\section{6 Отдаленные клинико-рентгенологические результаты лечения} острых и обострившихся хронических периодонтитов под воздействием различных лечебных комплексов.

Спустя 3, 6 и 12 месяцев после лечения ОВП и ОХВП различными лечебными комплексами проводилось клинико-рентгенологическое обследование пациентов с целью изучения состояния репаративных процессов в периодонте. Отдаленные результаты после лечения острых форм верхушечных периодонтитов рентгенологически оценивались по индексу PAI в зависимости от степени восстановления костной ткани в периапикальной области или возникновения костных деструкций под воздействием проводимого лечебного комплекса.

При трактовке значения PAI состояние, соответствующее 1 баллу, оценивали как нормальный верхушечный периодонт (при ОВПСИ), после лечения как полное восстановление костной ткани; 2 балла - костные структурные изменения не типичные для апикального периодонтита (при ОВПСЭ), после лечения как частичное восстановление костной ткани; 3 балла - костные структурные изменения с незначительной потерей минеральной части, после лечения как расширение периодонтальной щели (благоприятный исход лечения гранулирующих и гранулематозных форм); 4 
балла - хорошо видимое затемнение без четких границ (на рентгенограммах при ОХВГрП); 5 баллов - выраженное наличие деструктивных изменений с четкими округлыми формами (ОХВГП).

Таблица 34

Рентгенологическая оценка зависимости репаративных процессов костной ткани в периапикальной области от воздействия лечебных комплексов по индексу РАI при лечении ОВПСИ (первая группа)

\begin{tabular}{|c|c|c|c|c|c|c|}
\hline \multirow{3}{*}{$\begin{array}{l}\text { Под } \\
\text { груп- } \\
\text { па }\end{array}$} & \multirow[b]{3}{*}{ Комплекс лечебных воздействий } & \multirow{3}{*}{$\begin{array}{c}\text { Сроки } \\
\text { наблю- } \\
\text { дений } \\
\text { (мес.) } \\
\end{array}$} & \multicolumn{4}{|c|}{$\begin{array}{l}\text { Периапикальный индекс PAI } \\
\text { (в баллах) }\end{array}$} \\
\hline & & & \multicolumn{2}{|c|}{1 балл } & \multicolumn{2}{|c|}{2 балла } \\
\hline & & & абс. & $\%$ & абс. & $\%$ \\
\hline \multirow{3}{*}{1} & \multirow{3}{*}{$0,2 \%$ РХГ $+Э B$} & 3 & 0 & 0 & 10 & 100 \\
\hline & & 6 & 0 & 0 & 10 & 100 \\
\hline & & 12 & 0 & 0 & 10 & 100 \\
\hline \multirow{3}{*}{2} & \multirow{3}{*}{ 0,2\% РВС + ВСП № 1} & 3 & 10 & 100 & 0 & 0 \\
\hline & & 6 & 10 & 100 & 0 & 0 \\
\hline & & 12 & 10 & 100 & 0 & 0 \\
\hline \multirow{3}{*}{3} & \multirow{3}{*}{ 0,2\% РВС+УЗ+ВСП № 1 ГШ } & 3 & 10 & 100 & 0 & 0 \\
\hline & & 6 & 10 & 100 & 0 & 0 \\
\hline & & 12 & 10 & 100 & 0 & 0 \\
\hline \multirow{3}{*}{4} & \multirow{3}{*}{ 0,2\% РВС++УЗ+БТ+ВСПОИ № 2 ГШ } & 3 & 10 & 100 & 0 & 0 \\
\hline & & 6 & 10 & 100 & 0 & 0 \\
\hline & & 12 & 10 & 100 & 0 & 0 \\
\hline \multirow{3}{*}{5} & \multirow{3}{*}{$\begin{array}{l}0,2 \% \text { РВС+У3+БТ+ОТ «Кальсепт»+ } \\
\text { ВСПОИ № } 2 \text { ГШ }\end{array}$} & 3 & 10 & 100 & 0 & 0 \\
\hline & & 6 & 10 & 100 & 0 & 0 \\
\hline & & 12 & 10 & 100 & 0 & 0 \\
\hline
\end{tabular}

При контрольных обследованиях рентгенологически выделялась группа пациентов с полным восстановлением костной ткани в апикальном периодонте и оценивалась 1 баллом по индексу PAI, вторая группа с частичным восстановлением (2 балла). Поскольку расширение периодонтальной щели после лечения ОХВГрП и ОХВГП расценивалось положительным результатом в отдаленные сроки наблюдений, то по индексу PAI это состояние обозначалось 3 баллами и относилось также к частичному восстановлению костной ткани. Все три позиции (один, два и три балла) по индексу PAI относили к положительной динамике. К отрицательной динамике по индексу PAI относили очаги деструкций без изменений: 4 балла - разрежение костных структур без четких границ и 5 баллов - очаги деструкции костной ткани с выраженными гистологическими признаками 
структурных изменений (гранулема). Отдаленные результаты лечения острых форм верхушечных периодонтитов представлены в таблицах 34 и 35.

Таблица 35

Рентгенологическая оценка зависимости репаративных процессов костной ткани в периапикальной области по периодонтальному индексу РАІ в отдаленные сроки наблюдений при лечении ОВПСЭ

(вторая группа)

\begin{tabular}{|c|c|c|c|c|c|c|c|c|c|}
\hline \multirow{3}{*}{ 絪 } & \multirow{3}{*}{$\begin{array}{c}\text { Комплекс } \\
\text { воздействия } \\
\text { на периодонт }\end{array}$} & \multirow{3}{*}{$\begin{array}{l}\text { Кол- } \\
\text { во } \\
\text { наб- } \\
\text { люде- } \\
\text { ний }\end{array}$} & \multirow{3}{*}{$\begin{array}{l}\text { Сроки } \\
\text { наб- } \\
\text { люде- } \\
\text { ний } \\
\text { (мес.) } \\
\end{array}$} & \multicolumn{6}{|c|}{ Периапикальный индекс РАI (в баллах) } \\
\hline & & & & \multicolumn{2}{|c|}{1 балл } & \multicolumn{2}{|c|}{2 балла } & \multicolumn{2}{|c|}{3 балла } \\
\hline & & & & aбc & $\%$ & aбc & $\%$ & абс & $\%$ \\
\hline \multirow{3}{*}{6} & \multirow{3}{*}{$\begin{array}{c}0,2 \% \\
\text { РХГ+ЭВ (ТР) }\end{array}$} & \multirow{3}{*}{10} & 3 & 0 & 0,00 & 6 & 60,00 & 4 & 40,00 \\
\hline & & & 6 & 0 & 0,00 & 7 & 70,00 & 3 & 30,00 \\
\hline & & & 12 & 0 & 0,00 & 8 & 80,00 & 2 & 20,00 \\
\hline \multirow[t]{3}{*}{7} & \multirow[t]{3}{*}{$\begin{array}{c}0,2 \% \mathrm{PBC}+ \\
\text { ВСП № } 1 \text { (ТР) }\end{array}$} & \multirow[t]{3}{*}{10} & 3 & 7 & $\begin{array}{c}70,00 \\
\mathrm{p}<0,01\end{array}$ & 3 & $\begin{array}{c}30,00 \\
p>0,05\end{array}$ & 0 & $\begin{array}{c}0,00 \\
p<0,05\end{array}$ \\
\hline & & & 6 & 8 & $\begin{array}{c}80,00 \\
\mathrm{p}<0,01\end{array}$ & 2 & $\begin{array}{c}20,00 \\
p<0,02\end{array}$ & 0 & $\begin{array}{c}0,00 \\
p>0,05\end{array}$ \\
\hline & & & 12 & 10 & $\begin{array}{c}100 \\
p<0,01\end{array}$ & 0 & $\begin{array}{c}0,00 \\
p<0,01\end{array}$ & 0 & $\begin{array}{c}0,00 \\
p>0,05\end{array}$ \\
\hline \multirow[t]{3}{*}{8} & \multirow{3}{*}{$\begin{array}{c}0,2 \% \text { РВС+ } \\
\text { У3+ВСП } \\
\text { №1+ГШ (ТР) }\end{array}$} & \multirow[t]{3}{*}{10} & 3 & 8 & $\begin{array}{c}80,00 \\
\mathrm{p}<0,01\end{array}$ & 2 & $\begin{array}{c}20,00 \\
p>0,05\end{array}$ & 0 & $\begin{array}{c}0,00 \\
p<0,05\end{array}$ \\
\hline & & & 6 & 9 & $\begin{array}{c}90,00 \\
p<0,01\end{array}$ & 1 & $\begin{array}{c}10,00 \\
p<0,01\end{array}$ & 0 & $\begin{array}{c}0,00 \\
p>0,05\end{array}$ \\
\hline & & & 12 & 10 & $\begin{array}{c}100 \\
p<0,01\end{array}$ & 0 & $\begin{array}{c}0,00 \\
p<0,01\end{array}$ & 0 & $\begin{array}{c}0,00 \\
p>0,05\end{array}$ \\
\hline \multirow[t]{3}{*}{9} & \multirow{3}{*}{$\begin{array}{c}0,2 \% \text { РВС+У3 } \\
+ \text { БТ+ } \\
\text { ВСПОИ№2+ } \\
\text { ГШ (ТР) }\end{array}$} & \multirow[t]{3}{*}{10} & 3 & 10 & $\begin{array}{c}100 \\
p<0,01\end{array}$ & 0 & $\begin{array}{c}0,00 \\
p<0,01\end{array}$ & 0 & $\begin{array}{c}0,00 \\
p<0,05\end{array}$ \\
\hline & & & 6 & 10 & $\begin{array}{c}100 \\
p<0,01\end{array}$ & 0 & $\begin{array}{c}0,00 \\
p<0,01\end{array}$ & 0 & $\begin{array}{c}0,00 \\
p>0,05\end{array}$ \\
\hline & & & 12 & 10 & $\begin{array}{c}100 \\
p<0,01\end{array}$ & 0 & $\begin{array}{c}0,00 \\
p<0,01\end{array}$ & 0 & $\begin{array}{c}0,00 \\
p>0,05\end{array}$ \\
\hline \multirow[t]{4}{*}{10} & \multirow{3}{*}{$\begin{array}{c}\text { 0,2\%РВС+ } \\
\text { УЗ+БТ+ } \\
+ \text { Кальсепт+ } \\
+ \text { ВСПОИо2+ } \\
\text { +ГШ (ОТ) }\end{array}$} & \multirow[t]{3}{*}{10} & 3 & 10 & $\begin{array}{c}100 \\
p<0,01\end{array}$ & 0 & $\begin{array}{c}0,00 \\
p<0,01\end{array}$ & 0 & $\begin{array}{c}0,00 \\
p<0,05\end{array}$ \\
\hline & & & 6 & 10 & $\begin{array}{c}100 \\
p<0,01\end{array}$ & 0 & $\begin{array}{c}0,00 \\
p<0,01\end{array}$ & 0 & $\begin{array}{c}0,00 \\
p>0,05\end{array}$ \\
\hline & & & 12 & 10 & $\begin{array}{c}100 \\
p<0,01\end{array}$ & 0 & $\begin{array}{c}0,00 \\
p<0,01\end{array}$ & 0 & $\begin{array}{c}0,00 \\
p>0,05\end{array}$ \\
\hline & Итого & 50 & & & & & & & \\
\hline
\end{tabular}

Примечание: $\mathrm{p}$ - достоверность по отношению к 6 подгруппе

Через три месяца при опросе все 50 пациентов с ОВПСИ жалоб не предъявляли. Объективно слизистая оболочка в области леченых зубов не изменена, все зубы участвовали в акте жевания, пломбы в 48 случаях 
отвечали всем требованиям, в двух случаях пломбы заменены из-за нарушения контактного пункта.

На рентгенограммах в первой подгруппе при воздействии лечебным комплексом с 0,2\% раствором хлоргексидина и пломбированием корневых каналов эвгедентом у всех десяти пациентов корневые каналы запломбированы до уровня верхушки зуба, определялась нечеткость рисунка кортикальной пластинки у верхушки корня и расширение периодонтальной щели с неровными рваными контурами. Полного восстановления костного рисунка в периапикальной области не отмечалось в течение 12 месяцев наблюдений, рентгенологическая картина находилась на уровне трехмесячных наблюдений. Тогда как в подгруппах 4 и 5, где применялся комплекс, состоящий из 0,2\% РВС, ВСПОИ №2 и БТ, как ТР, так и ОТ полное восстановление костной ткани установлено в 100\% случаев.

Несколько иная картина наблюдалась у пациентов с ОВП в стадии экссудации. В шестой подгруппе под воздействием лечебного комплекса $(0,2 \%$ хлоргексидин + «Эвгедент») очаг деструкции без изменений установлен через три месяца в 40,00\%, спустя 12 месяцев в двух случаях. Полного восстановления костной ткани в очагах деструкции в течение всего года наблюдений не произошло. Частичное восстановление зарегистрировано через три месяца в 60,00\% случаев, спустя год - у 80,00\% пациентов, у которых отмечались нечеткость рисунка кортикальной пластинки у верхушки корня, неравномерное расширение периодонтальной щели.

В 7 подгруппе, где пациентам с ОВП в стадии экссудации, корневые каналы пломбировались велтосепт-пастой № 1 с предварительной медикаментозной обработкой их 0,2\% раствором велтосепта, спустя три месяца установлено полное восстановление костных структур в 70,00\% случаев, спустя год - в 100\% случаев и лишь в трех случаях - через три месяца и в двух - через шесть месяцев произошло частичное восстановление, где костные балочки находились на стадии завершения процесса регенерации. 
В 8 подгруппе (комплекс 0,2\% РВС+УЗ + ВСП №1 + ГШ) спустя шесть месяцев в 90,00\% случаев зарегистрировано полное восстановление костных структур, через 12 месяцев - в 100\% случаев. В 9 и 10 подгруппах под воздействием лечебных комплексов, состоящих из озвученного $0,2 \% \mathrm{PBC}+$ ВСПОИ №2 и света «Bioptron», ТР (9 ПГР) и ОТ (10 ПГР) полное восстановление костных структур наблюдалось у всех пациентов уже спустя три месяца после лечения.

Таким образом, в подгруппах 4, 5, 9 и 10, где применялся пломбировочный материал: ВСПОИ № 2 регенеративные процессы в периодонте происходили значительно быстрее. Применение светотерапии способствовало быстрейшему купированию воспалительного процесса в периодонте за счет стимуляции клеток - макрофагов.

Наблюдение №1. Больная И, 21 год, 19.10.07 г. обратилась в стоматологическую поликлинику СтГМА с жалобами на постоянную ноющую боль 11 зуба и общее недомогание. Зуб ранее не болел. Объективно: припухлость в области причинного зуба. Температура тела $-37,8^{0} \mathrm{C}$, слизистая оболочка по переходной складке гиперемирована, отечна, резко болезненна при пальпации. На медиальной поверхности кариозная полость, сообщающаяся с полостью зуба, вертикальная перкуссия резко болезненна. На рентгенограмме в области проекции верхушек корня 11 зуба смазанность костного рисунка. Диагноз: острый периодонтит в стадии экссудации 11 зуба (рисунок 14). Лечение: под инфильтрационной анестезией Sol. Ultracaini 4\% - $2 \mathrm{ml}$ удалена пломба, раскрыта полость зуба, под ванночкой из $0,2 \%$ раствора велтосепта удален распад из корневого канала, дан отток экссудата, медикаментозная обработка каналов велтосептом с ультразвуком. Полость зуба закрыта временной пломбой. Дан совет.

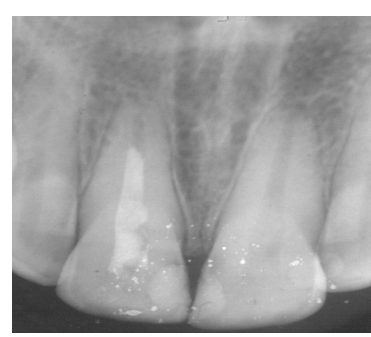

Рис. 14. Наблюдение 1. Рентгенограмма больной И. до лечения

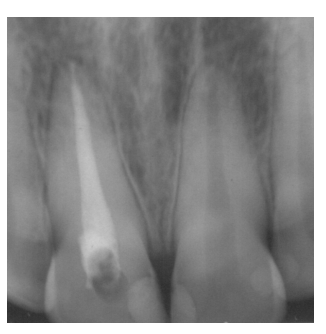

Рис. 15. Наблюдение 1. Рентгенограмма больной И. после пломбирования корневых каналов 
20.10.07. Жалоб нет. Объективно: полость 11 зуба под временной пломбой, перкуссия слабо болезненна, слизистая оболочка в области 11 зуба по переходной складки слегка гиперемирована. Лечение: инструментальная и медикаментозная обработка корневого канала раствором велтосепта и ультразвуком, сеанс светотерапии «Bioptron», повязка из водного дентина.

23.10.07. Жалоб нет. Объективно: 11 зуб под временной пломбой. Лечение - удалена пломба, медикаментозная обработка РВС и УЗ, канал высушен бумажными штифтами и запломбирован ВСПОИ №2 и ГШ до верхушечного отверстия, прокладка из стеклоиномерного цемента «Ionosit», пломба - «Estelite», сеанс светотерапии «Bioptron» (рис.15).

25.01.08. Контрольное обследование через три месяца после лечения. Объективно: 11 под пломбой, перкуссия безболезненна, слизистая оболочка розового цвета. На рентгенограмме корневые каналы равномерно заполнены эндодонтическим пломбировочным материалом. В периодонте в области 11 зуба полное восстановление костных структур (рис.16).

29.04.08. Жалоб нет. Контрольное обследование спустя шесть месяцев после лечения. Объективно: без патологических отклонений. На рентгенограмме полное восстановление костных структур (рис. 17).

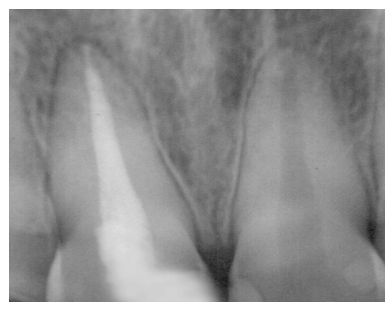

Рис. 16. Наблюдение 1. Рентгенограмма больной И. через 3 месяца после лечения

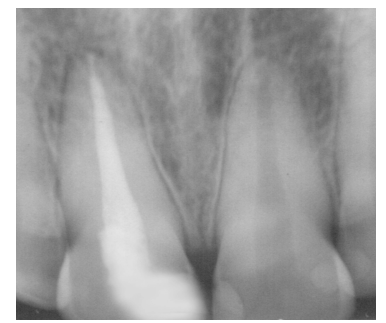

Рис.17. Наблюдение 1. Рентгенограмма больной И. через 6 месяцев после лечения

20.10.08г. Жалоб нет. Контрольное обследование спустя 12 месяцев после лечения. Объективно: без патологических отклонений. На рентгенограмме полное восстановление костных структур (рис. 18).

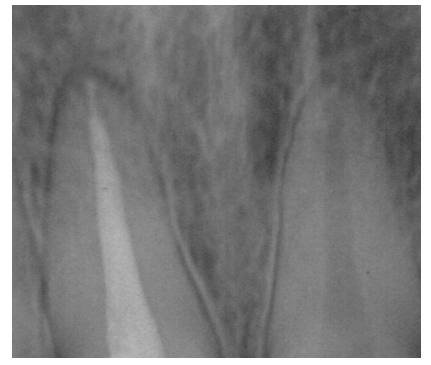

Рис. 18. Наблюдение 1. Рентгенограмма больной И. через 12 месяцев 
Отдаленные сроки наблюдений при лечении ОХВГрП представлены в таблице 36 и 37.

Таблица 36

Рентгенологическая оценка зависимости репаративных процессов костной ткани в периапикальной области по периапикальному индексу РАІ в отдаленные сроки наблюдений при лечении ОХВГрП

(третья группа)

\begin{tabular}{|c|c|c|c|c|c|c|c|}
\hline \multirow{3}{*}{$\begin{array}{l}\text { Под- } \\
\text { груп- } \\
\text { па }\end{array}$} & \multirow[t]{3}{*}{$\begin{array}{c}\text { Комплекс } \\
\text { воздействия }\end{array}$} & \multirow{3}{*}{$\begin{array}{l}\text { Кол-во } \\
\text { наб- } \\
\text { люде- } \\
\text { ний }\end{array}$} & \multirow{3}{*}{$\begin{array}{l}\text { Сроки } \\
\text { наблю- } \\
\text { дений } \\
\text { (мес.) }\end{array}$} & \multicolumn{4}{|c|}{$\begin{array}{c}\text { Периапикальный индекс PAI } \\
\text { (в баллах) }\end{array}$} \\
\hline & & & & \multicolumn{2}{|c|}{1 балл } & \multicolumn{2}{|c|}{2 балла } \\
\hline & & & & абс. & $\%$ & абс. & $\%$ \\
\hline \multirow{3}{*}{11} & \multirow{3}{*}{ 0,2\% РХГ+ЭВ } & \multirow{3}{*}{10} & 3 & 0 & 0,00 & 0 & 0,00 \\
\hline & & & 6 & 0 & 0,00 & 0 & 0,00 \\
\hline & & & 12 & 0 & 0,00 & 0 & 0,00 \\
\hline \multirow{3}{*}{12} & \multirow{3}{*}{$\begin{array}{c}0,2 \% \text { РВC+BCП } \\
\text { № } 1\end{array}$} & \multirow{3}{*}{10} & 3 & 0 & 0,00 & 0 & 0,00 \\
\hline & & & 6 & 0 & 0,00 & 3 & $\begin{array}{l}30,00 \\
p>0,05\end{array}$ \\
\hline & & & 12 & 1 & $\begin{array}{l}10,00 \\
p>0,05\end{array}$ & 2 & $\begin{array}{l}20,00 \\
p>0,05\end{array}$ \\
\hline \multirow[t]{3}{*}{13} & \multirow[t]{3}{*}{$\begin{array}{c}0,2 \% \mathrm{PBC}+\mathrm{У3+} \\
\text { ВСП №1+ГШ }\end{array}$} & \multirow[t]{3}{*}{10} & 3 & 0 & 0,00 & 4 & $\begin{array}{l}40,00 \\
p<0,05\end{array}$ \\
\hline & & & 6 & 2 & $\begin{array}{l}20,00 \\
p>0,05\end{array}$ & 3 & $\begin{array}{l}30,00 \\
p>0,05\end{array}$ \\
\hline & & & 12 & 3 & $\begin{array}{l}30,00 \\
p>0,05\end{array}$ & 2 & $\begin{array}{l}20,00 \\
p>0,05\end{array}$ \\
\hline \multirow{3}{*}{14} & \multirow{3}{*}{$\begin{array}{c}\text { 0,2\%РВС+У3 + } \\
\text { ВСПОИ№2+ГШ+БТ } \\
\text { (ТР) }\end{array}$} & \multirow[t]{3}{*}{10} & 3 & 2 & $\begin{array}{l}20,00 \\
p>0,05\end{array}$ & 1 & $\begin{array}{l}10,00 \\
p>0,05\end{array}$ \\
\hline & & & 6 & 4 & $\begin{array}{l}40,00 \\
\mathrm{p}<0,05\end{array}$ & 2 & $\begin{array}{l}20,00 \\
p>0,05\end{array}$ \\
\hline & & & 12 & 6 & $\begin{array}{l}60,00 \\
\mathrm{p}<0,01\end{array}$ & 2 & $\begin{array}{l}20,00 \\
p>0,05\end{array}$ \\
\hline \multirow[t]{3}{*}{15} & \multirow{3}{*}{$\begin{array}{c}0,2 \% \text { РВС+УЗ+ } \\
(« \text { Кальсепт»- ОТ) } \\
+ \text { ВСПОИ№2 +ГШ+БТ }\end{array}$} & \multirow[t]{3}{*}{10} & 3 & 3 & $\begin{array}{l}30,00 \\
p>0,05\end{array}$ & 1 & $\begin{array}{l}10,00 \\
p>0,05\end{array}$ \\
\hline & & & 6 & 5 & $\begin{array}{l}50,00 \\
\mathrm{p}<0,01\end{array}$ & 1 & $\begin{array}{l}10,00 \\
p>0,05\end{array}$ \\
\hline & & & 12 & 7 & $\begin{array}{l}70,00 \\
\mathrm{p}<0,01\end{array}$ & 1 & $\begin{array}{l}10,00 \\
p>0,05\end{array}$ \\
\hline
\end{tabular}

Примечание: $p$ - достоверность по отношению к 11 подгруппе

Анализируя данные таблицы 36 и 37, где проводилась рентгенологическая оценка зависимости репаративных процессов костной ткани в периапикальной области от воздействия различных лечебных комплексов при лечении ОХВГрП установлено: в 11 подгруппе (пломбирование корневых каналов зубов ЭВ в сочетании с медикаментозной обработкой $0,2 \%$ РХГ) очаги деструкции в течение 12 месяцев наблюдений оставались без изменений в $60,00 \%$ случаев и лишь в $40,00 \%$ - частичное, 
тогда как полного восстановления костных структур не зарегистрировано ни в одном случае.

Таблица 37

Рентгенологическая оценка зависимости репаративных процессов костной ткани в периапикальной области по периапикальному индексу РАІ в отдаленные сроки наблюдений при лечении ОХВГрП

(третья группа)

\begin{tabular}{|c|c|c|c|c|c|c|c|}
\hline \multirow{3}{*}{$\begin{array}{l}\text { Под- } \\
\text { груп- } \\
\text { па }\end{array}$} & \multirow{3}{*}{$\begin{array}{c}\text { Комплекс воздействия } \\
\text { на периодонт }\end{array}$} & \multirow{3}{*}{$\begin{array}{c}\text { Кол- } \\
\text { во } \\
\text { наб- } \\
\text { люде- } \\
\text { ний }\end{array}$} & \multirow{3}{*}{$\begin{array}{c}\text { Сроки } \\
\text { наблюд } \\
\text { ений } \\
\text { (мес.) }\end{array}$} & \multicolumn{4}{|c|}{$\begin{array}{c}\text { Периапикальный индекс PAI } \\
\text { (в баллах) }\end{array}$} \\
\hline & & & & \multicolumn{2}{|c|}{3 балла } & \multicolumn{2}{|c|}{4 балла } \\
\hline & & & & aбc. & $\%$ & абс. & $\%$ \\
\hline \multirow{3}{*}{11} & \multirow{3}{*}{$0,2 \%$ РХГ $+Э В$} & \multirow{3}{*}{10} & 3 & 0 & 0,00 & 10 & 100 \\
\hline & & & 6 & 0 & 0,00 & 10 & 100 \\
\hline & & & 12 & 4 & 40,00 & 6 & 60,00 \\
\hline \multirow[t]{3}{*}{12} & \multirow[t]{3}{*}{ 0,2\% РВС+ВСП № 1} & \multirow[t]{3}{*}{10} & 3 & 3 & $\begin{array}{c}30,00 \\
p>0,05\end{array}$ & 7 & $\begin{array}{l}70,00 \\
p>0,05\end{array}$ \\
\hline & & & 6 & 3 & $\begin{array}{c}30,00 \\
p>0,05\end{array}$ & 4 & $\begin{array}{l}40,00 \\
p<0,01\end{array}$ \\
\hline & & & 12 & 3 & $\begin{array}{c}30,00 \\
\mathrm{p}>0,05\end{array}$ & 4 & $\begin{array}{l}40,00 \\
p>0,05\end{array}$ \\
\hline \multirow[t]{3}{*}{13} & \multirow[t]{3}{*}{$\begin{array}{c}0,2 \% \text { РВС+УЗ+ } \\
\text { ВСП №1+ГШ }\end{array}$} & \multirow[t]{3}{*}{10} & 3 & 4 & $\begin{array}{c}40,00 \\
\mathrm{p}<0,05\end{array}$ & 2 & $\begin{array}{l}20,00 \\
\mathrm{p}<0,01\end{array}$ \\
\hline & & & 6 & 4 & $\begin{array}{l}40,00 \\
\mathrm{p}<0,05\end{array}$ & 1 & $\begin{array}{l}10,00 \\
\mathrm{p}<0,01\end{array}$ \\
\hline & & & 12 & 4 & 40,00 & 1 & $\begin{array}{c}10,00 \\
\mathrm{p}<0,02\end{array}$ \\
\hline \multirow[t]{3}{*}{14} & \multirow[t]{3}{*}{$\begin{array}{c}\text { 0,2\%РВС+У3 + } \\
\text { ВСПОИ№2+ГШ+БТ }\end{array}$} & \multirow[t]{3}{*}{10} & 3 & 2 & $\begin{array}{c}20,00 \\
\mathrm{p}>0,05\end{array}$ & 5 & $\begin{array}{c}50,00 \\
\mathrm{p}<0,01\end{array}$ \\
\hline & & & 6 & 2 & $\begin{array}{c}20,00 \\
\mathrm{p}>0,05\end{array}$ & 2 & $\begin{array}{c}20,00 \\
\mathrm{p}<0,01\end{array}$ \\
\hline & & & 12 & 2 & $\begin{array}{l}20,00 \\
p>0,05\end{array}$ & 0 & $\begin{array}{c}0,00 \\
\mathrm{p}<0,01\end{array}$ \\
\hline \multirow[t]{3}{*}{15} & \multirow{3}{*}{$\begin{array}{c}0,2 \% \text { РВС+УЗ+ } \\
(« \text { Кальсепт»-ОТ) } \\
+ \text { ВСПОИ№2 +ГШ+БТ }\end{array}$} & \multirow[t]{3}{*}{10} & 3 & 1 & $\begin{array}{c}10,00 \\
p>0,05\end{array}$ & 5 & $\begin{array}{c}50,00 \\
\mathrm{p}<0,01\end{array}$ \\
\hline & & & 6 & 1 & $\begin{array}{c}10,00 \\
\mathrm{p}>0,05\end{array}$ & 3 & $\begin{array}{c}30,00 \\
\mathrm{p}<0,01\end{array}$ \\
\hline & & & 12 & 2 & $\begin{array}{c}20,00 \\
p>0,05\end{array}$ & 0 & $\begin{array}{c}0,00 \\
\mathrm{p}<0,01\end{array}$ \\
\hline
\end{tabular}

Примечание: p - достоверность по отношению к 11 подгруппе

В подгруппах 12 и 13, пациентам, у которых корневые каналы пломбировались ВСП №1 в сочетании с антимикробной обработкой системы корневых каналов 0,2\% РВС и УЗ (13 пгр) и без него (12 пгр), установлено полное восстановление костной ткани в периапикальной области у 10,00\% и $30,00 \%$ пациентов соответственно; частичное - в 20,00\% случаев в обоих 
подгруппах; расширение периодонтальной щели, как благоприятный исход восстановления деструктивных изменений при лечении ОХВГрП зарегистрировано в $30,00 \%$ и $40,00 \%$.

Соответственно, очаги деструкции находились без изменений у 40,00\% и 10,00\% больных спустя 12 месяцев после лечения (рис. 19).

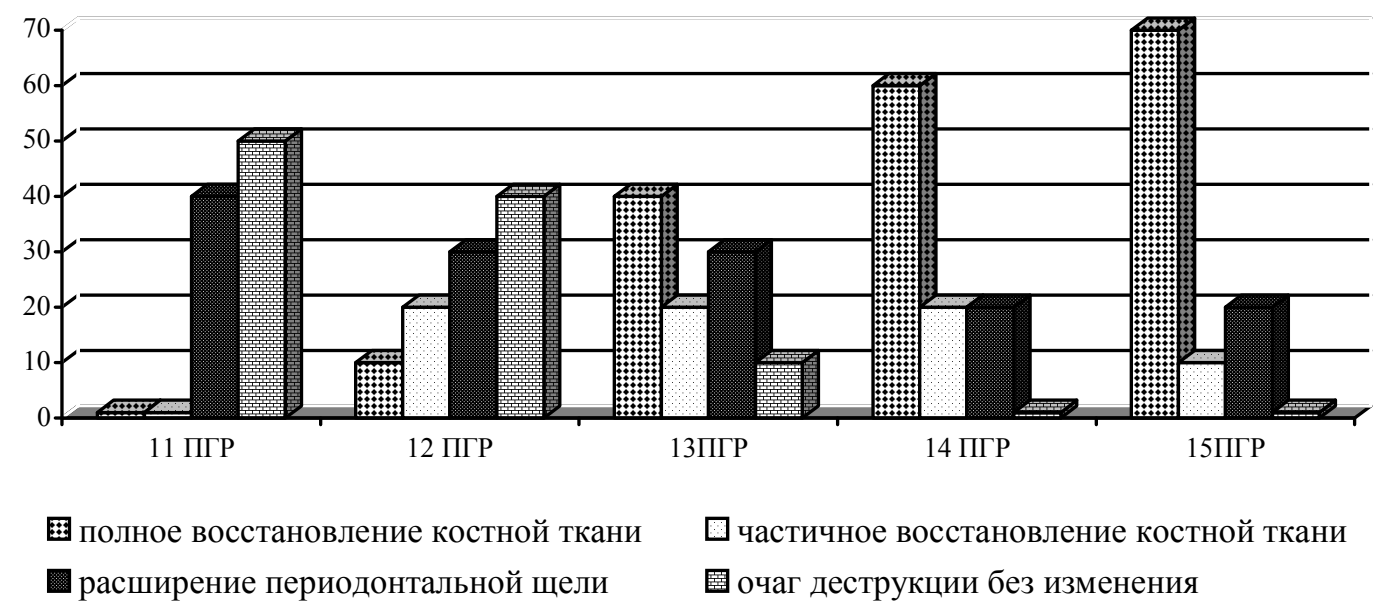

Рис. 19. Восстановление костной ткани в периапикальной области в зависимости от комплекса лечебных воздействий по рентгенологическим данным спустя 12 месяцев после лечения ОХВГрП (третья группа)

В подгруппах 14 и 15, пациентам, которым проводилось пломбирование корневых каналов велтосепт-пастой №2 с ультрадисперсным гидроксиапатитом «Остеоиндуцин» в комплексе с антисептическим воздействием ирриганта велтосепт в озвученной среде и полихроматичного света «Bioptron» традиционным (14 пгр) и отсроченным (15 пгр) методами, зарегистрированы наилучшие результаты: очагов деструкции без изменений не определялось на рентгенограммах ни в одном случае; полное восстановление костной ткани установлено в $60,00 \%$ и $70,00 \%$ случаев, частичное с расширением периодонтальной щели в 40,00\% и $30,00 \%$ случаев соответственно спустя 12 месяцев после лечения.

Рентгенологическая оценка отдаленных результатов лечения ОХВГП различными лечебными комплексами представлена в таблице 38 . В подгруппах 16, 17, 18, 19, 20 изучалось воздействие различных лечебных комплексов на резорбированную костную ткань в периапикальной области при лечении ОХВГП. Анализ рентгенограмм в подгруппе 16, где корневые 
каналы пломбировались эвгедентом в сочетании с медикаментозной обработкой корневых каналов зубов $0,2 \%$ РХГ, очаги деструкции в течение 12 месяцев наблюдений оставались без изменений в 100\% обследованных больных.

Таблица 38

Рентгенологическая оценка зависимости репаративных процессов костной ткани в периапикальной области по периапикальному индексу PАІ в отдаленные сроки наблюдений при лечении ОХВГП (четвертая группа)

\begin{tabular}{|c|c|c|c|c|c|c|c|c|c|c|c|}
\hline \multirow{3}{*}{$\begin{array}{l}\Pi \\
\mathrm{O} \\
Д \\
\Gamma \\
\mathrm{P} \\
\mathrm{y} \\
\Pi \\
\Pi \\
\mathrm{A}\end{array}$} & \multirow{3}{*}{$\begin{array}{c}\text { Сроки } \\
\text { наб- } \\
\text { люде- } \\
\text { ний } \\
\text { (мес.) }\end{array}$} & \multicolumn{10}{|c|}{ Периапикальный индекс РАI (в баллах) } \\
\hline & & \multicolumn{2}{|c|}{$\begin{array}{c}1 \text { балл } \\
\text { Полное } \\
\text { восстановлен } \\
\text { ие костной } \\
\text { ткани }\end{array}$} & \multicolumn{2}{|c|}{$\begin{array}{c}2 \text { балла } \\
\text { Частичное } \\
\text { восстановле } \\
\text { ние } \\
\text { костной } \\
\text { ткани }\end{array}$} & \multicolumn{2}{|c|}{$\begin{array}{c}3 \text { балла } \\
\text { Очаг } \\
\text { деструкции с } \\
\text { незначительнь } \\
\text { м расширением } \\
\text { периодонталь- } \\
\text { ной щели }\end{array}$} & \multicolumn{2}{|c|}{$\begin{array}{c}4 \text { балла } \\
\text { Разрежение } \\
\text { костных } \\
\text { структур без } \\
\text { четких } \\
\text { границ }\end{array}$} & \multicolumn{2}{|c|}{$\begin{array}{c}5 \text { баллов } \\
\text { Очаг } \\
\text { деструкции } \\
\text { без } \\
\text { изменения }\end{array}$} \\
\hline & & абс. & $\%$ & абс. & $\%$ & абс. & $\%$ & абс. & $\%$ & абс. & $\%$ \\
\hline \multirow{3}{*}{16} & 3 & 0 & 0,00 & 0 & 0,00 & 0 & 0,00 & 0 & 0,00 & 10 & 100 \\
\hline & 6 & 0 & 0,00 & 0 & 0,00 & 0 & 0,00 & 0 & 0,00 & 10 & 100 \\
\hline & 12 & 0 & 0,00 & 0 & 0,00 & 0 & 0,00 & 0 & 0,00 & 10 & 100 \\
\hline \multirow[t]{3}{*}{17} & 3 & 0 & 0,00 & 0 & 0,00 & 0 & 0,00 & 4 & $\begin{array}{c}40,00 \\
p<0,05\end{array}$ & 6 & $\begin{array}{c}60,00 \\
p<0,05\end{array}$ \\
\hline & 6 & 0 & 0,00 & 0 & 0,00 & 3 & $\begin{array}{c}30,00 \\
p<0,05\end{array}$ & 4 & $\begin{array}{c}40,00 \\
\mathrm{p}<0,01\end{array}$ & 3 & $\begin{array}{c}30,00 \\
p<0,01\end{array}$ \\
\hline & 12 & 1 & 10,00 & 1 & $\begin{array}{c}10,00 \\
p<0,01\end{array}$ & 2 & $\begin{array}{c}20,00 \\
p<0,05\end{array}$ & 1 & $\begin{array}{c}10,00 \\
p>0,05\end{array}$ & 5 & $\begin{array}{c}50,00 \\
\mathrm{p}<0,01\end{array}$ \\
\hline \multirow[t]{3}{*}{18} & 3 & 0 & 0,00 & 0 & 0,00 & 3 & $\begin{array}{c}30,00 \\
p<0,01\end{array}$ & 2 & $\begin{array}{c}20,00 \\
p>0,05\end{array}$ & 5 & $\begin{array}{c}50,00 \\
p<0,01\end{array}$ \\
\hline & 6 & 0 & 0,00 & 0 & 0,00 & 5 & $\begin{array}{c}50,00 \\
p<0,01\end{array}$ & 2 & $\begin{array}{c}20,00 \\
p>0,05\end{array}$ & 3 & $\begin{array}{c}30,00 \\
p<0,01\end{array}$ \\
\hline & 12 & 2 & $\begin{array}{c}20,00 \\
p<0,01\end{array}$ & 1 & $\begin{array}{c}10,00 \\
p<0,05\end{array}$ & 4 & $\begin{array}{c}40,00 \\
p<0,05\end{array}$ & 1 & $\begin{array}{c}10,00 \\
p>0,05\end{array}$ & 2 & $\begin{array}{c}20,00 \\
p<0,01\end{array}$ \\
\hline \multirow[t]{3}{*}{19} & 3 & 0 & 0,00 & 1 & $\begin{array}{c}10,00 \\
p<0,05\end{array}$ & 2 & $\begin{array}{c}20,00 \\
p<0,05\end{array}$ & 3 & $\begin{array}{c}30,00 \\
p>0,05\end{array}$ & 4 & $\begin{array}{c}40,00 \\
p<0,01\end{array}$ \\
\hline & 6 & 1 & 10,00 & 1 & $\begin{array}{c}10,00 \\
p<0,05\end{array}$ & 4 & $\begin{array}{c}40,00 \\
p<0,05\end{array}$ & 1 & $\begin{array}{c}10,00 \\
p>0,05\end{array}$ & 3 & $\begin{array}{c}30,00 \\
p<0,01\end{array}$ \\
\hline & 12 & 6 & $\begin{array}{c}60,00 \\
p<0,01\end{array}$ & 0 & $\begin{array}{c}0,00 \\
p<0,05\end{array}$ & 4 & $\begin{array}{c}40,00 \\
p<0,05\end{array}$ & 0 & 0,00 & 0 & $\begin{array}{c}0,00 \\
p<0,01\end{array}$ \\
\hline \multirow[t]{3}{*}{20} & 3 & 0 & 0,00 & 0 & 0,00 & 1 & $\begin{array}{c}10,00 \\
p<0,01\end{array}$ & 4 & $\begin{array}{c}40,00 \\
p<0,05\end{array}$ & 5 & $\begin{array}{c}50,00 \\
p<0,01\end{array}$ \\
\hline & 6 & 3 & $\begin{array}{c}30,00 \\
p<0,01\end{array}$ & 1 & $\begin{array}{c}10,00 \\
p<0,05\end{array}$ & 2 & $\begin{array}{c}20,00 \\
p<0,05\end{array}$ & 4 & $\begin{array}{c}40,00 \\
p<0,01\end{array}$ & 0 & $\begin{array}{c}0,00 \\
\mathrm{p}<0,01\end{array}$ \\
\hline & 12 & 6 & $\begin{array}{c}60,00 \\
p<0,01\end{array}$ & 0 & $\begin{array}{c}0,00 \\
p<0,05\end{array}$ & 4 & $\begin{array}{c}40,00 \\
p<0,05\end{array}$ & 0 & 0,00 & 0 & $\begin{array}{c}0,00 \\
p<0,01\end{array}$ \\
\hline
\end{tabular}

Примечание: $\mathrm{p}$ - достоверность по отношению к 16 подгруппе 
В 17 и 18 подгруппах изучалось воздействие на очаги деструкции в апикальном периодонте лечебных комплексов, состоящих из пломбирования корневых каналов велтосепт-пастой №1 в комплексе с воздействием на микрофлору системы корневых каналов 0,2\% раствором велтосепта с ультразвуком внутриканально (18 пгр) и без него (17 пгр). Полное восстановление костной ткани в периапикальной области достигнуто в $10,00 \%$ и $20,00 \%$ случаев соответственно, частичное восстановление (в том числе и расширение периодонтальной щели) - у 30,00\% и 50,00\% пациентов; в $60,00 \%$ и $30,00 \%$ случаев соответственно в подгруппах очаг деструкции имел разрежение костных структур на рентгенограммах или четко выраженную гранулему без изменений.

В подгруппах 19 и 20 изучались идентичные комплексы традиционным (19 пгр) и отсроченным (20 пгр) методами, состоящими из пломбирования корневых каналов зубов велтосепт-пастой № 2 с ультрадисперсным гидроксиапатитом «Остеоиндуцин», в 20 пгр каналы пломбировались временным пломбировочным материалом - «Кальсепт» (на 1 месяц) с последующим удалением и пломбированием каналов велтосепт-пастой №2. Перед пломбированием система корневых каналов обрабатывалась 0,2\% раствором велтосепта с последующим воздействием ультразвука аппарата «Amdent US 30 D» внутриканально. До и после окончания лечения на область леченого зуба чрезкожно воздействовали светом «Bioptron» (5 сеансов).

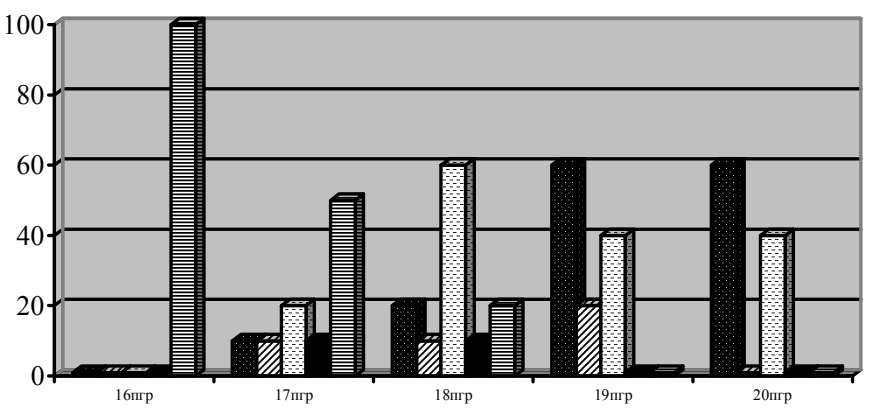

полное восстановление костной ткани

частичное восстановление костной ткани

울 расширение периодонтальной щели

очаг деструкции с нечеткими границами

目 очаг деструкции без изменения

Рис. 20. Восстановление костной ткани в периапикальной области в зависимости от комплекса лечебных воздействий по рентгенологическим данным спустя 12 месяцев после лечения ОХВГП (четвертая группа) 
Под воздействием данных лечебных комплексов полное восстановление костных структур в периапикальной области через 12 месяцев после лечения достигнуто в $60,00 \%$ случаев как традиционным, так и отсроченным методами. Частичное восстановление костной ткани зарегистрировано в 40,00\% случаев. Отрицательной динамики спустя год после лечения не было отмечено (рис.20).

Наблюдение 2. Больной А, 25 лет. Обратился в стоматологическую поликлинику 15.03.08г. с жалобами на постоянную ноющую, нарастающую боль в области 23 зуба. Зуб беспокоит, со слов больного, в течение года периодическими болями при накусывании. Обращался к стоматологу, было проведено лечение и поставлена пломба. Два дня назад появилась припухлость слизистой оболочки в области переходной складки и боль при накусывании на 23 зуб. Объективно: на язычной поверхности 23 зуба кариозная полость. Вертикальная перкуссия зуба резко болезненна, слизистая оболочка в области причинного зуба гиперемирована, отечна, болезненна. На рентгенограмме в периодонтальной области определяется разряжение костной ткани с четкими округлыми контурами, размером $0,3 \times 0,2 \mathrm{~cm}$. Диагноз: хронический гранулематозный периодонтит в стадии обострения (рис.21). Лечение: под инфильтрационной анестезией Sol. Ultracaini 4\% (2,0 $\mathrm{ml})$ произведено препарирование кариозной полости зуба, проведена эвакуация распада из корневого канала, инструментальная и медикаментозная обработка велтосептом и ультразвуком, получен экссудат, полость зуба закрыта временной пломбой.

16.03.08г. Жалобы на слабую болезненность при накусывании на 23 зуб. Объективно: полость зуба закрыта временной пломбой. Вертикальная перкуссия и пальпация переходной складки слабо болезненна. Лечение: канал 23 зуба повторно промыты велтосептом и обработаны ультразвуком, проведено лечение светом «Bioptron», поставлена временная пломба, дан совет.

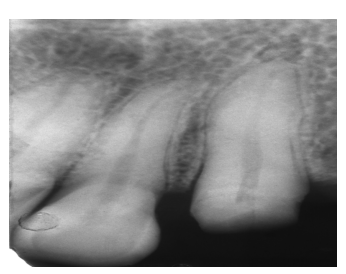

Рис. 21 Наблюдение 2. Рентгенограмма больного А. при первом обращении к врачу

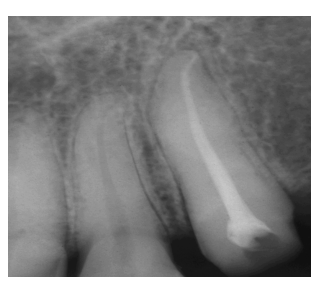

Рис. 22. Наблюдение 2. Рентгенограмма больного А. после пломбирования

19.03.08г. Жалоб нет. Объективно: 23 зуб под временной пломбой, перкуссия безболезненна, слизистая оболочка бледно-розового цвета. Лечение: удалена временная 
пломба, каналы промыты раствором велтосепта в сочетании с ультразвуком, запломбированы велтосепт-пастой № 2 с остеоиндуцином, пломба из стеклоиномерного цемента, сеанс света «Bioptron» (рис.22).

20.03.08г. Жалоб нет. Объективно: 23 зуб под пломбой, перкуссия безболезненна, слизистая оболочка не изменена. Проведен сеанс светотерапии.

15.06.08г. Контрольное обследование через три месяца после лечения. Объективно: 23 зуб под пломбой. Отклонений от нормы нет. На рентгенограмме в периапикальной области отмечается уменьшение размеров очагов деструкции костной ткани на 1/3 (рис.23).

19.09.08г. Контрольное обследование через шесть месяцев после лечения. Жалоб нет. Объективные данные соответствуют норме. На рентгенограмме в периапикальной области уменьшение размеров очагов деструкции костных структур до 2/3 (рис.24).

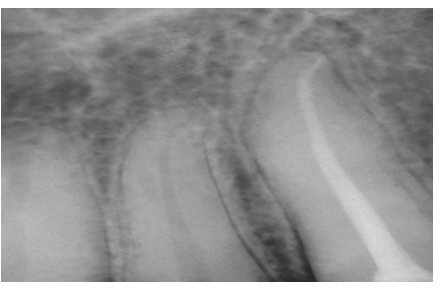

Рис.23. Наблюдение 2. Рентгенограмма больного А. через 3 месяца после лечения

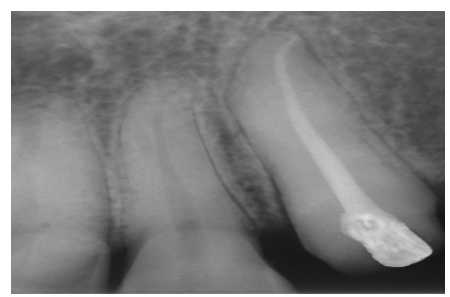

Рис.24. Наблюдение 2. Рентгенограмма больного А. через 6 месяцев после лечения

21.03.08г. Контрольное обследование через год после лечения. Жалоб нет. Объективно: 23 зуб под пломбой, слизистая оболочка бледно-розового цвета, перкуссия безболезненна. На рентгенограмме расширение периодонтальной щели 23 зуба (рис.25).

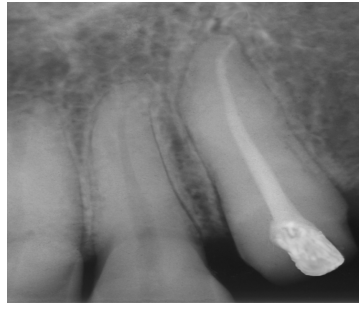

Рис. 25. Наблюдение 2. Рентгенограмма больного А. через год после лечения

\section{7 Сравнительная характеристика отдаленных результатов} лечения деструктивных форм ОХВП по данным рентгенограмм с применением периапикального индекса PAI

В данном разделе проведен сравнительный анализ результатов лечения деструктивных форм периодонтитов пятью лечебными комплексами в отдаленные сроки наблюдений (через 12 месяцев) с применением периапикального индекса PAI. 
Анализ результатов эндодонтического лечения различными лечебными комплексами представлен в таблицах 39 и 40.

Таблица 39

Сравнительная характеристика результатов лечения ОХВП под воздействием различных лечебных комплексов через 12 месяцев по данным рентгенограмм с применением индекса PAI

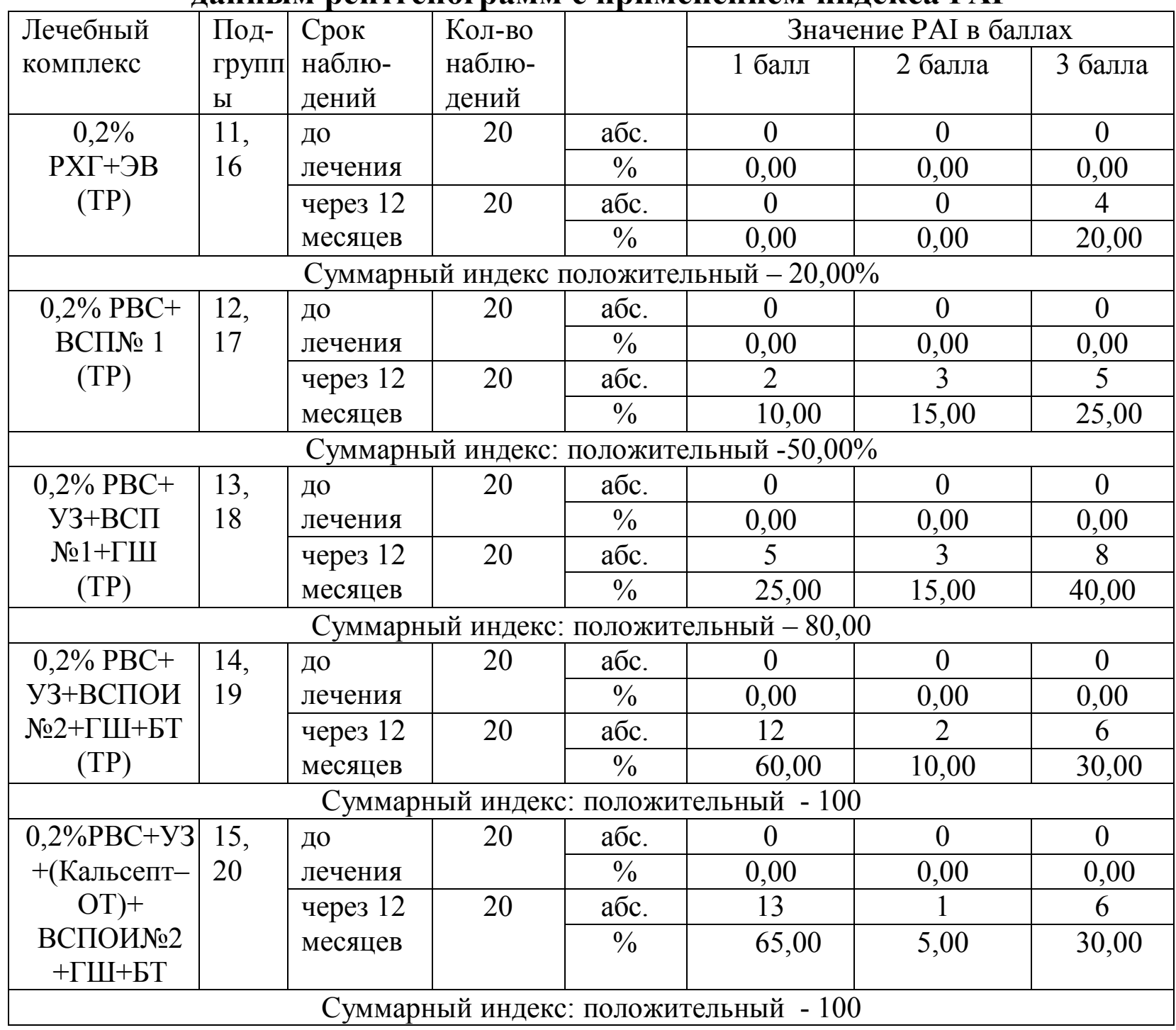

Согласно индексу PAI рентгенологические данные: полное, частичное восстановление костной ткани, а также расширение периодонтальной щели 1, 2 и 3 балла - трактуется как положительная динамика. При наличии на рентгенограммах изменений костных структур в апикальной области с нечеткими (4 балла) или четкими округлыми формами (гранулема) - 5 баллов - расценивается как отрицательная динамика. Сравнительная характеристика суммарных положительных, а также отрицательных значений позволили 
определить лучший лечебный комплекс при лечении ОХВП по данным рентгенограмм в отдаленные сроки наблюдений.

Таблица 40

\section{Сравнительная характеристика результатов лечения ОХВП под воздействием различных лечебных комплексов в отдаленные сроки}

(12 месяцев) по данным рентгенограмм с применением периапикального индекса PAI

\begin{tabular}{|c|c|c|c|c|c|c|}
\hline \multirow{2}{*}{$\begin{array}{l}\text { Лечебный } \\
\text { комплекс }\end{array}$} & \multirow{2}{*}{\begin{tabular}{|l|} 
Под- \\
группы
\end{tabular}} & \multirow{2}{*}{$\begin{array}{l}\text { Срок } \\
\text { наблю- } \\
\text { дений }\end{array}$} & \multirow{2}{*}{$\begin{array}{l}\text { Кол-во } \\
\text { наблю- } \\
\text { дений }\end{array}$} & & \multicolumn{2}{|c|}{ Значение PAI в баллах } \\
\hline & & & & & 4 & 5 \\
\hline \multirow{4}{*}{$\begin{array}{c}0,2 \% \text { РХГ }+Э B \\
\text { (ТP) }\end{array}$} & \multirow{4}{*}{$\begin{array}{l}11, \\
16\end{array}$} & \multirow{4}{*}{$\begin{array}{l}\text { до } \\
\text { лечения } \\
\text { через } 12 \\
\text { месяцев } \\
\end{array}$} & \multirow[t]{2}{*}{20} & абс. & 10 & 10 \\
\hline & & & & $\%$ & 50,00 & 50,00 \\
\hline & & & \multirow[t]{2}{*}{20} & абс & 6 & 10 \\
\hline & & & & $\%$ & 30,00 & 50,0 \\
\hline \multicolumn{7}{|c|}{ Суммарный индекс: отрицательный $-80,00 \%$} \\
\hline \multirow{4}{*}{$\begin{array}{c}0,2 \% \text { PBC+ } \\
\text { BCП № } 1 \\
\text { (ТР) }\end{array}$} & \multirow{4}{*}{$\begin{array}{l}12 \\
17\end{array}$} & \multirow{2}{*}{$\begin{array}{l}\text { до } \\
\text { лечения }\end{array}$} & \multirow[t]{2}{*}{20} & абс. & 10 & 10 \\
\hline & & & & $\%$ & 50,00 & 50,00 \\
\hline & & \multirow{2}{*}{$\begin{array}{l}\text { через } 12 \\
\text { месяцев }\end{array}$} & \multirow[t]{2}{*}{20} & абс & 5 & 5 \\
\hline & & & & $\%$ & 25,00 & 25,00 \\
\hline \multicolumn{7}{|c|}{ Суммарный индекс: отрицательный -50,00\% } \\
\hline \multirow{4}{*}{$\begin{array}{c}\text { 0,2\%РBC+У3+ } \\
\text { ВСП №1+ } \\
\text { ГШ (ТР) }\end{array}$} & \multirow{4}{*}{\begin{tabular}{|l}
13, \\
18
\end{tabular}} & \multirow{2}{*}{$\begin{array}{l}\text { до } \\
\text { лечения }\end{array}$} & \multirow[t]{2}{*}{20} & абс. & 10 & 10 \\
\hline & & & & $\%$ & 50,00 & 50,00 \\
\hline & & \multirow{2}{*}{$\begin{array}{l}\text { через } 12 \\
\text { месяцев }\end{array}$} & \multirow[t]{2}{*}{20} & абс. & 2 & 2 \\
\hline & & & & $\%$ & 10,00 & 10,00 \\
\hline \multicolumn{7}{|c|}{ Суммарный индекс: отрицательный -20,00\% } \\
\hline \multirow{4}{*}{$\begin{array}{c}0,2 \% \text { РВС+У3+ } \\
\text { ВСПОИ №2+ } \\
\text { ГШ+БТ (ТР) }\end{array}$} & \multirow{4}{*}{$\begin{array}{l}14 \\
19\end{array}$} & \multirow{4}{*}{$\begin{array}{l}\text { до } \\
\text { лечения } \\
\text { через } 12 \\
\text { месяцев } \\
\end{array}$} & \multirow[t]{2}{*}{20} & абс. & 10 & 10 \\
\hline & & & & $\%$ & 50,00 & 50,00 \\
\hline & & & \multirow[t]{2}{*}{20} & абс. & 0 & 0 \\
\hline & & & & $\%$ & 0,00 & 0,00 \\
\hline \multicolumn{7}{|c|}{ Суммарный индекс: отрицательный -0} \\
\hline \multirow{4}{*}{$\begin{array}{c}\text { 0,2\%РВС+У3+ } \\
\text { («Кальсепт» - } \\
\text { ОТ) +ВСПОИ №2 } \\
+ \text { +ГШ+БТ }\end{array}$} & \multirow{4}{*}{$\begin{array}{l}15 \\
20\end{array}$} & & 20 & абс. & 10 & 10 \\
\hline & & лечения & & $\%$ & 50,00 & 50,00 \\
\hline & & через 12 & 20 & абс. & 0 & 0 \\
\hline & & месяцев & & $\%$ & 0,00 & 0,00 \\
\hline
\end{tabular}

Установлено, что воздействие лечебного комплекса в 11, 16 подгруппах с различными формами ОХВП, где применялся лечебный комплекс, состоящий из медикаментозной обработки корневых каналов зубов 0,2\% раствором хлоргексидина и пломбирования их эвгедентом (традиционный метод), привело к положительной динамике в 20,00\% случаях $(2+3$ балла), которая выражалась в частичном восстановлении костной ткани в апикальном периодонте. Полного восстановления (1 балл) не произошло ни в 
одном случае. Отрицательная динамика $(4+5$ баллов) зарегистрирована в $80,00 \%$ случаев и сопровождалась сокращением отрицательного индекса PAI (80,00\% до лечения; 60,00\% - после) на 20,00\%.

При воздействии лечебным комплексом в 12, 17 подгруппах, состоящих из обработки корневых каналов $0,2 \%$ раствором велтосепта и пломбированием их велтосепт-пастой № 1 (традиционным методом), положительная динамика зарегистрирована в 50,00\% случаев, отрицательная динамика также у 50,00\% пациентов, сокращение индекса PAI c отрицательной динамикой произошло на 50,00\%.

В подгруппах 13, 18 с различными формами ОХВП (20 больных) лечение проводилось традиционным методом: кроме ирриганта 0,2\% раствора велтосепта корневые каналы обрабатывались ультразвуком внутриканально и пломбировались также велтосепт-пастой № 1 c гутаперчевыми штифтами.

Индивидуальный анализ динамики индекса PAI спустя 12 месяцев после лечения данным лечебным комплексом показал, что при использовании озвученного ирриганта (велтосепт) наблюдалась положительная динамика и составляла $80,00 \%$, тогда как отрицательная динамика $(4+5$ баллов) зарегистрирована в 20,00\% случаев и сопровождалась сокращением суммарного отрицательного индекса PAI на $80,00 \%$.

Для усиления остеогенеза в очагах деструкции в апикальном периодонте в 20 зубах с различными изменениями костных структур в лечебный комплекс включено: 0,2\% раствор велтосепта, ультразвук внутриканально для медикаментозной обработки системы макро- и микроканалов и пломбированием их велтосепт-пастой № 2 с гидроксиапатитом «Остеоиндуцин» с гуттаперчевыми штифтами.

Для снятия острых воспалительных явлений и активизации местного иммунитета применялся биостимулирующий низкоэнергетический свет «Bioptron» как до, так и после пломбирования корневых каналов. Этим 
комплексом лечение в 14, 19 подгруппах проводилось традиционным методом.

По данным периапикального индекса PAI под воздействием света «Bioptron» и гидроксиапатита «Остеоиндуцин» значительно улучшились репаративные процессы в апикальном периодонте: положительная динамика, спустя год после лечения данным комплексом, составляла 100\%, причем в $80 \%$ случаях установлено полное восстановление костных структур, а у 20,00\% пациентов очаги деструкции находились на стадии завершения построения костных балочек. Отрицательная динамика под воздействием данного лечебного комплекса отсутствовала.

В подгруппах 15, 20 с различными формами ОХВП проводился отсроченный метод лечения идентичным лечебным комплексом: после воздействия на микрофлору системы корневых каналов озвученным велтосептом, пломбирование их осуществлялось временным пломбировочным материалом «Кальсепт» с гидроксидом кальция под временную пломбу на срок 1 месяц, после чего проводилась замена временного материала на постоянный - велтосепт-пасту № 2 с гидроксиапатитом остеиндуцин с гуттаперчевыми штифтами. До и после пломбирования в лечебный комплекс включался свет «Bioptron».

Сравнительная характеристика рентгенологических данных спустя 12 месяцев после лечения различными лечебными комплексами представлена на рис. 26.

Установлено, что применение пролонгированного антисептического воздействия гидроокиси кальция путем применения «Кальсепта» на систему корневых каналов привело к улучшению отдаленных результатов и сопровождалось достоверно выраженным сокращением индекса PAI с отрицательной динамикой в $100 \%$ случаев. Положительная динамика выражалась в $65,00 \%$ случаев полным восстановлением очагов деструкции костных структур в периапикальной области, а в 35,00\% очаги деструкции находились на стадии построения новых структур. 


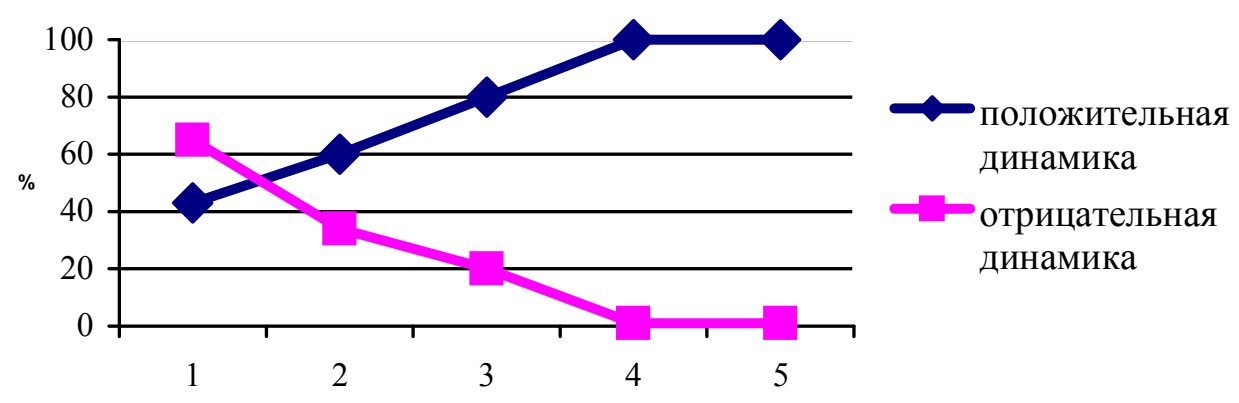

$1-0,2 \%$ РХГ+ЭВ (традиционный метод)

2 - 0,2\% РВС+ВСП № 1 (традиционный метод)

3 - 0,2\% РВС+У3+ВСП №1+ГШ (традиционный метод)

4 - 0,2\% РВС+УЗ+ ВСПОИ№2+ГШ+БТ (традиционный метод)

5 - 0,2\% РВС+УЗ+(«Кальсепт» - отсроченный метод) +ВСПОИ№2 +ГШ+БТ

Рис. 26. Сравнительная оценка воздействия различных лечебных комплексов на репаративные процессы в апикальном периодонте при лечении ОХВП по данным рентгенограмм в отдаленные сроки наблюдений (через 12 месяцев)

Таким образом, по данным таблицы 32 и рис.26 лучшим изучаемым лечебным комплексом был комплекс с введением в эндодонтический пломбировочный материал ультрадисперсного «Остеоиндуцина», с предварительной медикаментозной обработкой корневых каналов зубов озвученным раствором «Велтосепта», с применением светотерапии лампы «Bioptron» как традиционным, так и отсроченным методами. Установлено, что применение данного комплекса привело к $100 \%$ суммарной положительной динамике по периапикальному индексу PAI при лечении ОХВП.

\section{ГЛАВА 5. ЗАКЛЮЧЕНИЕ}

На сегодняшний день заболевания периодонта занимают третье место по частоте обращаемости после кариеса и пульпита, и являются одной из самых актуальных проблем в терапевтической стоматологии.

Среди многих причин, вызывающих заболевания периодонта, одной из первых отводится микроорганизмам и их токсинам. В результате проникновения микроорганизмов и их токсинов в периодонт развивается острая воспалительная реакция, усиливающаяся за счет образования биологически активных веществ, повышающая сосудистую проницаемость, 
экссудацию, нарушение кровообращения и в результате деструкцию тканей периодонта. Традиционные методы лечения острых и обострившихся форм хронических периодонтитов направлены на устранение микробного фактора (антимикробные и противовоспалительные средства).

Несмотря на значительное усовершенствование эндодонтического инструментария и методик обработки корневых каналов, на сегодняшний день невозможно обеспечить полную дезинфекцию данными методами из-за сложной их внутренней анатомии, сложностью доступа традиционных инструментов и ирригационных растворов к бактериям, укрывшимся в труднодоступных участках корневых каналов. Необходим комплексный подход лечения периодонтитов с использованием инструментальных, медикаментозных, физических факторов, позволяющих активно влиять на основные звенья патогенеза околоверхушечного процесса, устранения воспалительно-деструктивного очага в периодонте.

Нами принято решение изучить эффективность комплекса лечебных воздействий при лечении острых и обострившихся хронических верхушечных периодонтитов, состоящего из антисептика «Велтосепт» в сочетании с воздействием на микрофлору системы микроканалов ультразвука, принципиально нового лечения поляризованным светом лампы «Bioptron», а также нанодисперсного гидроксиапатита «Остеоиндуцин» в составе эндодонтического пломбировочного материала. Лампа «Bioptron» излучает полихроматический свет в волновом диапазоне от 480 до 3400 нм, длина его волны выше чем у УФ-излучения, а энергетический диапазон ниже, чем у лазерного луча, поэтому он безвреден для организма. Свет, излучаемый лампой «Bioptron» линейно поляризован и движется в одном направлении в параллельных плоскостях, проникая на глубину 2,5-3 см, стимулирует регенеративные процессы, нормализует кровообращение, ликвидирует воспаление и отек тканей, ускоряет заживление ран, стимулирует обменные и иммунные системы, обладает обезболивающим 
эффектом. Однако применение поляризованного света в стоматологии изучено недостаточно.

Уникальным многокомпонентным воздействием на внутреннюю среду корневых макро- и микроканалов является ультразвук (УЗ). Ультразвук создает механические колебания жидкой среды в канале с антисептиком, что приводит к сжатию и растяжению жидкой среды. В фазе растяжения происходит разрыв межмолекулярных сил сцепления и возникновение микрополостей - кавитация. Образующиеся при кавитации пузырьки в фазе сжатия мгновенно исчезают, а возникающие при этом ударные волны, электрические заряды и высокие локальные температуры, инициируют специфические звуко-химические реакции в озвученной среде, где возникают мелко- и среднемасштабные течения и турбуляции, которые существенно ускоряют процессы растворения органических соединений. Кавитация и акустический поток оказывают повреждающее действие на клеточные оболочки бактерий. Активный кислород, образующийся в процессе ультразвуковой обработки является антагонистом анаэробов, тормозя рост популяций этих микроорганизмов. Таким образом, ультразвуковые колебания, создавая эффект кавитации, разрушают бактерии, механически очищают дентинные трубочки с наибольшей эффективностью. В этом случае не играет никакой роли ни форма канала, ни его диаметр, ни длина.

В качестве дезинфектанта в комплекс лечебных воздействий включено средство с запатентованной комбинацией активных веществ широко спектра микробиологической активности «Велтосепт» (Оренбург, Россия). Он широко применяется в хирургии, терапии, дерматологии, педиатрии, однако, применение его в стоматологии мало изучено, хотя препарат активен даже в отношении ВИЧ-инфекции и гепатита А. По параметрам острой токсичности по ГОСТ 12.1.007-76 средство «Велтосепт» относится к 4-му классу малоопасных соединений при введении в желудок и нанесении на кожу. Средство не обладает местнораздражающим, кожно-резорбтивным и сенсибилизирующим действием. Применяется для обработки кожи 
операционного и инъекционного полей, рук хирургов и работников детских учреждений, стоматологического инструментария.

Работа выполнялась в два этапа: экспериментальный (микробиологическое исследование) и клинический (клиникорентгенологическое и иммунологическое исследование). На первом этапе изучалось влияние велтосепта на штаммы различных микроорганизмов, на плотных питательных средах и суспензионным методом определялась минимальная подавляющая концентрация в отношении представителей микрофлоры полости рта, изучался микробный пейзаж корневых каналов зубов у больных с острыми явлениями в периодонте и санация корневых каналов раствором велтосепта с ультразвуком и светом «Bioptron» и без них. Проведенные эксперименты позволили показать, что велтосепт обладает выраженной антимикробной активностью в отношении микрофлоры ротовой полости (стафилококки, стрептококки, кишечная палочка), активность препарата зависит от вида микробного агента и концентрации антисептика. Минимальная подавляющая концентрации - МПК препарата составляет 0,2\%. Она обеспечивает бактерицидный эффект в отношении всех изучаемых штаммов микроорганизмов, независимо от их концентрации. В результате проведенных исследований был определен также микробный пейзаж с острыми явлениями в периодонте. Среди микроорганизмов аэробная микрофлора составляла 45,90\%, анаэробная - 54,10\%, осуществлена идентификация изолированных культур по морфологии микробной клетки: кокки - 62,20\%, палочки - 37,80\%.

Для сравнительной оценки эффективности санации корневых каналов зубов были использованы три подхода: изолированное применение антисептика при МПК 0,2\%; комплексное воздействие велтосепта с ультразвуком; велтосепта, ультразвука (внутриканально) и света «Bioptron» (чрезкожно). Проведенные исследования показали, что в результате клинической апробации использования ирриганта «Велтосепт» различной концентрации $(0,2 \%, 0,1 \%, 0,05 \%)$ как изолировано $(0,2 \%)$, так и в 
комплексной терапии (ультразвуком и светом «Bioptron»), является достоверно доказанным, экспериментально подтвержденным на клиническом материале применение $0,2 \%$ раствора «Велтосепта». В комплексе с физическими факторами санация корневых каналов зубов усиливается: с ультразвуком в концентрации $0,1 \%$, с У3 и светом «Bioptron» активность препарата достигнута в 0,05\% концентрации.

Объектами клинических наблюдений послужили 200 пациентов (116 женщин и 84 мужчины) в возрасте от 18 до 40 лет, обратившихся по поводу лечения острых и обострившихся хронических форм верхушечных периодонтитов. Из них были сформированы четыре групп по 50 больных: с острыми явлениями в стадии интоксикации (ОВПСИ) - первая группа; с острыми явлениями в стадии экссудации (ОВПСЭ) - 2 группа и с различными формами обострившихся верхушечных периодонтитов: гранулирующего (ОХВГрП) - третья группа; гранулематозного (ОХВГП) - четвертая группа.

В зависимости от комплекса лечебных воздействий больные каждой группы были разделены на пять подгрупп, общее количество больных было представлено 20 подгруппами. У больных 1, 6, 11 и 16 подгрупп с различными формами верхушечного периодонтита лечебный комплекс состоял из медикаментозной обработки корневых каналов 0,2\% раствором хлоргексидина (РХГ) и пломбирования их эвгедентом (ЭВ) традиционным методом. В подгруппах 2, 7, 12, 17 с различными формами острых и обострившихся хронических верхушечных периодонтитов лечебный комплекс состоял из медикаментозного воздействия на микрофлору макро- и микроканалов зубов дезинфектантом «Велтосепт», каналы пломбировались предложенной нами велтосепт-пастой № 1 традиционным методом. Пациентам 3, 8, 13 и 18 подгруппы с различными формами верхушечных периодонтитов медикаментозную обработку проводили 0,2\% раствором велтосепта и ультразвуком внутриканально, корневые каналы пломбировали велтосепт-пастой № 1 с гуттаперчевыми штифтами традиционным методом. В подгруппах 4, 9, 14, 19 с деструктивными формами обострившихся 
хронических верхушечных периодонтитов лечебный комплекс состоял из медикаментозной обработки системы макро- и микроканалов и периодонта озвученным раствором 0,2\% велтосепта и воздействия света «Вioptron», каналы пломбировались велтосепт-пастой с гидроксиапатитом «Остеоиндуцин» гуттаперчевыми штифтами традиционным методом. В подгруппах 5, 10, 15, 20 с ОВП и ОХВП применялся отсроченный метод лечения комплексом, состоящим из медикаментозной обработки корневых каналов 0,2\% раствором «Велтосепта» и ультразвуком внутриканально в комплексе с воздействием биостимулирующего света «Bioptron» чрезкожно. Корневые каналы пломбировались временно материалом «Кальсепт» с гидроксидом кальция, постоянно - велтосепт-пастой № 2 с гидроксиапатитом «Остеоиндуцин» и гуттаперчевыми штифтами.

Эффективность различных способов лечения острых и обострившихся процессов в периодонте и влияние их на репаративные процессы остеосинтеза определялись путем сравнительного анализа клинических и рентгенологических данных. В ближайшие (3-5 дней) и отдаленные (через 3, 6, 12 месяцев) сроки наблюдений после пломбирования корневых каналов. Ближайшие результаты с благоприятным клиническим течением считались те, когда больные не предъявляли жалоб спустя сутки после лечения.

При наличии жалоб на ноющую боль, боль при накусывании на причинный зуб, наличие гиперемии, отека переходной складки слизистой оболочки полости рта, болезненность при пальпации спустя сутки после окончания лечения - такие результаты трактовались как неблагоприятные. Степень заполнения корневых каналов зубов оценивалась по данным рентгенограмм, которые выполнялись сразу после пломбирования.

B работе применялся ультразвук аппарата «Amdent US 30 D» в режиме эндодонтии, частота 24-28 кГц, обеспечивающий полноценную санацию корневых каналов зубов в среде ирриганта «Велтосепт» за счет проникновения в труднодоступные места (плохо проходимые каналы и микроканалы), оказывая антимикробное, противовирусное, фунгицидное, 
антиэкссудативное, стимулирующее действие. Данные процедуры проводились внутриканально.

Для ликвидации острого воспалительного процесса и болевого синдрома, улучшения функционального состояния, профилактики развития деструктивных процессов использовали поляризованный (степень поляризации 95\%), полихроматичный, низкочастотный свет «Bioptron», который в отличие от лазерного света, содержащего всего лишь одну длину волны, обладает широким спектральным составом с длиной волны 480-3400 нм с удельной мощностью $40 \mathrm{MBT} / \mathrm{cm}^{2}$ с экспозицией от 2 до 10 минут. Данные процедуры проводились чрезкожно в проекции верхушек корней леченого зуба после эвакуации распада и экссудации из каналов, начиная со второго посещения. Продолжительность курса лечения определяли индивидуально в зависимости от формы и размера патологического очага.

Анализ клинических показателей динамики воспалительного процесса в периапикальных тканях зубов в ближайшие сроки наблюдений показал, что в тех подгруппах, где для медикаментозной обработки корневых каналов использовался 0,2\% раствор «Велтосепта», явления воспаления купировались чаще по сравнению с теми подгруппами, где применялся 0,2\% раствор хлоргексидина, как при лечении ОВП, так и ОХВП. В подгруппах с различными формами периодонтитов, где для санации корневых каналов был использован ультразвук с антисептиком «Велтосепт», купирование воспалительных явлений в периодонте зарегистрировано в большем проценте случаев, по сравнению с теми данными, где санация проводилась изолировано только $0,2 \%$ раствором «Велтосепта» или $0,2 \%$ раствором хлоргексидина.

Сравнительная оценка эффективности лечения ОВП и ОХВП с применением различных лечебных комплексов показала, что воспалительный процесс значительно чаще и быстрее купировался в подгруппах с применением света «Bioptron» в сочетании с обработкой корневых каналов ирригантом «Велтосепт» с ультразвуком и без него. Асимметрия лица, 
болезненность регионарных лимфатических узлов, гиперемия и отечность мягких тканей в этих подгруппах устранялись в 2-2,5 раза быстрее. Болезненная перкуторная реакция как причинных, так и соседних зубов прекращалась в 1,5-2 раза активнее. Явления экссудации из корневых каналов ликвидировались значительно быстрее после воздействия света «Bioptron». После купирования острых явлений в периодонте корневые каналы пломбировались различными пломбировочными материалами. Нами предложено две эндодонтические пасты: велтосепт-паста № 1 (оксид цинка 0,6 г, сульфат бария 0,2 г, велтосепт 0,1 мл, масло персиковое 0,3 мл); велтосепт-паста № 2 с нанодисперсным гидроксиапатитом «Остеоиндуцин» (оксид цинка 0,6 г, сульфат бария 0,2 г, велтосепт 0,1 мл, масло персиковое 0,3 мл, остеоиндуцин 0,2 г).

Остеоиндуцин - новейшая разработка нанотехнологий в стоматологии остеопластический материал на основе аморфного нанодисперсного резорбируемого гидроксиапатита кальция с диаметром гранул 1 мкм. Остеоиндуцин применяется в качестве остеопластического материала, активизирующего регенерацию костной ткани. Анализ динамики воспалительного процесса в периодонте после пломбирования корневых каналов под воздействием различных пломбировочных материалов в сочетании с дезинфектантами и физическими методами показал, что наибольший процент осложнений был отмечен в подгруппах с различными формами периодонтитов, где корневые каналы пломбировались эвгедентом (от 50 до 90\%). Наилучшие результаты установлены в подгруппах, где для обтурации корневых каналов применялась велтосепт-паста № 2 с остеоиндуцином в комплексе с санацией корневых каналов озвученным «Велтосептом» и воздействием света «Bioptron» как традиционным, так и отсроченным методами лечения, осложнений не отмечалось. Клинические результаты применения данного комплекса воздействий свидетельствуют о положительном действии велтосепт-пасты с остеоиндуцином в сочетании со 
светом «Bioptron» на патологический очаг воспаления в периодонте в ближайшие сроки наблюдений.

До и после лечения различных форм верхушечных периодонтитов изучали цитохимические показатели материала десневого желобка. Анализ полученных данных показал, что в результате развития острого патологического процесса клеточный состав содержимого десневого желобка резко изменялся, что характеризовалось значительным увеличением содержания нейтрофилов, в то же время отмечалось снижение количества эпителиальных клеток и лимфоцитов. Развитие острых явлений сопровождалось снижением активности МПО и КБ, увеличением активности щелочной и кислой фосфатаз. Проводимое комплексное лечение предложенным комплексом с применением света «Bioptron» спустя 30 суток после лечения показало, что показатели активности МПО, КФ, ЩФ и количество КБ в нейтрофилах периферической крови соответствовали индивидуальной норме.

Отдаленные результаты лечения оценивались на основании клиникорентгенологических данных спустя три, шесть и двенадцать месяцев после пломбирования корневых каналов при различных формах верхушечных периодонтитов с применением периапикального индекса PAI. Согласно PAI полное восстановление костной ткани расценивается 1 (одним) баллом; частичное - 2 баллами; расширение периодонтальной щели - 3 балла; изменение костных структур с нечеткими границами - 4 балла; с четкими овальными (гранулема) - 5 баллов. Суммарные значения 1, 2, 3 баллов трактуется как положительная динамика; 4,5 баллов - отрицательная динамика. Сравнивая положительную и отрицательную динамику при лечении ОХВП по данным рентгенограмм различными лечебными комплексами, установлен лучший из них. Спустя 12 месяцев, при воздействии лечебным комплексом (традиционный метод) с 0,2\% раствора хлоргексидина + эвгедента - положительная динамика установлена в 20,00\% 
случаев; отрицательная - в 80,00\%, что сопровождалось сокращением суммарного отрицательного индекса PAI на 20,00\%.

Лечебный комплекс (традиционный метод) с 0,2\% раствором велтосепта и велтосепт-пастой № 1 привел к положительной динамике в 50,00\% случаев, отрицательной также у $50,00 \%$ пациентов, сокращение суммарной отрицательной динамики и индекса произошло на 50,00\%. Под воздействием лечебного комплекса: $\quad 0,2 \%$ раствор велтосепта, ультразвука (внутриканально) + велтосепт-паста № $1+$ ГШ, положительная динамика зарегистрирована в $80,00 \%$ случаев, отрицательная - в 20,00\% пациентов и сопровождалась сокращением суммарного отрицательной динамики по индексу PAI на 80,00\%.

В работе применялся лечебный комплекс, состоящий из 0,2\% раствора велтосепта и ультразвука внутриканально, пломбировочной пасты ВСПОИ №2 для усиления остеосинтеза в апикальном периодонте, а также включающий в себя применение биостимулирующего света «Bioptron» чрезкожно до и после пломбирования корневых каналов для купирования острых явлений в периодонте и активизации местного иммунитета. Лечение данным лечебным комплексом проводилось традиционным методом. По данным периапикального индекса PAI под воздействием гидроксиапатита «Остеоиндуцин» и полихроматичного света «Bioptron» значительно улучшились репаративные процессы в апикальном периодонте: положительная динамика спустя год после лечения данным комплексом, составляла в $60,00 \%$ случаев полное восстановление костных структур, а у 40,00\% пациентов очаги деструкции находились на стадии завершения построения костных балочек. Отрицательная динамика под воздействием данного лечебного комплекса отсутствовала. У 20 пациентов с различными формами ОХВП проводился отсроченный метод лечения: после воздействия озвученным раствором «Велтосепта» на микрофлору системы корневых каналов, пломбирование их осуществлялось временным стерильным пломбировочным материалом «Кальсепт» с гидроксидом кальция под 
временную пломбу на срок - 1 месяц, после чего проводилась замена временного материала на постоянный - велтосепт-пасту № 2 с нанодисперсным гидроксиапатитом «Остеоиндуцин» с гуттаперчевыми штифтами. До и после пломбирования каналов включался в лечебный комплекс свет «Bioptron».

Установлено, что применение пролонгированного антисептического воздействия гидроксида кальция материала «Кальсепт» на систему корневых каналов привело к улучшению отдаленных результатов лечения деструктивных форм апикальных периодонтитов и сопровождалось достоверно выраженным сокращением индекса PAI с отрицательной динамикой в 100\% случаев. Положительная динамика выражалась в 65,00\% случаев полным восстановлением очагов деструкции костных структур в периапикальной области, а в 35,00\% - очаги деструкции находились на стадии завершения построения новых костных структур.

Новейшее антимикробное средство «Велтосепт» с широчайшим спектром антимикробной активности под воздействием кавитации ультразвука, способное перемещаться в микроканалы дентина и периодонт, обеспечило полноценную санацию системы каналов. Воздействие поляризованного света «Віoptron» до и после пломбирования корневых каналов способствовало повышению уровня защитных компонентов иммунной системы и обменных процессов организма, ингибируя процессы альтерации, экссудации, пролиферации и в результате - отсутствие осложнений после пломбирования корневых каналов зубов.

Паста «велтосепт - остеоиндуцин», содержащая высокочистый, ультрадисперсный, резорбируемый биосовместимый гидроксиапатит кальция, способствовала возможности включения гиалуроновой кислоты в процесс стимуляции роста клеток, и как следствие, - восстановлению репаративного остеогенеза.

Таким образом, сравнивая пять способов лечения ОВП и ОХВП, лучшим лечебным комплексом по клинико-рентгенологическим данным спустя год 
после лечения, был комплекс с дополнительным введением в эндодонтический пломбировочный материал ультрадисперсного гидроксиапатита «Остеоиндуцин» и физических методов воздействия ультразвука внутриканально и поляризованного света «Bioptron» чрезкожно как традиционным, так и отсроченным методами.

Этот лечебный комплекс позволил положительно повлиять на все патогенетические звенья при лечении обострившихся хронических верхушечных периодонтитов с положительной динамикой в 100\% случаев.

Проведенные экспериментальные, клинико-рентгенологические и иммунологические исследования позволили нам рекомендовать новый способ лечения острых и обострившихся хронических верхушечных периодонтитов с применением лечебного комплекса, состоящего из 0,2\% раствора «Велтосепта», ультразвука (внутриканально), света «Bioptron» (чрезкожно) и нанодисперсного гидроксиапатита «Остеоиндуцин» в составе «велтосепт-остеоиндуцин» пасты.

\section{ВЫВОДЫ}

1. Экспериментальные микробиологические исследования позволили установить высокую антибактериальную активность антисептика «Велтосепт» в озвученной среде на микрофлору макро- и микроканалов зубов при различных формах ОВП и ОХВП. МПК велтосепта в отношении представителей различных видов микрофлоры корневых каналов зубов равна $0,2 \%$.

2. Применение эндодонтической пасты, содержащей велтосепт и ультрадисперсный гидроксиапатит «Остеоиндуцин», при лечении деструктивных форм верхушечных периодонтитов способствовало усилению репаративных процессов в периодонте спустя год после лечения

3. Применение поляризованного, полихроматичного, низкочастотного, биостимулирующего света «Bioptron» до и после пломбирования корневых каналов способствовало купированию воспалительного процесса в 
апикальном периодонте при лечении различных форм ОВП и ОХВП. Установлено на клиническом материале, что острые процессы в периодонте отражаются на ферментативной активности полиморфноядерных лейкоцитов и на клеточном составе содержимого десневого желобка, которые нормализуются под воздействием светотерапии.

4. Клинико-рентгенологические изменения верхушечного периодонта при ОВП и ОХВП оценивались по индексу РАI, что выражалось в 60,00\% и $65,00 \%$ случаев полным восстановлением костных структур ТР и ОТ; в $40,00 \%$ и $35,00 \%$ случаев соответственно очаги деструкции находились на стадии построения новых костных структур.

5. На основании проведенных экспериментальных и клинических исследований разработан, апробирован и внедрен в стоматологическую практику новый модифицированный способ лечения острых и хронических обострившихся верхушечных периодонтитов с применением антисептика «Велтосепт» и УЗ внутриканального для санации системы корневых каналов и временного материала «Кальсепт», с последующим пломбированием с использованием «велтосепт-пасты» с нанодисперсным гидроксиапатитом «Остеоиндуцин» в комплексе с биостимулирующим светом «Bioptron» чрезкожно для купирования острого процесса и стимуляции местного иммунитета в периодонте.

\section{ПРАКТИЧЕСКИЕ РЕКОМЕНДАЦИИ}

1. При острых явлениях в периодонте в первое посещение под анестезией провести инструментальную и медикаментозную обработку корневых каналов 0,2\% РВС и УЗ внутриканально, чрезкожно провести сеанс светом «Bioptron» в проекции верхушек корней леченого зуба при отсутствии экссудации из корневых каналов.

2. Для пломбирования корневых каналов при лечении всех форм ОВП и ОХВП после прекращения экссудации из корневых каналов рекомендуется использовать пасту следующего состава: оксид цинка 0,6 г, велтосепт 0,1 мл, 
масло персиковое 0,3 мл, остеоиндуцин 0,2 г и пломбировать с применением гуттаперчевых штифтов до апикального отверстия, в комплексе со светом «Bioptron», который использовался во второе посещение после прекращения оттока экссудата.

3. При лечении ОТ рекомендуется после воздействия на микрофлору корневых каналов $\mathrm{PBC}$ в озвученной среде, каналы запломбировать временным пломбировочным материалом «Кальсепт» с гидроксидом кальция сроком на один месяц, после чего заменить временный материал на постоянную ВСПОИ №2 с ГШ в комплексе со светом «Bioptron». 